\title{
TOWARDS AN INTELLECTUAL PROPERTY BARGAINING THEORY: THE POST-WTO ERA
}

\author{
DANIEL BENOLIEL* AND BRUNO SALAMA**
}

\begin{abstract}
This Article proposes a positive bargaining theory for intellectual property-based technologies in the post-World Trade Organization ("WTO") era. It focuses on negotiations between patentsensitive industries and developing countries over legal endowments and access conditions in an archetypical patent-sensitive industry, namely the pharmaceutical industry. The ability of developing countries to issue, or threaten to issue, compulsory licenses over pharmaceutical products serves as a working example.

This Article's analysis of the bargaining power possessed by developing countries combines a conventional assessment of market size with a qualitative analysis that highlights the effects of these countries' propensity to innovate. The ensuing bargaining

* Assistant Professor, Faculty of Law at the University of Haifa. For further information, please contact: dbenolie@law.haifa.ac.il.

** Professor of Law, Fundação Getúlio Vargas Law School, São Paulo, Brazil. For further information, please contact: bruno.salama@fgv.br.

This Article was selected for presentation at the 2009 Harvard-Stanford Junior Faculty Forum, and given the Microsoft Research Award for Scholarship on Law and Economics for an outstanding research paper presented at the 2009 Annual Meeting of the Latin American and Caribbean Law \& Economics Association ("ALACDE"). This Article has been presented at conferences and workshops at Yale Law School, Harvard Law School, Hebrew University Faculty of Law, Haifa University Faculty of Law, University of São Paulo School of Economics, and Fundação Getúlio Vargas Law School. The Authors wish to thank Robert Cooter, Yochai Benkler, Neil Netanel, Peter Yu, Amy Kapczynski, Ravi Ramamurti, Caio Mario da Silva Pereira, Michael Birnhak, Eran Bareket, Oscar Vilhena Vieira, and Luciana Yeung for their comments and advice. The Authors would also like to thank the participants of all of the above conferences for their helpful comments. For their research assistantship, the authors are thankful to Priscilla César, Gabriel Pinto, Rotem Medzini, and Leor Sapir. We gratefully acknowledge financial support from the Law School of the Fundação Getúlio Vargas in São Paulo. Any inaccuracies are our responsibility.
\end{abstract}


[Vol. 32:1

situation yields numerous insights, the primary ones being as follows: First, innovation in intellectual property-based technologies, such as within the fields of pharmaceuticals, software, information communication technologies ("ICTs"), and plant genetics, creates a paradoxical effect within the group of innovative Newly Industrialized Countries ("NICs"). The paradox is based on the notion that innovation weakens, rather than boosts, the countries' bargaining power vis-à-vis the prospect of bargaining retaliations. This is conspicuously the case of the prospect of issuing compulsory licenses over pharmaceutical patents.

Second, the resulting bargaining dynamic deemphasizes the practical significance of the Least-Developed-Country ("LDC") carve-out contained in the Trade-Related Aspects of Intellectual Property Rights ("TRIPS") and other WTO agreements. Specifical$l y$, it is argued that distributive justice policies contained in TRIPS should be geared toward a broader group of weak developing countries extending beyond the group of LDCs. This theory points out a tentative threefold typology of developing countries defined based on their bargaining power. Accordingly, developing countries are modeled as HBPs, MBPs, and LBPs depending on whether they are relatively high, medium, or low-bargaining power countries, respectively.

In its conclusion, this Article contends, based on the model presented, that strong protection of intellectual property rights could have significant negative allocation consequences for developing countries. Such is the case without contributing to-and even impeding-their technological development. Arguably, the HBPMBP-LBP underlying developmental inequality shifts the optimal balance between static and dynamic efficiencies. In that sense, TRIPS may prove ineffective in promoting dynamic long-term innovation policies for developing countries.

TABLE OF CONTENTS

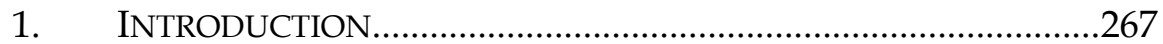

2. THE POST-WTO IPR BARGAINING SITUATION ............................273

2.1. Overview ..............................................................................2.273

2.2. Bargaining Transition in the Post-WTO Era .......................275

2.2.1. Development Inequality Principle......................275

2.2.2. The Case of Bargaining Power in Pharmaceutical Patents 
2.2.2.1. Outside Option: Instrumentality of

Patent Compulsory Licenses

2.2.2.2. Inside Options: National Opportunism Within TRIPS

2.2.2.3. Market Power: Competition and Subs-

titutes

3. THE INNOVATION BENT OVER THE

BARGAINING COST STRUCTURE .................................................309

3.1. Overview

3.2. The HBP Model: A Single-Sanction Cost Structure

3.2.1. Introduction 312

3.2.2. The HBP-MBP Regional Thresholds 314 3.2.2.1. Brazil/South America 314

3.2.2.2. Thailand/Asia 319

3.2.2.3. South Africa/Africa 323

3.3. The MBP Model: A Dual-Sanction Cost Structure ...............326

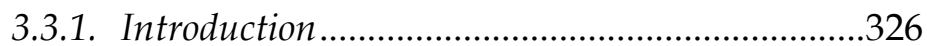

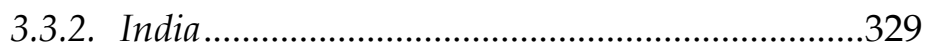

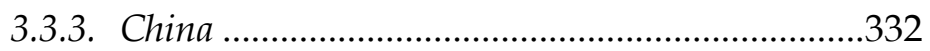

3.4. The LBP Model: A Positional Bargaining Situation .............336

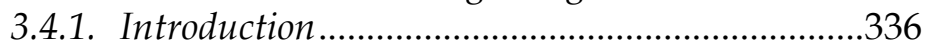

3.4.2. Least Developed Countries and Beyond ...............338

3.4.3. Positional Bargaining Over TRIPS.....................343

3.4.3.1. Outside Option ........................................349

3.4.3.2. Inside Option ............................................353

3.4.3.3. Market Power ...........................................361

4. CONCLUSION 364

\section{INTRODUCTION}

This Article proposes a positive bargaining theory for intellectual property-based technologies in the post-World Trade Organization ("WTO") era. It focuses on negotiations over legal endowments and access conditions in an archetypical patent-sensitive industry, namely the pharmaceuticals industry. The ability of developing countries to issue, or threaten to issue, compulsory licenses over pharmaceuticals serves as a working example. A compulsory license forces the patentee to license the patent to the issuing government, thus permitting local production or importation of generic copies of the drug for payment of below-market compensation to the patentee. 
The WTO-sponsored TRIPS agreement contains numerous loopholes that provide plasticity for national governments to respond to political exigencies. ${ }^{1}$ In reality, these loopholes consist of flexibilities and safeguards that allow WTO members to minimize the potential negative effects of intellectual property protection. ${ }^{2}$ From among such loopholes, the authorization for WTO members to compulsorily license patents is of particular relevance. While TRIPS mandates that all WTO members enact and enforce TRIPScompliant patent laws in their territories, in limited circumstances it also allows national governments to force the patentee to grant use of the patent for payment of below-market royalties. ${ }^{3}$ Yet, the issuance of a compulsory license is largely dependent upon whether the country possesses sufficient bargaining power, notwithstanding the existence of legal loophole.

In the post-WTO era, it is commonly thought that the General Agreement on Tariff and Trade ("GATT")/WTO system has proven increasingly subject to legal, rather than political, control. ${ }^{4}$ Indeed, the Uruguay Round of negotiations that ended in 1994 "legalized" the international negotiations. ${ }^{5}$ One of the alleged

1 See Judith Goldstein et al., Introduction: Legalization and World Politics, 54 INT'L ORG. 385, 392 (2000) (exploring the "variation in the use and consequences of law in international politics").

2 See Robert Weissman, A Long, Strange TRIPS: The Pharmaceutical Industry Drive to Harmonize Global Intellectual Property Rules, and the Remaining WTO Legal Alternatives Available to Third World Countries, 17 U. PA. J. INT'L ECON. L. 1079, 1096 (1996) (describing how intellectual property became a central component of the free trade agenda and how this affects the Third World).

3 See Antony Taubman, Rethinking TRIPS: 'Adequate Remuneration' For NonVoluntary Patent Licensing, 11 J. INT'L ECON. L. 927 passim (2008) (exploring how to interpret amendments to the TRIPS Agreement in light of WTO dispute resolution laws and the broader legal framework, which includes human rights and investment law).

4 See Peter M. Gerhart \& Archana Seema Kella, Power and Preferences: Developing Countries and the Role of the WTO Appellate Body, 30 N.C. J. INT'L L. \& COM. REG. $515,562-72$ (2005) (noting that the WTO's appellate body has taken on a judicial posture while remaining aware of sensitive political issues). See generally JOHN H. JACKSON, THE WORLD TRADING SYSTEM 109-11 (2nd ed. 1997) (comparing the new rule-based system of the WTO after the Uruguay Round with the prior poweroriented system of GATT).

5 See Kenneth W. Abbott et al., The Concept of Legalization, 54(3) INT'L ORG. 401, 409 (2000) (exploring the three components of legalization, obligation, precision, and delegation, their variability, and combination). 
achievements of the Uruguay Round was that it promoted a reduction in the power held by developed countries. ${ }^{6}$ That assertion is often grounded on a set of treaty provisions that were purportedly designed to limit the use of power, both in the context of dispute resolution and more broadly in trade negotiations. ${ }^{7}$ The establishment of legal rules, such as those set forth for instance under the TRIPS Agreement, begs the use of legal discourse. ${ }^{8}$ Consequently, even where disagreement exists over the exact interpretation of a rule, negotiations can no longer be carried out exclusively in terms of interests and power. ${ }^{9}$ However, as this Article demonstrates, in the context of bargaining between patent-sensitive industries and developing countries, the demise of the power-based system is in many ways unlikely. As is to be argued, the basis on which the relevant law is made is best understood through a power-based system. ${ }^{10}$ This reality explains the usefulness of applying bargaining theory as an analytical tool. ${ }^{11}$

6 In this Article, the term "developed countries" includes the United States, Canada, European Union countries, Cyprus, Malta, Slovenia, Israel, Japan, South Korea, Hong Kong, Singapore, Taiwan, Australia, and New Zealand. See Database-WEO Groups and Aggregates Information, INT'L MONETARY FUND, WORLD ECONOMIC OUTLOOK, available at http://www.imf.org/external/pubs/ft /weo/2008/02/weodata/groups.htm\#ae (last visited Nov. 4, 2010) (depicting the various "Advanced Economies").

7 See Agreement on Safeguards, Apr. 15, 1994, art. 11, available at http://www.wto.org/english/res_e/booksp_e/analytic_index_e/safeguards_02 _e.htm (last visited Oct. 11, 2010) (providing the text of the Prohibition and Elimination of Certain Measures, which prohibits unilateral action as it relates to trade relations). See generally Understanding on Rules and Procedures Governing the Settlement of Disputes, Dec. 15, 1993, 33 I.L.M. 112 (1994) [hereinafter WTO, Understanding] (describing channeling disputes between countries that concern WTO obligations into the dispute settlement procedures).

8 Abbott, supra note 5 .

9 Id. See also Richard H. Steinberg, Judicial Lawmaking at the WTO: Discursive, Constitutional, and Political Constraints, 98 AM. J. INT'L. L. 247, 257-62 (2004) (noting that various competing doctrines influence judicial decision-making).

10 See Peter M. Gerhart, The Two Constitutional Visions of the World Trade Organization, 24 U. PA. J. INT'L ECON. L. 1, 9 (2003) (exploring the external, participatory vision of the constitutional legitimacy of the WTO, which is consistent with the economic model, but emphasizes the democratic nature of the WTO); Joseph Straus, The Impact of the New World Order on Economic Development: The Role of the Intellectual Property Rights System, 6 J. MARSHALL REV. INTELL. PROP. L. 1, 10 (2006) (referring to the power-based system within the FTAs and TRIPS-Plus agreements); Joseph Straus, Comment, Bargaining Around the TRIPS Agreement: The Case 
Equally important is the notion that the bargaining situation of developing countries has typically been understood from a relatively narrow standpoint. Conventional analysis measures power by a ballpark estimate of market size that is based on the overall size and diversity of each country's economy. ${ }^{12}$ It adopts the perspective of governments, which treat domestic market opening as a cost, and foreign market opening and associated increases in export opportunities as domestic political benefit. ${ }^{13}$ In both theory and practice, however, this framework is flawed in two ways. First, it tends to ignore the broader options before each developing country in the course of the bargaining process. Bargaining theory illuminates these options by describing two additional factors beyond the issue of market power. The first of these factors is the country's 'outside option', which entails its expected payoff in the absence of an agreement with the patentee. The identification of the outside option is significant, for instance because reaching an agreement with the patentee may become unappealing if the alternative, the unilateral issuance of a compulsory license, is sufficiently attractive. ${ }^{14}$ The second factor relates to the country's 'inside options', which are the actions that the country may take in order to

for Ongoing Public-Private Initiatives to Facilitate Worldwide Intellectual Property Transactions, 9 DUKE J. COMP. \& INT'L L. 91, 95 (1998) (describing the effect of the TRIPS Agreement on international trade and the flexibility it gives nations to exploit patents).

11 See Gregory Shaffer, Power, Governance and the WTO: A Comparative Institutional Approach, in POWER AND GLOBAL GOVERNANCE 130, 133-40 (Michael Barnett \& Raymond Duvall eds., 2004) (analyzing how the United States, EU, and constituents within them advance their interests within the WTO); Richard H. Steinberg, In the Shadow of Law or Power? Consensus-Based Bargaining and Outcomes in the GATT/WTO, 56(2) INT'L. ORG. 339, 342-43 (2002) (explaining how consensus decision-making operates in practice in the GATT/WTO legislative context and why the consensus rule has been maintained).

12 Steinberg, supra note 11, at 347

13 Id.

14 See Abhinay Muthoo, A Non-Technical Introduction to Bargaining Theory, 1 WORLD ECON. 145, 159 (2000) [hereinafter Muthoo, Non-Technical Bargaining] (exploring the fundamentals of bargaining theory, including: sources of bargaining power, bargaining strategies, variables affecting negotiating outcomes, and factors affecting negotiation speed); ROBERT D. COOTER, THE STRATEGIC CONSTITUTION 274 (2000) (referring to the outside option as a party's "threat value"). See generally Leigh L. ThOMPSON, The Mind AND HeART Of the Negotiator (2nd ed. 2001) (referring to the outside option as the "reservation value" or "disagreement value"). 
derive positive payoffs while temporarily disagreeing in the course of the bargaining process. ${ }^{15}$ Developing countries make use of an inside option, for instance, when they avoid de facto protecting intellectual property rights while formally complying with the TRIPS Agreement. 16

A second way in which the GATT/WTO system is flawed in its attempt to explain the bargaining situation of developing countries in the post-WTO era relates to two special characteristics of contemporary intellectual property-sensitive bargaining. The first feature is that innovation in intellectual property-sensitive technologies creates a paradoxical effect within the group of innovative Newly Industrialized Countries ("NICs"). The paradox lies in that innovation weakens, rather than boosts, their bargaining power vis-à-vis the prospect of bargaining retaliations. This conspicuously is the case of the prospects of issuance of compulsory licenses over pharmaceutical patents. The second insight deemphasizes the practical significance of the Least-Developed-Country ("LDC") carve-out contained in TRIPS and other WTO agreements. Specifically, as this Article shows, distributive justice policies contained in TRIPS should be geared toward a broader group of weak developing countries extending beyond the group of LDCs. This theory points out to a tentative threefold typology of developing countries based on their bargaining power. Accordingly, developing countries are modeled as HBPs, MBPs, and LBPs depending on whether they are relatively high, medium, or low-bargaining power countries, respectively.

15 Muthoo, Non-Technical Bargaining, supra note 14, at 149, 157-60.

16 See Robert M. Sherwood, Global Prospects for the Role of Intellectual Property in Technology Transfer, 42 IDEA 27, 30 (1997) (noting that the judicial systems in perhaps eighty percent of the countries of the world are simply not up to the task of supporting intellectual property rights, much less dealing effectively with other matters); Robert M. Sherwood, Some Things Cannot Be Legislated, 10 CARDOZO J. INT'L \& COMP. L. 37, 37 (2002) (“[I]ntellectual property systems involve a high degree of administrative and judicial discretion. Unless those who operate these systems hold a belief that they serve local interests, international rules, however derived or enforced, are likely to achieve little."); Agreement on Trade-Related Aspects of Intellectual Property Rights art.1, Apr. 15, 1994, Marrakesh Agreement Establishing the World Trade Organization, Annex 1C, 1869 U.N.T.S. 299 [hereinafter TRIPS Agreement] (defining the four key tenets of national enforcement provisions, which are largely modeled on American intellectual property law). 
Part 2 describes the transition between the pre- and post-WTO legal and institutional frameworks pertaining to intellectual property bargaining. It claims the new framework crystallized a twotiered bargaining situation over the conditions of access by developing countries to intellectual property-based products and technologies generated in developed ones. In this two-tiered bargaining situation, developing countries bargain simultaneously with governments of developed countries (Tier-1 bargaining) and with the industry (Tier-2 bargaining). ${ }^{17}$ Against this backdrop, postWTO international intellectual property regulation generally influenced the bargaining power of developing countries, but unequally so. This lays the conceptual foundations for the description of the bargaining situation of developing countries in terms of their outside option, inside options, and market power. The pharmaceutical industry, being a prototypical patent-sensitive industry, serves as a working example in which to apply this framework.

Part 3 employs concrete case studies to propose a conceptual shift. That shift would usher the analysis from the current dichotomous view of a developing-developed country typology, into a more complex one that divides developing countries in three categories, namely High-Bargaining Power Countries ("HBPs"), Medium-Bargaining Power Countries ("MBPs"), and Low Bargaining Power Countries ("LBPs"). While limited to assessing the country's ability to circumvent TRIPS provisions through compulsory licenses, this typology highlights: the distinctive position of NICs in comparison to the remainder of developing countries; the existence of unequal levels of innovation within parts of the developing world, particularly within certain NICs; and perhaps most importantly, the notion that distributive justice policies contained in TRIPS should be geared toward a broader group of countries.

Part 4 concludes with a set of policy ramifications. It contests the institutional favoritism of LDCs over a broader group of developing countries, such as within the 2005 Hong Kong declaration. In addition, it argues that the HBP-MBP-LBP underlying develop-

17 See Robert D. Putnam, Diplomacy and Domestic Politics: The Logic of TwoLevel Games, 42(3) INT'L ORG. 427, 434-36 (1988) (discussing the two-level approach to international decision-making); Ravi Ramamurti, The Obsolescing 'Bargaining Model'? MNC-Host Country Developing Country Relations Revisited, 32 J. INT'L Bus. STUD. 23 (2001) (discussing under which circumstances tier-1 and tier-2 bargaining manifest) 
mental inequality shifts the optimal balance between static and dynamic efficiencies. In that sense, TRIPS may prove ineffective in promoting dynamic long-term innovation policies for developing countries.

\section{THE POST-WTO IPR BARGAINING SITUATION}

\subsection{Overview}

The post-WTO intellectual property regulation framework weakened the bargaining power of developing countries, but unequally so. This argument can be broken into two subsets. First, the legalization of international intellectual property regulation under TRIPS reduced the transactions costs for beneficiaries of intellectual property protection in the developed world to promote favorable action by their governments. This is true regarding the issuance of trade sanctions, but also more broadly with respect to diplomatic pressure. As such, the TRIPS Agreement and the postWTO framework in general crystallized a two-tiered bargaining dynamic over the conditions for access by developing countries to intellectual property-based products and technologies generated in developed countries. ${ }^{18}$

In what is the first tier of negotiations, bargaining involves only national governments. ${ }^{19}$ Typically, such "Tier-1" bargaining tends to oppose net exporters and importers of intellectual propertybased products and technologies. ${ }^{20}$ Simultaneously, developing countries undergo a second tier of negotiations. "Tier-2" bargaining involves governments of developing countries and the indus-

\footnotetext{
18 See Putnam, supra note 17.

19 See Ramamurti, supra note 17.

20 See, e.g., Peggy B. Sherman \& Ellwood F. Oakley, Pandemics and Panaceas: The World Trade Organization's Efforts to Balance Pharmaceutical Patents and Access to AIDS Drugs, 41 AM. Bus. L. J. 353, 363-82 (2004) (discussing Article 27 of the TRIPS Agreement and its impact on international patent protection). But see G. Richard Shell, Trade Legalism and International Relations Theory: An Analysis of the World Trade Organization, 44 DUKE L.J. 829, 843-44 (1995) (highlighting historical antagonism between Europe and the United States over the need for a strong, binding system of dispute resolution for the GATT). See generally DANIEL GERVAIS, THE TRIPS AGREEMENT: DRAFTING HISTORY AND ANALYSIS (2nd ed. 2003) (analyzing the TRIPS Agreement by providing a summary of the negotiation, commentary, and dispute-settlement cases).
} 
try. ${ }^{21}$ Because nowadays holders of intellectual property rights, and patentees in particular, are commonly multinational enterprises ("MNEs"), the bargaining between the technology 'haves' and the 'have-nots' typically cuts transnationally as well.22 In practice, one of the most important aspects of this two-tiered bargaining dynamic is that it consolidates a two-tiered sanctions cost structure that may be levied against developing countries. To illustrate, developing countries that issue compulsory licenses run the risk of being sanctioned at both bargaining levels. In what are Tier-1 sanctions, such developing countries may be sanctioned by the governments of developed countries; and in what are Tier-2 sanctions, they may be sanctioned by the industry as well. This dual sanction cost structure is in reality the main way in which the postWTO intellectual property framework may be said to have generally reduced the bargaining power of developing countries.

Second, the disempowerment of developing countries has not been uniform. Proponents of TRIPS usually claim that the agreement positively affects Foreign Direct Investment ("FDI"), trade and innovation within developing countries. However, the way in which these variables play out in developing countries primarily depends on localized and country-specific considerations. In this respect, a development inequality principle ${ }^{23}$ suggests, first, the existence of a divide between NICs and the remaining developing countries. NICs differ in that their large and fast-growing domestic markets position them as strategic destinations for FDI and trade. To a certain extent, NICs can make use of this advantage irrespective of their general institutional framework or their intellectual property framework. ${ }^{24}$ In addition, this development inequali-

21 See Ramamurti, supra note 17; see also Putnam, supra note 17.

22 Peter Drahos \& John Braithwaite, Information Feudalism: Who OWNS THE KNOWLEDGE ECONOMY? 10-13 (2002) (explaining why states would give up sovereignty over fundamental property laws and sign the TRIPS Agreement); Eyal Benvenisti, Exit and Voice in the Age of Globalization, 98 MICH. L. REV. 167, 184-96 (1999) (describing, among other things, transnational trade and its implications for developing economies).

23 For more information on the "development inequality principle," see discussion infra Parts 2.2.1 and 2.2.2.

24 See Ha-Joon Chang, Institutional Development in Historical Perspective, in RETHINKING DEVELOPMENT ECONOMICS 499, 503-06 (Ha-Joon Chang ed., 2003) (exploring, through a historical approach, how developing countries can establish institutions that will aid in development). 
ty principle reveals that there is another divide within developing countries, namely the divide between innovative and noninnovative developing countries. Yet, and perhaps to the surprise of the TRIPS aficionados, the number of innovative developing countries remains extraordinarily small.

\subsection{Bargaining Transition in the Post-WTO Era}

\subsubsection{Development Inequality Principle}

Policy and academic analyses of TRIPS often give little attention to the various ways in which the agreement affects different developing countries. ${ }^{25}$ Traditional approaches typically proceed from the well-known North/South dichotomy, or some variation thereof.26 This framework highlights the asymmetries between Northern countries, which are deemed to generate innovative products and technologies, and Southern countries, which are generally deemed to consume them. ${ }^{27}$ A closer look at developing

25 See, e.g., WORLD InTEllectuAl PROPERTY ORG., http://www.wipo.int /portal/index.html.en (last visited Oct. 6, 2010); U.N. DEP'T OF ECON. AND SOC. AFF., http://www.un.org/en/development/desa /index.shtml/ (last visited Oct. 6, 2010). For theoretical and empirical studies, see Helge E. Grundmann, Foreign Patent Monopolies in Developing Countries: An Empirical Analysis, 12 J. DEVT'L. STUD. 186 (1976) (arguing that patent protection in developing countries is not beneficial because of the strong focus on advanced technologies which are inaccessible to developing countries); Douglas F. Greer, The Case against Patent Systems in LessDeveloped Countries, 8 J. INT'L L. \& ECON. 223 (1973) (arguing that strong patent protection impedes technological and economic advancement in less-developed countries); Constantine Vaitsos, Patents Revisited: Their Function in Developing Countries, 9 J. DEVT'L STUD. 71, 89-90 (1972) (comparing countries with "prior examinations" of patents to countries without "prior examinations" of patents). But see Daniel C. K. Chow, The Role of Intellectual Property in Promoting International Trade and Foreign Direct Investment, in 4 INTELLECTUAL PROPERTY AND INFORMATION WEALTH 187, 197-99 (Peter K. Yu ed., 2007) (noting that China has power to draw in investment from foreign sources despite its weak intellectual property rights); F. M. SCHERER, INDUSTRIAL MARKET STRUCTURE AND ECONOMIC PERFORMANCE (1971) (analyzing issues of industrial growth through a study of structural constraints of industrial organization).

26 See, e.g., Paul Krugman, A Model of Technology Transfer, and the World Distribution of Income, 87 J. POL. ECON. 253, 254-55 (1979) (analyzing the TRIPS Agreement via the innovating North and non-innovating South).

27 See Carlos M. Correa, Intellectual Property Rights, the WTO AND Developing Countries: The TRIPS AgReEment And POlicy Options 5-6 (2000) 
[Vol. 32:1

countries, however, reveals that the effects of the TRIPS Agreement are much more varied and can hardly be understood along this bipolar, North/South line alone. Developing countries differ not only in their propensity to attract FDI, trade, and technology, but also in their abilities to innovate and to make use of intellectual property protection as a tool that fosters domestic innovation. This set of circumstances, which unequally affects the bargaining power of developing countries, is herein referred to as the development inequality principle.

There has been a sharp divide in the economic development strategies employed within the developing world in the period preceding the adoption of TRIPS worldwide. A few countries, particularly Japan and the East Asian "tigers" of Hong Kong, South Korea, Singapore and Taiwan, have managed to successfully adopt an export promoting industrialization ("EP") strategy, rather than an import substituting ("IS") strategy. ${ }^{28}$ Successful implementation of the EP strategy helped these countries receive higher levels of sustained inflows of FDI and derive more benefits from this increased FDI inflow. ${ }^{29}$ By the turn of the last century, the East Asian Tigers were no longer deemed developing countries, but rather developed countries. ${ }^{30}$ In the course of their transition toward becoming exporters of technology-based products, the East Asian Tigers rapidly foresaw the benefits of adhering to the TRIPS package.

Most of the remaining latecomers to post-World War II industrialization embraced IS strategies. ${ }^{31}$ Academics debate about whether IS was merely a poor policy choice or a natural conse-

(describing the asymmetrical distribution of technological innovation and consumption between Northern and Southern countries).

28 Howard Handelman, The Challenge of Third World Development 297-300 (5th ed. 2009).

29 Jagdish Bhagwati, The Wind of the Hundred Days: How Washington MismanAGED GLOBALIZATION 37-46 (2000).

30 See Int'l Monetary Fund, Country Composition of WEO Groups, WORLD ECONOMIC OUTLOOK, DATABASE - WEO GROUPS AND AGGREGATES INFORMATION 2-3 (Oct. 2008) (categorizing Hong Kong, South Korea, Singapore and Taiwan as "Newly Industrialized Asian Economies" instead of "Emerging and Developing Economies").

31 See Cláudio D. Shikida, Brazil: From Import Substitution to the 21st Century. What is Left to Do? 2 (Ibmec MG, Working Paper No. WP30, 2005) (providing a detailed description of import substitution strategies). 
quence of local economic, political and social conditions that prevented countries from pursuing EP strategies. ${ }^{32}$ Nonetheless, the fact remains that IS proved a less successful path than EP. ${ }^{33}$ Grounded on dependency theories of development, IS theorists concluded that freer trade would immiserate countries of the "periphery." 34 Local policies responded accordingly, and these countries grew increasingly suspicious of foreign investment and trade liberalization. In the past two decades, however, fears of economic integration within the developing world have given way to far greater optimism. ${ }^{35}$ In what has been referred to as an ironic reversal, anti-globalization sentiments now seem to be more prevalent in wealthier countries than in poorer countries. ${ }^{36}$ In fact, as of the 1980s and 1990s, most developing countries had opened their markets to foreign investment and trade, leaving behind decades of inward-oriented industrialization policies. Predictably, the results of adhering to free market policies were generally uneven. ${ }^{37}$

Although most developing countries had reservations about strengthening intellectual property rights, signing the TRIPS Agreement was a condition for participating in the WTO. Being a WTO-member was, and still is, generally viewed as an essential component of their participation in the international wave of trade

32 See, e.g., Chang, supra note 24, at 499-522 (describing external political and economic limitations which can hinder institutional development).

33 BHAGWATI, supra note 29, at 143.

34 See Raul Prebisch, International Trade and Payments in an Era of Coexistence: Commercial Policy in the Underdeveloped Countries, 49 AM. ECON. REV. 251, 251-52 (1959) (providing examples of reasoning used by "periphery" countries which foster an aversion to increasing free trade); FERNANDO HENRIQUE CARDOSO \& ENZO FALETTO, DEPENDENCY AND DEVELOPMENT IN LATIN AMERICA 149-71 (1979) (describing the tension between nationalist and populist political agendas in Latin Ameri$\mathrm{ca}$ and the influences of this tension on international trade policies).

35 BHAGWATI, supra note 29 , at 144.

36 JaGDish BHAGWATI, IN DEFENSE OF GLOBALIZATION 8-10 (2004).

37 This is true even if one assumes, as many do, that this "new" form of capitalism benefits everyone; a proposition that we neither accept nor dispute. See id. at 10-11 (suggesting that unrelated changes in circumstance may be an alternate cause of positive business growth polls). But see DiAnE COYLE, PARADOXES OF PROSPERITY: Why THE NEW CAPITALISM BENEFITS All 148 (2001) (explaining why twenty-first century "New Capitalism" has the potential to be more beneficial and more equitable than its predecessor). 
and prosperity of a globalized world. ${ }^{38}$ The TRIPS Agreement consists of a broad, but controversial, reform agenda for an intellectual property regime that applies almost flatly to all WTO-members. ${ }^{39}$ The mandatory adoption of TRIPS standards creates two imperative costs for developing countries, namely reduced access to new technologies, knowledge, and higher royalty payments. ${ }^{40}$ Against that backdrop, defenders of TRIPS have tried to cast intellectual property protection as a central pillar of modern economic policy and a catalyst for development, an argument that is twofold. ${ }^{41}$ First, intellectual property protection is said to explicitly encourage domestic innovation in developing countries, similar to the development of protections that took place in the early history of the United States. ${ }^{42}$ Second, intellectual property protection is thought to induce more inward technology transfer, particularly by means

38 See John A. Harrelson, TRIPS, Pharmaceutical Patents, and the HIV/AIDS Crisis: Finding the Proper Balance between Intellectual Property Rights and Compassion, 7 WID. L. SYMP. J. 175, 187-88 (2001).

39 See, e.g., Michael Blakeney, The International Protection Of INDUSTRIAl PROPERTY: From THE PARIS CONVENTION TO THE TRIPS AgREEMENT 1322 (2003) (detailing the large number of generally applicable provisions and principles within the TRIPS Agreement).

40 See Christopher S. Gibson, Globalization and the Technology Standards Game: Balancing Concerns of Protectionism and Intellectual Property in International Standards, 22 BERKELEY TECH. L.J. 1403, 1404-06 (2007).

41 See SHAHID AlikHAN, SOCIO-ECONOMIC BENEFITS OF INTELlECTUAL PROPERTY PROTECTION IN DEVELOPING COUNTRIES 1-9 (2000) (arguing that intellectual property protection is an integral part of the technological and economic development at a national and international level); KAMIL IDRIS, INTELLECTUAL PROPERTY: A POWER TOOL FOR ECONOMIC GROWTH 1 (2d ed. 2003) (introducing the argument that intellectual property is a powerful force to benefit individuals and nations); Ali Imam, How Patent Protection Helps Developing Countries, 33 AIPLA Q.J. 377, 379-80 (2005) (detailing the social and economic benefits of stronger patent protection in developing countries).

42 See Robert M. Sherwood, Human Creativity for Economic Development: Patents Propel Technology, 33 AKRON L. REV. 351 (2000) (discussing the way in which communities chose to protect technology so that the entire community could profit throughout different stages of intellectual property development). But see F. M. Scherer, The Political Economy of Patent Policy Reform in the United States, 7 J. TELECOMM. \& High TECH. L. 167, 205 (2009) (arguing that the historical parallel to the United States "also overlooks the fact that during the first 47 years of its existence, the United States provided strong patent protection to domestic residents, but denied patents to foreigners, whereas LDCs were being asked under TRIPS to increase the scope of their patent protection to both domestics and foreigners"). 
of enhanced FDI and trade carried out by multinational enterprises ("MNEs"). ${ }^{43}$ According to this theory, the availability of intellectual property protection would be akin to a "passive" industrial policy - it would stimulate innovation without requiring large investments of public funds often lacking in the developing world.44

This uniform analysis when broadly applied to all developing countries, however, overlooks the fact that the pro-TRIPS and antiTRIPS considerations play out dissimilarly in different parts of the developing world. First, the existence of an intellectual property protection-innovation link is in many cases highly questionable. Historically, a strong intellectual property system appears to have been neither necessary nor sufficient for progress at national and company level. 45 In fact, it is a well-recognized fact that broad in-

43 See Keith E. Maskus, Intellectual Property Rights IN the Global ECONOMY 11 (2000) (arguing that stronger patent protection benefits international trade and FDI); Keith E. Maskus \& Mohan Penubarti, How Trade-Related are Intellectual Property Rights?, 39 J. INT'L ECON. 227, 229-30, 237-43 (1995) (determining that intellectual property rights directly influence the flow of trade). See generally Daniel J. Gervais, Information Technology and International Trade: Intellectual Property, Trade E Development: The State Of Play, 74 FordHAM L. REV. 505, 517-21 (2005) (analyzing the effects of intellectual property protection on bilateral trade and "inward" FDI); Edmund W. Kitch, The Patent Policy of Developing Countries, 13 UCLA PAC. BASIN L.J. 166, 174-76 (1994) (arguing that developing countries opt into the international property system because it is in their self-interest to do so); Keith E. Maskus, The Role of Intellectual Property Rights in Encouraging Foreign Direct Investment and Technology Transfer, 9 DUKE J. COMP. \& INT'L L. 109 (1998) [hereinafter Maskus, The Role of Intellectual Property Rights] (describing the various factors involved in improving a nation's FDI); Carlos A. Primo Braga and Carsten Fink, The Relationship Between Intellectual Property Rights and Foreign Direct Investment, 9 DUKE J. COMP. \& INT'L L. 163 (1998) (describing the influence of strong IP protection on the levels of FDI).

44 See, e.g., Kenneth W. Dam, The Economic Underpinnings of Patent Law, 23 J. LEGAL STUD. 247, 271 (1994) (discussing the economic repercussions of intellectual property protection and the economic policies which influence patent law); Robert D. Cooter and Hans-Bernd Schaefer, Solomon's Knot: How Law Can End the Poverty of Nations (2009) (unpublished manuscript), available at http://works.bepress .com/robert_cooter/151 (discussing the role of innovation in the economic growth of developing nations).

45 See, e.g., Ove Granstrand, Innovation and Intellectual Property Rights, in THE OXFORD HANDBOOK OF INNOVATION 284 (Jan Fagerberg et al. eds., 2006); ERICH KAUfER, THE ECONOMICS OF THE PATENT SYSTEM 25 (1989); Josh Lerner, The Economics of Technology and Innovation: 150 Years of Patent Protection, 92 AM. ECON. REV. 221, 221-25 (2002) (describing different models of intellectual property regimes); Fritz Machlup \& Edith Penrose, The Patent Controversy in the Nineteenth Century, 10 
tellectual property protection in cumulative innovation processes can stifle subsequent innovation. ${ }^{46}$ Moreover, more modern research on the contributions of strong intellectual property systems internationally, and the TRIPS Agreement in particular, have also failed to demonstrate how a more stringent intellectual property regime can foster innovation in the developing world at large. ${ }^{47}$ Innovation springs from the creative application of knowledge, but its underlying conditions are necessarily complex; many are not easily altered by policy; and some are the result of cultural evolutionary processes which extend beyond the reach of short-term policymaking. ${ }^{48}$

J. ECON. HIST., May 1950 at 1, 24 (arguing that, historically, strong patent protection has a stifling effect on innovation because it deprives society of the flow of information from more widespread use of ideas); Petra Moser, How Do Patent Laws Influence Innovation? Evidence from Nineteenth-Century World's Fairs, 95 AM. ECON. REV. 1214 (2005) (analyzing data on innovations that occur with and without patent protections in order to consider the effects of patent law on innovation).

46 See Nancy Gallini \& Suzanne Scotchmer, Intellectual Property: When Is It the Best Incentive System?, 2 INNOVATION POL'Y \& ECON. 51, 68 (2002) (describing the obstacles to innovation which can be created by the implementation of broad intellectual property rights); Roberto Mazzoleni \& Richard R. Nelson, The Benefits and Costs of Strong Patent Protection: A Contribution to the Current Debate, 27 RES. POL'Y 273, 281 (1998) (stating that the large economic costs imposed by strong patent protection do not outweigh the benefits of such a system); Robert P. Merges \& Richard R. Nelson, On the Complex Economics of Patent Scope, 90 CoLuM. L. REV. 839, 894-97 (1990) (analyzing the effects that patents had on cumulative technology products such as automobiles and airplanes throughout American history); Suzanne Scotchmer, Standing on the Shoulders of Giants: Cumulative Research and the Patent Law, 5 J. ECON. PERSP., Winter 1991, at 29, 37 (1991) (emphasizing the importance of protecting cooperation and collective works when determining the scope of patent protection laws). But see Edmund W. Kitch, The Nature and Function of the Patent System, 20 J.L. \& ECON. 265, 267 (1977) (sustaining that broad patents stimulate further developments and enhance the public welfare); see also Jerry R. Green \& Suzanne Scotchmer, On The Division Of Profit In Sequential Innovation, 26 RAND J. ECON. 20, 31 (1995) (explaining circumstances in which even ex ante agreements may not prevent intellectual property protection from hindering innovation); Oren Bar-Gill and Gideon Parchomovsky, The Value of Giving away Secrets, 89 VA. L. REV. 1857, 1884 (2003) (showing that in some circumstances, the initial inventor-especially in the case of cumulative innovations-will prefer a narrow patent).

47 Granstrand, supra note 45.

48 See generally DAVID S. LANDES, THE WeALTH AND POVERTY OF NATIONS: WHY SOME ARE SO RICH AND SOME SO POOR (1998) (describing the numerous climatolog- 
In addition, there is now evidence that the weight of domestic research and development on productivity is largely dependent on the market size of an economy. ${ }^{49}$ Since Romer's endogenous growth models were proposed,50 development economics has increasingly focused its attention on endogenous technological change to explain the growth patterns of world economies. In endogenous growth models, as Ulku notes:

[T]echnological innovation is created in the research and development (R\&D) sectors using human capital and the existing knowledge stock. It is then used in the production of final goods and leads to permanent increases in the growth rate of output. At the heart of these models is their postulation that endogenously determined innovation enables sustainable economic growth .... .51

Recent studies suggest, however, that a key determinant of innovation is the potential market size of users. ${ }^{52}$ That is, the availability of a large domestic market significantly determines the ability of a country to increase its innovation by investing in research and development. ${ }^{53}$ It follows that larger developing countries can potentially derive higher benefits from intellectual property protection. Second, "whether IPR protection is an important determinant in the locational competition for FDI in R\&D remains unsettled.

ical, historical and cultural circumstances which had a significant and complex influence on the economic development of various nations throughout the world).

49 See Daron Acemoglu \& Joshua Linn, Market Size and Innovation: Theory and Evidence from the Pharmaceutical Industry, 119 Q. J. ECON. 1049, 1049-50 (2003) (exploring the effect of potential market size on the entry of drugs into the market); Hulya Ulku, $R$ E D, Innovation, and Economic Growth: An Empirical Analysis 4 (Int'1 Monetary Fund, Working Paper No. 04/185, 2004) (determining whether innovation is created in the R\&D models and whether it creates sustainable economic growth).

50 See Paul M. Romer, The Origins of Endogenous Growth, 8 J. ECON. PERSP. 3, 3 (1994) (recounting the two primary paradigms for understanding the development of endogenous growth theory); Paul M. Romer, Endogenous Technical Change, 98 J. Pol. ECON. S71, S71 (1990) (determining that the stock of human capital determines rate of growth); Paul M. Romer, Increasing Returns and Long-Run Growth, 94 J. POL. ECON. 1002, 1002 (1986) (presenting a model of long-run growth in which knowledge is an input in production that has increasingly marginal productivity).

51 Ulku, supra note 49 , at 4 .

52 Acemoglu \& Linn, supra note 49 , at 1050.

53 Ulku, supra note 49 , at 4. 
Theoretical reasoning and empirical investigations point to an ambiguous relationship between IPR protection and the distribution of FDI across countries. ${ }^{54}$

Host-country characteristics are significant because intellectual property protection has weaker effects in countries with strong market-related pull factors for FDI, such as large markets of abundant natural resources. ${ }^{55}$ There is also some evidence that FDI responds to intellectual property protection only in host-countries that have reached a minimum threshold of development and have a capacity to imitate inventions. ${ }^{56}$ Naturally, the impact of intellectual property protection is stronger in human-capital and technology intensive industries such as pharmaceuticals, cosmetics and health care products, chemicals, machinery and equipment, and electrical equipment. ${ }^{57}$ Nevertheless, even in these industries, investment decisions remain contingent on many other factors. ${ }^{8}$ It must also be noted that intellectual property law is not the only mechanism for protection of knowledge and information, and at

54 Peter Nunnenkamp \& Julius Spatz, Intellectual Property Rights and Foreign Direct Investment: The Role of Industry and Host-Country Characteristics 2 (Kiel Instit. for World Econ., Working Paper No. 1167, June 2003). See generally Comm'n on Intellectual Prop. Rights, Integrating Intellectual Property Rights and Development Policy 22-23 (2002), available at http://www.iprcommission.org/papers/pdfs / final_report/CIPRfullfinal.pdf [hereinafter Comm'n on IPR] (examining the dynamics of the relationship between intellectual property rights protection and facilitating development).

55 Nunnenkamp \& Spatz, supra note 54, at 12-13.

56 Id.

57 See Beata S. Javorcik, The Composition of Foreign Direct Investment and Protection of Intellectual Property Rights: Evidence from Transition Economies, in INTELLECTUAL PROPERTY AND DEVELOPMENT: LESSONS FROM RECENT ECONOMIC RESEARCH 133, 134 (Carsten Fink \& Keith E. Maskus eds., 2005) (noting that in intellectual property rights play an important role in high-technology sectors); Carlos A. Primo Braga \& Carsten Fink, International Transactions in Intellectual Property and Developing Countries, 19 INT'L J. TECH. MGMT. 35, 38-42 (2000) (explaining that intellectual property rights protection will have a strong affect on trade in knowledge-intensive goods). But see Edwin Mansfield, Intellectual Property Protection, Direct Investment, and Technology Transfer 27 (Int'l Fin. Corp. Discussion Paper No. 19, 1994) (interviewing executives who believe that intellectual property protection is not a major criteria for investment).

58 See Comm'n on IPR, supra note 54, at 23 (noting that intellectual property rights may not be as important in investment decisions as other factors). 
times not even the most important. ${ }^{59}$ This statement remains true even for patent-sensitive industries, and remarkably so. ${ }^{60}$ In the chemicals industry, for instance, there is evidence that MNEs tend to prefer stand-alone operations abroad and to employ a relatively small number of workers as a means of knowledge protection. ${ }^{6}$ Another important patent-sensitive industry that tells a similar story is the bio-agriculture and plant genetics. As such industry, the scientific industrial nature of agricultural biotechnology noticeably shifts agriculture from land-based farming to the interdisciplinary patent-based industries of therapeutics, pharmaceuticals and chemicals, and thus is of central importance to the Post-WTO bargaining model and the developing countries inequality principle herein. 62

With agricultural biotechnology, therefore, the inequality principle is thus also ever-present. The International Union for the Protection of New Varieties of Plants ("UPOV") establishes the plant variety protection ("PVP") framework known as the Plant Breed-

59 See, e.g., Lawrence Lessig, Free Culture: How Big Media Uses Technology AND THE LAW TO LOCK DOWN CUlture AND CONTROL CREATIVITY 261 (2004) (arguing that a sensible patent policy is compatible with some free flow of information); Yochai Benkler, Coase's Penguin, or, Linux and The Nature of the Firm, 112 YALE L.J. 369, 444 (2002) (describing the growth of peer-produced knowledge); Yochai Benkler, Through the Looking Glass: Alice and the Constitutional Foundations of the Public Domain, 66 LAW \& CONTEMP. PROBS. 173, 222 (2003) (describing the importance of congressional constraints on exclusive private rights in order to reduce costs to democracy and autonomy).

60 See generally Henrique M. Barros, The Impact of the Distribution of RED Expenses on Firms' Motivations to Patent 1 (INSPER Working Papers No. 148, 2008) available at http://ideas.repec.org/p/ibm/ibmecp/wpe_138.html (demonstrating that development-oriented firms do not always pursue patents).

61 Nunnenkamp \& Spatz, supra note 54, at 34.

62 See Sheldon Krimsky \& Roger P. Wrubel, Agricultural Biotechnology AND THE ENVIRONMENT: SCIENCE, POLICY, AND SOCIAL ISSUES 227 (1996) (noting the blurring of the traditional distinction between agriculture and chemical manufacture); ORG. FOR ECON. CO-OPERATION \& DEV., BIOTECHNOLOGY AND THE CHANGING ROLE OF GOVERNMENT 12 (1988) (arguing that biotechnology has an impact on agricultural practices). To be sure, the TRIPS Agreement brings animals, plants, and plant varieties within the scope of patentable protection, subject to the individual members' regulatory choice. See TRIPS Agreement, supra note 16, art. 27.3(b) (dealing with patentable subject matter). In relation to plant varieties, in particular, it offers members the option to choose modes of protection between "patents or ... effective sui generis system or ... any combination thereof." Id. 
ers' Rights ("PBRs") regime for UPOV member states. ${ }^{63}$ PBRs provide a site for understanding intellectual property's role in the intersection between the international agriculture regime, traditional agricultural practices ("TAPs") deployed by indigenous and local farming communities, and food security. In this regard, since the 1980s, the FAO has been involved in the juridical evolvement of the concept of "farmers' rights" as a counterbalance to PBRs. ${ }^{64}$ Farmers' rights, to be sure, are integral to a regime of open access to genetic resources in ex situ public seed banks. The International Treaty on Plant Genetic Resources for Food and Agriculture ("ITPGRFA") regulates them.65 With time, regrettably, the usage of these resources, noticeably in regard to access to the genetic resources from the putative common pool, created a crisis of confidence between the developed and the underdeveloped world, but unevenly so. ${ }^{66}$ In addition, farmers' rights are subject to preexisting national laws and bilateral treaty obligations of differing financial effect. For the most part, these include PBRs and patents

63 See Int'L Union for the Protection of NeW Varieties of Plants Home PAGE, http://www.upov.int/index.html (last visited Nov. 4, 2010) (stating the purpose is to protect new varieties of plants by an intellectual property right).

64 See, e.g., Laurence R. Helfer, Intellectual Property Rights in Plant Varieties: An Overview with Options for National Governments (Food \& Agriculture Organization of the U.N., Legal Papers Online No. 31, 2002), available at http://www.fao.org /Legal/Prs-OL/lpo31.pdf.

65 See International Treaty on Plant Genetic Resources for Food and Agriculture [hereinafter International Plant Treaty], art 1.1 (opened for signature Nov. 3, 2001), available at http://www.fao.org/Legal/treaties/033t-e.htm (noting that the purpose of the Treaty is to conserve and sustain use of plant genetic resources for food). A chief example for the latter is the well-known International Agricultural Research Centers ("IARCs") designed to preserve the world's scarce genetic resources for food and agriculture. For other seed banks, see Report of the Conference of Food and Agriculture Organization, Nov. 5-23, 1989, International Undertaking on Plant Genetic Resources for Food and Agriculture, art. 1, 22nd Sess., U.N. Doc. C/83/REP (1983) (Nov. 23, 1989); Report of the Conference of Food and Agriculture Organization, FAO Res. 5/89, U.N. Doc. C/89/24 (1989) cited in International Environmental Law Research Center, IELRC Briefing Paper 2003-2, available at http://www.ielrc.org/content/f0302.htm.

66 Chidi Oguamanam, Agro-Biodiversity and Food Security: Biotechnology and Traditional Agriculture Practices at the Periphery of International Intellectual Property Regime Complex, 2007 MicH. ST. L. REV 215, 246 (2007). 
both under the UPOV and the TRIPS standards. ${ }^{67}$ The ability of farmers' rights to serve as an effective balancing regime to PBRs in particular and intellectual property rights in general hence remains further unsatisfactory for the underdeveloped world. 68

Consequently, a major study conducted in NIC countries primarily, found little correlation between the range of plant material available to farmers or increased innovation and PVP protection. ${ }^{69}$ More broadly, in the United States there was no evidence that total R\&D activity had increased as a result of the introduction of PVP.70 The great majority of private research is conducted in NICs in Asia and Latin America. Of worldwide private research expenditure over bio-agriculture and plant genetics totaling $\$ 11.5$ billion, only $\$ 0.7$ billion is attributable to developing countries at large. ${ }^{71}$ Moreover, research expenditures by these countries grew at $5-7 \%$ annually between 1976 and 1996, while they stagnated in SubSaharan African. ${ }^{72}$ Although the joint public (FAO-UNDP) and

67 See International Plant Treaty, supra note 65, art. 9.3 (noting that farmers still have rights to save and sell farm-saved seed and propagating material, but these rights subject to the appropriate national laws).

68 See Chidi Oguamanam, Intellectual Property Rights in Plant Genetic Resources: Farmers' Rights and Food Security of Indigenous and Local Communities, 11 DRAKE J. AGRIC. L. 273, 275-76 (2006) (exploring how farmers protect their knowledge of dealings with plant genetic resources for agriculture and food).

69 See Jeroen van Wijk, The Impact of Plant Breeders' Rights in Developing Countries: Results of a study in five Latin American countries, in INTELLECTUAL PROPERTY Rights AND AGRICUlture IN DEVEloping CounTRIES 8, 12-16 (Jeroen van Wijk \& Walter Jaffé eds., 1996) (discussing the various ways in which implementation of plant breeders' rights have affected access of plant material for farmers and companies).

70 See generally Anwar Naseem et al., Does Plant Variety Intellectual Property Protection Improve Farm Productivity? Evidence from Cotton Varieties, $8 \mathrm{~J}$. Agrobiotechnology Mgmt. \& Econ., No. 2, Art. 6, available at http://www.agbioforum.org/v8n23/v8n23a06-oehmke.htm (describing how researchers observed some impact on soy beans and wheat).

71 Philip G. Pardey \& Nienke M. Beintema, Slow Magic: Agricultural RED a Century After Mendel 10 (Int'1 Food Pol'y Res. Inst. 2001), available at http://www.card.iastate.edu/research/stp/papers/pardey-Slow_magic_Text _Oct_01_Final.pdf.

$72 I \bar{d}$. at 4 . As for the public sector, investment in $\mathrm{R} \& \mathrm{D}$ is more present. As compared to medical research, there is a great deal more agricultural R\&D undertaken by, and of relevance to, developing countries. In 1995, total expenditure by the public sector on agricultural research in developing countries, although un- 
private agricultural research at large, commonly referred as the Consultative Group on International Agricultural Research ("CGIAR") $)^{73}$ spends approximately $\$ 572$ million per year, ${ }^{74}$ funding by the donor community, has deduced substantively since 1990.75 Moreover, while funding from the aid donor community has stagnated, little private sector R\&D in bioagriculture is directed to poor farming in developing countries.

Similarly, in the software industry, there is no flat trend suggesting an increase in overseas $R \& D$ spending in any correlation with IPRs policies in the underdeveloped world. With respect to the United States, the most recent data from the National Science Board actually shows a "re-concentration" of investments in high technologies: "strong growth in U.S. companies' domestic R\&D financing (up to $10 \%$ ), coupled with a $7 \%$ decline in industry's overseas R\&D spending, reduced the overseas share to $8.9 \%$ of U.S. companies' funding total." 76 Out of this given small amount, developing countries capture only a marginal 6\%.77 With emphasis on software, the OECD Information Technology Outlook describes the situation as such that with very few exceptions, work outsourced does not involve "the development of mission-critical applications, nor do projects involve very sophisticated technology". ${ }^{78}$ Instead, the OECD Report adds, "[f]rom a life-cycle perspective, systems requirements, high-level design, and installa-

evenly distributed, amounted to $\$ 11.5$ billion dollars compared to the $\$ 10.2$ billion spent in developed countries. Id.

73 Established in 1971, CGIAR is a strategic partnership, whose 64 members support 15 international Centers worldwide. Who We Are, Consultative Group ON INT'L AGRICULTURAL RESEARCH, http://www.cgiar.org/who/index.html (last visited Oct. 24, 2010)

74 Originally CGIAR led the Green Revolution, and they presently act as the guardian of the world's largest collection of genetic resources. See id. (stating that eleven of CGIAR Centers maintain international gene banks that preserve a wide range of plant genetic resources).

75 See Pardey \& Beintema, supra note 71, at 9 (noting that international donor and aid agencies do not contribute the resources to agriculture they once did).

76 See NAT'L SCI. BD., SCIENCE AND ENGINEERING INDiCATORS 59-60 (2000), http:/ / www.nsf.gov/sbe/srs/seind00/start.htm (discussing R\&D funding levels in the United States and abroad).

77 Id.

78 ORg. For ECON. CO-OPERATION \& DeV., OECD INFORMATION TECHNOLOGY OUTLOOK 2000: ICTS, E-COMMERCE AND THE INFORMATION ECONOMY 137-38 (2000), available at www.oecd.org/dataoecd/30/56/1939833.pdf. 
tion and testing are typically not outsourced."79 To summarize, the various means by which intellectual property rights influence FDI are subtle, and intellectual property protection alone does not clearly generate sufficient incentives for MNEs to invest in a developing country. 80

This set of considerations explains why the effects of the TRIPS Agreement are too often highly inconsistent. Focusing on the effects of TRIPS on FDI and trade on one hand, and on innovation on the other, the development inequality principle sets out two dividing lines within the developing world. The first line is drawn between larger economies, particularly NICs, and the remaining developing countries. The category of NIC is a socioeconomic classification applied to several countries by geographers, economists, and political scientists. Manufacturing must account for a significant fraction of the NIC's gross domestic product, but aside from that, there is no undisputed or official set of criteria that allow a country to be labeled an "NIC." 81 According to Bradford, the emergence of NICs is a "generalized historical movement in which industrialized countries vacate intermediate sectors in industrial production in which advanced developing countries are currently more competitive and advanced developing countries, in turn, vacate more basic industrial sectors in which the next tier of developing countries have a relative advantage." 82 NICs are therefore

79 Id.

80 See Maskus, The Role of Intellectual Property Rights, supra note 43, at 128 (explaining that the MNEs are primarily concerned with the likelihood that FDI will raise expected profits).

81 See ANIS ChOWDHury \& IyANATUl IsLAM, THE NEWLy INDUSTRIALIZING ECONOMIES OF EAST ASIA 4 (1993) (stating that the criteria necessary for being classified as a NIC is arbitrary but lists four suggestive criterion, including a requirement that manufacturing account for at least twenty percent of the NIC's gross domestic product); see also Nigel GrimWADE, INTERNATIONAL TRADE: NeW PATterns of Trade, Production AND InVESTMENT 312 (1989) (noting there is no definitive list of NICs, but that many countries that have recently met this classification are small developing countries that are major exporters of manufactures).

82 Colin I. Bradford Jr., The Rise of the NICs as Exporters on a Global Scale, in THE NEW INDUSTRIALIZING COUNTRIES: TRADE AND ADJUSTMENT 7 (Louis Turner \& Neil McMullen eds., 1982). Accordingly, NICs tend to be more advanced than other developing countries, and less so than developed countries. There is no official or undisputed set of criteria to define an NIC, so each author sets a list of countries according to her own criteria and methods. See generally MAURO F. GUILLÉN, MultinAtionals, IDEOlOGY, AND ORGANIZED LABOR, THE LiMITS OF CONVERGENCE 
those countries that fulfill the intermediary stages in the international division of labor; and since this division is ever changing, the categorization of a country as a NIC changes as well.83 A popular method of categorization would treat as NICs only Brazil, Mexico, South Africa, China, India, Malaysia, Philippines, Thailand, and Turkey,, 8 and would refer instead to the archetypical East Asian tigers of Hong Kong, South Korea, Singapore, and Taiwan as "developed." 85

Essentially, NICs differ from the remaining developing countries because they possess large and relatively diversified domestic economies. This fact awards them the status of being strategic and fast-growing markets in and with which MNEs typically cannot refrain from investing or trading. 86 Consequently, NICs capture a disproportionately large portion of the FDI that flows to developing countries. ${ }^{87}$ In turn, the remaining developing countries receive proportionally much smaller shares of FDI. Such is the case not only for LDCs, but also for a much broader group of developing countries. Accordingly, bargaining power within NICs is generally greater than among the remaining developing countries.

This market size approximation, however, fails to recognize a second divide that exists within developing countries - that is, the divide between innovative and non-innovative developing countries. While all developing countries are innovative on some level, only a small fraction of them is innovative in the area of intellectual property-based technologies. China and India are effectively the

(2003); N. Gregory MANKIW, PRinciples of Economics, (4th ed. 2006); David WAUGH, GEOGRAPHY: AN INTEGRATED APPROACH. (3d ed. 2002).

83 GUILLÉN, supra note 82.

84 Id. See generally MANKIW, supra note 82; WAUGH, supra note 82.

85 See PAWEL BOZYK, GLOBALIZATION AND THE TRANSFORMATION OF ForEIGN ECONOMIC POLICY 164 (2006) (stating that these countries have accelerated their growth rate and made substantial changes to their economic structure).

86 See Technology in Emerging Economies, THE ECONOMIST, Feb. 9, 2008, at 75 (noting the fact that China already has the same number of mobile phone users as the whole of Europe, namely five hundred million).

87 See, e.g., Ilene Grabel, International Private Capital Flows and Developing Countries, in RethinKING DeVElopment Economics 325, 327-28 (Ha-Joon Chang ed., 2003) (explaining that financial liberalization enables NICs to capture a large portion of the FDI that flows to developing countries because these countries contain attractive short-term speculative investments and opportunities for privatization, mergers, and acquisitions). 
only developing countries that, aside from being scientifically proficient, are also able to produce technology-based products in patent-sensitive industries in large scale. ${ }^{88}$ Yet, and regrettably for TRIPS enthusiasts, these countries do not display the highest standards of TRIPS compliance within the developing world.

One could still abide by dependency theories upholding that developing countries at large - that is, Southern countries - are almost exclusively consumers of technology. Consistent with that claim, vertical industrial policies were widely applied in China and India in their steady, and yet uncertain, process of "catch up." 89 Again, academics sharply disagree on the value of such vertical policies, and positions range from claims that these policies were crucial to claims that they created more harm than good. ${ }^{90}$ Either way, the causes of the "miracle" in India and China are of no concern here; what matters is the conclusion that TRIPS plays out dissimilarly in the developing world, including with respect to its interaction with innovative activities.

At any rate, the remaining developing countries, NICs bear an advantage not only in terms of their ability to attract FDI and trade, but also in their ability to promote endogenous innovation. However, this reality does not mean that all NICs make use of their theoretical or potential ability to innovate in the same fashion. Although helpful, the availability of large domestic markets is far from a sufficient condition for a developing country to become innovative. In fact, there is a sharp divide between the "innovative"

88 See Press Release, Rand Corporation, Rand Study Says Advanced Countries Will Benefit Most from Progress in Technology, with Lesser Benefits to Other Nations (June 1, 2006), available at http://www.rand.org/news/press.06 /06.01.html (noting that China and India are the two countries with the best probability of catching up to other scientifically advanced countries).

89 See World Bank, The East Asian Miracle, Economic Growth and Public POLICY 301-04 (1993) (explaining that East Asia's productivity "catch up" was driven by a view that a world market for goods and services presented an opportunity for economic growth and productivity could be increased by importing technology through DFI or other methods like licensing or knowledge acquisition).

90 See generally Alice Amsden, Asia's NeXt Giant: South Korea And Late INDUSTRIALIZATION (1989) (defending the exceptionalism of industrial policy in East Asia); Robert WAdE, GOVERning THE MARKet: ECONOMIC THEORY AND THE ROLE OF THE GOVERNMENT IN EAST ASIAN INDUSTRIALIZATION (1990) (defending the exceptionalism of industrial policy in East Asia). But see Bhagwati, supra note 29; Cooter \& Schaefer, supra note 44 (critiquing exceptionalism of industrial policy in East Asia). 
and the "non-innovative" NICs. As will be argued later in this Article, the divide between innovative and non-innovative NICs results in sharp counterintuitive effects on each NIC's bargaining power over legal endowments and access conditions to intellectual property-based technologies.

\subsubsection{The Case of Bargaining Power in Pharmaceutical Patents}

The pharmaceutical industry is the prototypical patentsensitive industry; and for that reason, it serves well as a working example in which to apply the development inequality principle. In negotiations over patented products and technologies, the bargaining power of a developing country essentially hinges on three variables, namely, the country's outside option, inside options, and market power. First, the outside option represents the country's expected payoff in the absence of an agreement. The identification of the outside option is significant, for instance because reaching an agreement with a patentee may become unappealing if the alternative, the unilateral issuance of a compulsory license, is sufficiently attractive. ${ }^{91}$ Secondly, the developing country's bargaining power also depends on the availability of inside options. Under bargaining theory, inside options are the actions that a party may take in order to derive positive payoffs while temporarily disagreeing in the course of the bargaining process. ${ }^{92}$ An inside option differs from an outside option in that as a result of the latter negotiations break up and the parties stop bargaining, whereas the former assumes continued bargaining. ${ }^{93}$ Developing countries make use of an inside option, for instance, when they avoid de facto protecting IPRs while formally complying with TRIPS. ${ }^{94}$ Third, a developing

91 See Muthoo, Non-Technical Bargaining, supra note 14, at 159 (discussing the importance of the strength of outside options to bargaining power in the context of divorce).

92 See id. at 149, 157-60 (explaining, in the contexts of selling a home and divorce, how inside options would allow parties to continue bargaining while retaining benefits, whereas exercising outside options would terminate bargaining).

93 Abhinay Muthoo, BARgaining TheOry with Applications 137 (1999) [hereinafter Muthoo, BARGAINING THEORY] ("The payoff that the seller obtains while the parties temporarily disagree is her inside option. . . . In contrast, her outside option is the payoff she obtains if she chooses to permanently stop bargaining.").

94 See Robert M. Sherwood, The TRIPS Agreement: Implications for Developing Countries, 37 IDEA: J. L. \& TECH. 491, 495 (1997) [hereinafter Sherwood, The TRIPS Agreement] (describing how TRIPS requirements fall short of the robust protection 
country's bargaining power depends also on the extent of its market power, if any exists. A developing country purchasing a patented product or technology will be deemed to have market power insofar as it is able to profitably pay less than the competitive price. 95

\subsubsection{Outside Option: Instrumentality of Patent Compulsory Licenses}

In voluntary exchanges, a bargaining problem arises because the parties have to negotiate ex ante the allocation of the cooperative surplus that is expected to be generated ex post by their decision to cooperate. ${ }^{96}$ When this problem is not solved, mutual cooperation and agreement fails to take place. Bargaining theory commonly refers to this alternative as the "outside option," because it is the best alternative available for a country should it decide or be pushed to withdraw from negotiations. ${ }^{97}$ Naturally, to reach an agreement, each party must expect to receive a payoff higher than that of its outside option. ${ }^{98}$

In bargaining over the purchase price of pharmaceuticals, the issuance of a compulsory license can be viewed as an outside option available for developing countries. In this case, the payoff

necessary to encourage the highest levels of innovation in developing countries, however "full TRIPS implementation will give many developing countries a considerably improved ability to stimulate particular kinds of activity generally beneficial to national economic growth and development.").

95 See Org. For Econ. Development and Co-Operation, Roundtable on MONOPSONY AND BuYER POWER - NOTE by THE United STATES, DAF/COMP /WD(2008)79 at 3, available at http://www.ftc.gov/bc/international/ussubs .shtm (Oct. 13, 2008), [hereinafter ROUNDTABLE ON MONOPSONY] ("'[M]arket power' refers to the ability of a seller profitably to charge more than the competitive price for what it sells or to the ability of a buyer profitably to pay less than the competitive price for what it purchases.").

96 See, e.g., Robert D. Cooter \& Thomas Ulen, LAW \& ECONOMICS 78-80 (4th ed. 2004); Robert Cooter, The Cost of Coase, 11 J. LEGAL STUD. 1, 4 (1982) (discussing cooperative surplus). See generally THOMPSON, supra note 14 (describing negotiation strategies and behaviors).

97 See Muthoo, Non-Technical Bargaining, supra note 14, at 149, 154-60 (discussing how it is better for a bargainer to take the outside option when the bargainer's outside option is greater than the expected outcome of negotiations).

98 See COOTER, supra note 14, at 274 (describing how candidates in legislative elections must give the people what they want, or face the risk of having the people choose another candidate who will). 
represented by the issuance of a compulsory license is mainly a function of three variables. First, are the expected net savings that arise upon the issuance of the compulsory license; second, are the expected sanctions costs, which are the retaliatory costs that patentees and their home governments can impose on the country that issued compulsory licenses; and third, are the expected administrative costs associated with the more lax IP institutional framework suggested or created by the issuance of the compulsory license.

Net savings, the first variable determining the payoff represented by an outside option, are in reality the expected balance of direct costs and benefits that the country expects to obtain with the issuance of the compulsory license. A country issuing a compulsory license avoids the payment of royalties to the patent holder; but issuing a compulsory license will only be cost-effective if that country is able to either buy or produce the drugs at a lower cost. ${ }^{99}$ This first variable determining the outside option value tends to play out more favorably in larger and more industrialized developing countries, such as NICs. These countries potentially obtain larger net savings upon the issuance of a compulsory license primarily because they possess unique features that render them suitable places for the development of an indigenous generics production capacity. The term "generics" refers to drugs that can be obtained from multiple sources, as opposed to drugs that are sold only by the originator company or its exclusive licensees. ${ }^{100}$ The establishment of a viable and competitive generics pharmaceutical industry requires large consumer markets, local technical capacity, and proper manufacturing conditions. ${ }^{101}$ In addition, "[e]ven for

99 See Warren A. Kaplan \& Richard Laing, Local Production: Industrial Policy and Access To Medicines 1 (World Bank, HNP Discussion Papers, 2005) ("II]nvestments in local medicine production will be efficient only if pharmaceuticals can be produced more cheaply locally than they can be imported on the open market.").

100 See Andreas Seiter, Pharmaceuticals: Local Manufacturing 2 (World Bank, HNP Brief No. 3, 2005), available at http://siteresources.worldbank.org /HEALTHNUTRITIONANDPOPULATION/Resources/281627-1109774792596

/HNPBrief_3.pdf ("The term 'generic drugs' is used in this paper for all drugs that in principle can be obtained from multiple sources, as opposed to drugs that are sold only by the originator company or its exclusive licensees.").

101 See Rep. of the Secretariat of the World Health Org., Manufacture of Antiretrovirals in Developing Countries and Challenges for the Future, at 1, U.N. Doc. EB114/15 (Apr. 29, 2004), available at www.who.int/gb/ebwha/pdf_files 
generic drugs, some research and development is necessary for the manufacture of high-quality products, and the expenses and time incurred are often underestimated."102 Together, these considerations explain why a generics production capacity cannot be reproduced easily in most places in the world.

The availability of a generics manufacturing capacity can greatly increase the net savings of the country issuing a compulsory license. The reason for the increase is essentially that such a capacity lends credibility to the threat of issuing a compulsory license. Unlike the calls for distributive justice often put forth by countries with no such manufacturing capacity, 103 the ability to produce generics empowers a country to make use of compulsory licenses if and when necessary.104 In fact, for many years it "appeared that the only practical use of compulsory licenses was as a negotiating tool." 105 With a credible threat of compulsory drug licensing and the local manufacture of them, governments are able to press patent holders to grant large discounts on drugs. ${ }^{106}$

Generic medicines are typically priced at considerably lower rates than the brand drugs. ${ }^{107}$ As such, their availability generally

/EB114/B114_15-en.pdf [hereinafter World Health Report] ("Pharmaceutical plants need a huge initial capital outlay and take many years to construct; they tend to be located in countries with a good infrastructure, reliable utilities and access to technical expertise."). See also Kaplan \& Laing, supra note 99, at 34-35 (concluding that unless developing countries can obtain adequate production facilities, join with other small economies to create economies of scale, and manufacture with cost efficiency, it does not make sense for them to domestically produce medicines).

102 World Health Report, supra note 101, at 1.

103 See AmRITA NALIKAR, INTERNATIONAL TRADE AND DEVELOPING COUNTRIES: BARGAINING COALITIONS IN THE GATT AND WTO 77 (2003).

104 See, e.g., Peter K. Yu, Access to Medicines, BRICS Alliances, and Collective Action, 34 AM. J. L. \& MED. 345, 358 (2008) (detailing Brazil's threat to issue compulsory licenses for pharmaceutical patents).

105 See Brent Savoie, Thailand's Test: Compulsory Licensing in an Era of Epidemiologic Transition, 48 VA. J. INT'L L. 211, 238 (2007) (describing the history of compulsory licenses as a negotiating tool).

106 See Keith E. Maskus, Ensuring Access to Essential Medicines: Some Economic Considerations, 20 WIS. INT'L L.J. 563, 571 (2002) (noting that when there is a credible threat of compulsory license, pharmaceutical companies are more willing to negotiate price cuts in a purchasing agreement with governments).

107 But see Seiter, supra note 100, at 2 (stating that the prices of some local branded generics are equal to or higher than the price of originator product.) 
reduces a country's dependence on drugs supplied by big pharmaceutical companies. To illustrate, in Brazil, $56 \%$ of AIDS drugs distributed in 2001, commonly known as 'antiretrovirals' ("ARVs"), were locally produced. 108 While these drugs were not protected by patents, 109 their production as generics made possible a price reduction of $82 \%$ in the period between 1996 and 2001.110 Other countries have followed a similar path. For instance, "Thailand's Government Pharmaceutical Organization has been producing generic AZT for a quarter of the price of the brand name version for several years." 111

The case of Brazil illustrates how a local generics manufacturing capacity can serve as a powerful strategic tool to increase net savings through price negotiations. ${ }^{112}$ Brazil's state-owned laboratory, Far-Manguinhos, produces seven of the fifteen medicines used in the antiretroviral 'cocktail' freely offered in the country. ${ }^{113}$ The Brazilian government has largely premised its price negotiations with the international pharmaceutical industry on the credible threat of locally producing generics.114 Brazil repeatedly threatened to "issue compulsory licenses for AIDS medicines only to retract at the last minute after achieving what was widely per-

108 Alexandre Grangeiro et al., Sustentabilidade da Política de Acesso a Medicamentos Anti-Retrovirais no Brasil [Sustainability of Brazilian Policy for Access to Antiretroviral Drugs], in REvista DE SAúde PúBLICA 40, 60, 64 (2006).

109 Comm'n on IPR, supra note 54 at 43.

110 Grangeiro et al., supra note 108, at 64.

111 Judy Rein, International Governance through Trade Agreements: Patent Protection for Essential Medicines, 21 NW. J. INT'L L. \& BUS. 379, 402 (2001)

112 See Jorge A. Z. Bermudez et al., WhAT IS AT STAKE? INTELLECTUAL PROPERTY IN THE CONTEXT OF THE WTO TRIPS AGREEMENT: CHALLENEGES FOR PUBLIC HEALTH 36 (Jorge Bermudez \& Maria Oliveira eds., 2004) [hereinafter "CHALLENGES FOR PUBLIC HEALTH"] (detailing the benefit of compulsory licensing in negotiations between the U.S and Brazil). See also Comm'n on IPR, supra note 54, at 42-43 (noting how Brazil has been able to avoid costs).

113 Comm'n on IPR, supra note 54, at 43. For more information on FarManguinhos, which is a part of the Oswaldo Cruz Foundation-FIOCRUZ, a nonprofit research foundation linked to the Brazilian Ministry of Health, visit http://www.fiocruz.br.

114 Benjamin Coriat \& Fabienne Orsi, Pharmaceutical Patents, Generic Drugs and Public Health under the TRIPS Agreement, Background Paper to the Concluding Roundtable Discussion on IPR at the Druid Summer Conference 2003 on Creating, Sharing and Transferring Knowledge, 13 (Danish Research Unit for Industrial Dynamic, 2003) (demonstrating the importance of Brazil's capabilities to manufacture generic drugs to improve their bargaining position). 
ceived as a negotiation victory." 115 A recent study concluded that in the period from 2001 to 2005 Brazil saved approximately USD $\$ 1.2$ billion solely in ARVs used for treatment of infection by retroviruses, primarily HIV.116 In spite of its numerous threats, Brazil thus far has only issued one compulsory license, in 2007.

The second variable influencing a country's outside option relates to its expected sanctions costs. Generally speaking, these are the costs that may be imposed on a country that unilaterally breaks pharmaceutical patents. Big pharmaceutical companies often develop concerted efforts with their home governments in order to build a dual structure of sanctions costs. In the post-WTO twotiered patent bargaining framework, sanctions costs may come from governments of the developed world, in what is defined in this Article as Tier-1 sanctions, or from the pharmaceutical industry itself, in what is defined in this Article as Tier-2 sanctions.

An alleged breach of TRIPS may give rise to the submission of a complaint to the WTO. TRIPS rules on compulsory licenses are ambiguous as to what constitutes sufficient grounds authorizing the issuance of a compulsory license over pharmaceuticals, leaving an open flank that may be explored through litigation in most cases. ${ }^{117}$ The outcome of such litigation may be the authorization to impose trade sanctions on the country deemed to have acted illegally. ${ }^{118}$ Although the Doha Round broadened the legally acceptable scope of compulsory licensing, the possibility of authorization by the WTO to apply trade sanctions remains a tangible risk. The

115 Robert C. Bird \& Daniel R. Cahoy, The Emerging BRIC Economies: Lessons from Intellectual Property Negotiation and Enforcement, 5 NW. J. TECH. \& INTELL. ProP. 400, 421 (2007).

116 Amy S. Nunn et al., Evolution of Antiretroviral Drug Costs in Brazil in the Context of Free and Universal Access to AIDS Treatment, 4 PLOS MED 1803, 1804 (2007). See also Jane Galvão, Access to Antiretroviral Drugs in Brazil, 360 THE LANCET 1862, 1864 (2002) (illustrating how Brazil has used compulsory licensing as a bargaining tool).

117 See Thomas F. Cotter, Market Fundamentalism and the TRIPS Agreement, 22 CARDOZO ARTS \& ENT. L.J. 307, 334 (2004) (explaining that developing countries will not misuse their right in implementing compulsory licensing).

118 Id. See also Laurence R. Helfer, Regime Shifting: The TRIPs Agreement and New Dynamics of International Intellectual Property Lawmaking, 29 YALE J. INT'L L. 1, 5 (2004) (detailing the problems which TRIPS may pose to developing nations); G. Richard Shell, Trade Legalism and International Relations Theory: An Analysis of the World Trade Organization, 44 DUKE L.J. 829, 843-44 (1995) (explaining that the WTO has a system to enforce trade sanctions). 
dearth of case law by the DSB on the topic adds an additional element of uncertainty regarding the outcome of such litigation.

Government-imposed Tier-1 sanctions may also originate from unilateral state action. In recent decades, the United States took a leading role in attempting to shape and increase international patent protection. ${ }^{119}$ Even in the post-WTO era, the United States Trade Representative ("USTR") retains powers to act unilateral$1 y,{ }^{120}$ and uses them to persuade other countries, particularly developing countries, to enhance their intellectual property protection system. Such unilateral sanctions can be traced back to the mid-1970s, a period when intellectual property-sensitive industries pressed the United States government to set up an aggressive unilateral intellectual property agenda designed to curtail piracy and recover part of what were perceived to be unfair economic losses.121 Unilateral initiatives of this kind, however, remain a mostly non-legalized aspect of patent bargaining that takes place in the shadows of the WTO rule-based international system.

Similarly to net savings, trade sanctions also do not affect all developing countries in the same manner. ${ }^{122}$ Primarily, countries with more diversified economies tend to be less vulnerable to trade sanctions on specific products. ${ }^{123}$ In addition, some emerging

119 See Marney L. Cheek, The Limits of Informal Regulatory Cooperation in International Affairs: A Review of the Global Intellectual Property Regime, 33 GEO. WASH. INT'L L. REV. 277, 284 (2001) (explaining the strengthening protections for intellectual property rights).

120 See Omnibus Trade and Competitiveness Act of 1988, 19 U.S.C. § 2242 (2006).

121 See Cheek, supra note 119, at 292 (stating that USTR could impose sanctions if a country did not improve its intellectual property regime); Robert Krupka et al., Section 337 and the GATT: The Problem or the Solution? 42 AM. U. L. REV. 779, 783 (1993) (arguing that some countries want to eliminate remedies provided by section 377); Paul C. B. Liu, U.S. Industry's Influence on Intellectual Property Negotiations and Special 301 Actions, 13 UCLA PAC. BASIN L.J. 87, 89 (1994) (examining how U.S. industries affect the outcome of international intellectual property negotiations); Judith Bello \& Alan Holmer, "Special 301": Its Requirements, Implementation and Significance, 13 FordHAM INT'L L.J. 259, 259 (1989-90) (reviewing the implementation of special 301).

122 See Robert C. Bird, Defending Intellectual Property Rights in the BRIC Economies, 43 AM. BUs. L.J. 317, 334 (2006) (detailing how BRIC economies have coped with the threat of trade sanctions).

123 See Eyal Benvenisti \& George W. Downs, Distributive Politics and International Institutions: The Case of Drugs, 36 CASE W. RES. J. INT'L L. 21, 27 (2004) (dis- 
economies are large enough to pose a genuine threat of counterretaliatory trade sanctions imposed by developed countries. Such was noticeably the case in the dispute between the United States and China over the latter's intellectual property laws, a situation that in the mid-1990s almost led to a trade war.124 Another important aspect of trade sanctions is that as world powers compete for geopolitical influence, distinctive strategic advantages may reduce the prospects of employing sanctions among certain developing countries. ${ }^{125}$ To use the example of China again, during the aforementioned dispute, the United States bore a specific interest in preventing China from selling nuclear technology and equipment to Iran, Pakistan, and Algeria, which enhanced China's bargaining position. ${ }^{126}$

Aside from governments, the pharmaceutical industry itself may also be in a position to impose sanctions costs on countries that issue compulsory licenses. Compulsory licenses undermine the overall intellectual property protection system of a country, affecting IP-sensitive industries such as chemicals, computer soft-

cussing the importance of allowing developing nations the ability to access cheaper medicines).

124 See Assafa Endeshaw, A Critical Assessment of the U.S.-China Conflict on Intellectual Property, 6 ALB. L. J. SCI. \& TECH. 295, 318-19 (1996) (detailing China's ability to retaliate to U.S. sanctions); Peter K. Yu, From Pirates to Partners: Protecting Intellectual Property in China in the Twenty First Century, 50 AM. U. L. REV. 131, 142 (2000) (providing examples of how China has retaliated against the United States.); Richard J. Ansson, Jr., International Intellectual Property Rights, the United States, and the People's Republic of China, 13 TEMP. INT'L \& COMP. L.J. 1, 4 (1999) (examining the effect recent intellectual property negotiations have had on China visà-vis the United States).

125 See William P. Alford, How Theory Does-And Does Not-Matter: American Approaches to Intellectual Property Law in East Asia, 13 UCLA PAC. BASIN L.J. 8, 21-23 (1994) (explaining that applying external pressure to developing countries will not necessarily improve intellectual property protection). See also Barry E. Carter, International Economic Sanctions: Improving the Haphazard U.S. Legal Regime, 75 CAL. L. REV. 1162, 1162 (1987) (explaining how the United States' regime concerning sanctions on foreign governments requires reform); Martine de Koning, Why the Coercion-Based GATT Approach is Not the Only Answer to International Piracy in the AsiaPacific Region, 19 EUR. INTELl. Prop. REV. 59 (1997) (evaluating the United States' trade remedies).

126 See Carter, supra note 125, at 1174 n.40 (stating that the United States' restrictions on the export of nuclear technology to South Africa, India and Pakistan failed to convince those countries in accepting multilateral safeguards). 
ware, and pharmaceuticals. ${ }^{127}$ Pharmaceutical patentees that either are harmed by the licensing, or receive a credible threat of compulsory licensing of their patents, can retaliate in a number of ways. Depending on the circumstances, they can impose sanctions costs through reduced FDI, reduced technology transference and local $R \& D$, and reduced trade. ${ }^{128}$ In addition, and because innovation in pharmaceuticals is largely deemed to be patent-sensitive, a local pharmaceutical industry, while it exists, can also impose sanctions costs, most notably in the form of reduced innovation. In India, for example, the issuance of a compulsory license could send a disturbing signal to the innovation-prone sectors of its home pharmaceutical industry, which would probably be prompted to reduce innovation efforts. ${ }^{129}$ The example of India actually illustrates why the existence of an indigenous, innovative pharmaceutical industry can ironically impair the bargaining power of some developed countries, as will be further discussed later in this Article.

The extent of industry-sponsored sanctions costs, also referred herein as Tier-2 sanctions costs, are particularly difficult to predict. This is mainly because of the conceptual divide between static and dynamic efficiency, a theme that arises almost unavoidably in a discussion of patent policies. ${ }^{130}$ Effective patent protection entails a

127 See Gervais, supra note 43, at 523. See generally HA-JOON CHANG, Globalisation, ECONOMIC DeVElopmEnT AND tHE Role OF THE StATE 286-88 (2003) (discussing whether private intellectual property rights incentivize generation or disclosure of knowledge).

128 See Elhanan Helpman, Innovation, Imitation, and Intellectual Property Rights, 61 ECONOMETRICA 1247, 1249 (1993) (arguing that the analysis of intellectual property protection should be carried out through at least four dimensions, namely the terms of trade, the interregional location of manufacturing, product availability, and research and development investment patterns).

129 See Padmashree GeHl Sampath, Commisssion on InTellectual Property Rights, InNovation and Public Health, Economic Aspects of Access to Medicines After 2005: Product PATENT Protection AND EMERging Firm STRATEGIES IN THE INDIAN PHARMACEUTICAL INDUSTRY 5 (2005), available at http://www.who.int/intellectualproperty/studies/PadmashreeSampathFinal.pd $\mathrm{f}$ (stating that "emerging strategies of Indian firms will continue to be dictated mostly by survival needs and not by issues related to access to medicines of the general public, whether in India or other least developed countries").

130 See, e.g., J. M. Clark, Static Models and Dynamic Aspects, 45 AM. EcON. Rev. 450 (1955) (arguing that dynamic theory accepts indeterminateness of various kinds); Simon Kuznets, Static and Dynamic Economics, 20 AM. EcON. REV. 426 (1930) (also noting that the distinction was first introduced into economic theory by J. S. 
tradeoff between static losses arising from monopoly rents of patentees, and potential dynamic gains to society at large due to enhanced innovation. 131 The problem of industry-specific sanctions mirrors this discussion in that sanctions costs can be evaluated in terms of both welfare effects in equilibrium and welfare effects during the transition process toward equilibrium. ${ }^{132}$

Regardless of how Tier-2 sanctions costs are measured, middleincome developing countries are generally less likely to receive such sanctions than lower income countries. International pharmaceutical companies typically cannot afford to lose or alienate large markets that contain, or potentially contain, lucrative middle classes.133 A recent report by Price Waterhouse Coopers predicts that by 2020, Brazil, China, India, Indonesia, Mexico, Russia, and Turkey will represent one-fifth of global pharmaceutical sales, an increase of $60 \%$ since $2004 .{ }^{134}$ As the economy in these countries improves, local populations are expected to face the kinds of chronic health issues that are typical in wealthier countries. In addition, changes in environmental conditions may cause the spread of diseases that are more prevalent in the developing world such as cholera and malaria, among others. At the same time, longer life expectancy in these countries tends to influence drug sales positively.

The case of Brazil's intellectual property law illustrates the lower levels of vulnerability of NICs to Tier-2 sanctions. ${ }^{135}$ Brazil

Mill, who in his turn took it from Comte). See also CHANG, supra note 127, at 18490 (providing a more modern discussion); Anne O. Krueger, The Political Economy of the Rent-Seeking Society, 64 AM. ECON. REV. 291 (1974) (analyzing competitive rent seeking and its effect on an economy).

131 See Cooter \& Schaefer, supra note 44 , at 16 (justifying the grant of patents where the gains from increased inventions outweigh the temporary loss from monopoly pricing); WILLIAM D. NORDHAUS, INVENTION, GROWTH, AND WELFARE 70-71 (1969) (discussing the economics of a patent system).

132 See Alan O. Sykes, TRIPS, Pharmaceuticals, Developing Countries, and the Doha "Solution," 3 CHI. J. INT'L L. 47, 61-62 (2002) (discussing the economic welfare impact of pharmaceutical patents on developing countries).

133 Benvenisti \& Downs, supra note 123, at 27.

134 PriceWaterhoseCoopers, PHARMA 2020: THE VISION - WHICH PATH WILL YOU TAKE? (2007), available at http://www.pwc.com/gx/eng/about/ind/pharma /pharma2020final.pdf.

135 See generally Industrial Property Law of Brazil, Law No. 9279, May 14, 1996 (discussing Brazil's requirements and procedures for obtaining patents). 
enacted a TRIPS-compliant intellectual property law in 1997.136 The law then enacted, however, incorporated a number of TRIPS flexibilities and contained several mechanisms that left room for future compulsory licenses. For instance, the law included a "local working" provision which allows for subjecting a patent holder to compulsory licensing if, among other factors, she fails to manufacture the product within Brazilian territory. ${ }^{137}$ Upon the enactment of this law, the pharmaceutical industry issued a communiqué stating that any actions furthering the issuance of compulsory licenses would ensure that companies whose patents are violated would not sell their next generation AIDS drugs, or any other medication, in Brazil.138 Unimpressed by such threats from the pharmaceutical industry, Brazil continued to negotiate drug discounts from international pharmaceutical companies premised on a threat of its own, namely the prospects of issuance compulsory licenses. The Brazilian government finally issued a compulsory license in 2007; the realization of the pharmaceutical industry's retaliatory threats remains improbable.

Finally, a developing country's outside option depends on a third consideration. Aside from the net savings and the sanctions costs involved, the outside option is also a function of the effects of the issuance of a compulsory license on administrative costs, which operates in two ways. ${ }^{139}$ On one hand, a country issuing a compulsory license has, by definition, a less stringent intellectual property system. Thus, the compulsory license can be said to contribute to a reduction in the overall costs related to the administration of the intellectual property system. On the other hand, a country issuing

136 See Maria Auxiliadora Oliveira et al., Brazilian Intellectual Property Legislation, in CHALLENGES FOR PUBliC HeAlth 155, supra note 112 (noting however that under TRIPS, Brazil could have made use of a transition period but waived this prerogative).

137 Bird \& Cahoy, supra note 115.

138 See Ubirajara Regis Quintanilha Marques et al., Brazil's AIDS Controversy: Antiretroviral Drugs, Breaking Patents, and Compulsory Licensing, 60 FOOD \& DRUG L.J. 471, 474 n.26, 476 (2005) (discussing Brazil's threats of compulsory pharmaceutical patents licenses and the industry's response).

139 See James Love, Access to Medicine and Compliance with the WTO TRIPS Accord: Models for State Practice in Developing Countries, in GLOBAL INTELLECTUAL PROPERTY Rights: KNOWLEDGE, ACCESS AND DEVELOPMENT 74, 75-77 (Peter Drahos \& Ruth Mayne eds., 2002) (noting that the TRIPS Agreement is flexible in allowing compulsory patent licenses and that litigation costs can be prohibitive). 
a compulsory license faces the risk of incurring costly litigation, a meaningful consideration for poorer developing countries. ${ }^{140}$ This risk of litigation is enhanced by the fact that, under TRIPS, applications for compulsory licenses must be considered on their individual merits. ${ }^{141}$ Taking both sides into account, the net impact of the issuance of a compulsory license on administrative costs is not only difficult to measure but also difficult to predict. ${ }^{142}$ However, it is clear that litigation costs at WTO's DSB can be a deterrent only for smaller and poorer developing countries. ${ }^{143}$

\subsubsection{Inside Options: National Opportunism Within TRIPS}

The outcome of a bargaining process, although constrained by the outside option, is also determined by the inside options available to the parties. Inside options are actions that provide positive payoffs while bargaining is still underway. Inside options are therefore resources available to the parties during the course of negotiations. ${ }^{144}$ A desirable outside option demonstrates why a developing country can genuinely threaten to terminate cooperation with patentees if it is solely able to obtain a larger payoff through

140 See Cotter, supra note 117. See also Gregory Shaffer, Recognizing Public Goods in WTO Dispute Settlement: Who Participates? Who Decides? The Case of TRIPS and Pharmaceutical Patent Protection, 7 J. INT'L ECON. L. 459, 471-72 (2004) (describing how developed countries can influence the decisions of developing countries and force settlements due to high litigation costs).

141 See Agreement on Trade-Related Aspects of Intellectual Property Rights, Apr. 15, 1994, Marrakesh Agreement Establishing the World Trade Organization, Annex 1C, in The Legal Texts: The Results of the Uruguay Round of Multilateral Trade Negotiations 333 (1999), 1869 U.N.T.S. 299, 33 I.L.M. 1197 (1994).

142 See Carlos M. Correa, New International Standards for Intellectual Property: Impact on Technology Flows and Innovation in Developing Countries, 24 SCI. \& PUB. POL'Y 79, 85 (1997) (discussing administrative costs of implementing the TRIPS Agreement).

143 Cf. Paul Rothstein, Moving All-In with the World Trade Organization: Ignoring Adverse Rulings and Gambling With The Future of the WTO, 37 GA. J. INT'L \& COMP. L. 151, 166-67 n.95 (2008) (noting that larger countries, unlike developing countries, can afford litigation expenses but that developing countries can gain leverage by the threat of litigation).

144 See Jon Elster, Arguing and Bargaining in Two Constituent Assemblies, 2 U. PA. J. CONST. L. 345, 399-400 (2000) (stating that desirable inside options bolster the credibility of a party's threat to temporarily stop bargaining, providing that party with greater bargaining power). 
the issuance of a compulsory license. Conversely, the availability of desirable inside options shows why a developing country can credibly threaten to temporarily suspend or prolong negotiations in order to hold out for a better offer. ${ }^{145}$

A compulsory license can function both as an outside option and as an inside option. As described in the previous subsection, at a Tier-2 level, the level in which developing countries negotiate with the pharmaceutical industry over drug prices, inter alia, the compulsory license is the outside option par excellence. As was shown earlier, the issuance of a compulsory license typically reflects the preferred option of a developing country when negotiations with patentees break down. Yet, the issuance of a compulsory license can work as an inside option as well. In order to understand why, consider the Tier-1 level negotiations in which countries bargain over the legal endowments that will be set forth under domestic and international intellectual property laws. During the course of such negotiations, the issuance of a compulsory license potentially permits a country to obtain a positive payoff without leaving the negotiations table, where a legal endowment may be at stake. For instance, during the course of the negotiations within the Doha Round, some developing countries indeed threatened to issue compulsory licenses while not leaving the negotiations table at the WTO.

There are several additional inside options available for developing countries. The ability of a developing country to make use of inside options, however, is to a large extent dependent upon the specific tenets of its national patent laws and regulations. While the dominant legal rules affecting intellectual property systems are essentially extra-territorial in nature, the incorporation of TRIPS flexibilities by each country is not mandatory and has to be established under domestic laws. ${ }^{146}$ Each state adjusts international standards to its own intellectual property policies and establishes

145 Id. See also Muthoo, Non-Technial Bargaining, supra note 14, at 149, 157-60 (explaining that someone selling a house can exercise the inside option of remaining in the house until he or she can agree on a sale price with a buyer).

146 See J.H. Reichman \& David Lange, Bargaining Around the Trips Agreement: The Case for Ongoing Public-Private Initiatives to Facilitate Worldwide Intellectual Property Transactions, 9 DUKE J. COMP. \& INT'L L. 11, 62 (1998) (positing that the implementation of legal rules for intellectual property systems varies widely between countries). 
their enforcement level, thereby setting the ground for a bargaining process in which political actors at the national and supranational level lobby in order to influence lawmaking at the national level. ${ }^{147}$ Nevertheless, recent studies have shown that many developing countries failed to fully incorporate TRIPS' flexibilities into their national patent legislation, reducing the available inside options. ${ }^{148}$

TRIPS indeed contains authorizations for a number of outside options that may be utilized by developing countries. First, in some cases developing countries can hinder patenting by foreigners through discrete changes in legislation that are expressly permitted under TRIPS. Second, it is possible to narrow the legal definition of patentability, or simply deny patentability altogether, for certain categories of products such as plants and animals. ${ }^{149}$

147 See Benvenisti \& Downs, supra note 123, at 29 (describing the bargaining between South Korea and the drug maker for a reduced price for an anti-leukemia drug after the United States lobbied to have an application for compulsory licensing denied).

148 See Rep. of the Secretariat, Antiretrovirals and Developing Countries, 15 , U.N. Doc. EB 115/32 (Dec. 16, 2004) (stating that recent studies have shown that some Latin American countries have not used all of the flexibilities granted by TRIPS); B. K. Keayla, Regional Office for South-East Asia, Review of National Patent Legislations of India, Indonesia, Sri Lanka \& Thailand: Measures to Safeguard Public Health (World Health Org. Sept. 2004), available at http://www.searo.who.int /LinkFiles/Reports_HSD-275-Patent.pdf (stating that India, Indonesia, Sri Lanka and Thailand have not fully taken advantage of licensing arrangements allowed under TRIPS); S. Moon, Implementation of the Doha Declaration on the TRIPS Agreement and Public Health: Technical Assistance - How to Get it Right (Médecins Sans Frontières), available at http://www.eldis.org /assets/Docs/12075.html (discussing "specifics of the Declaration, including how to resolve the "production-forexport' issue and put compulsory licensing into practice")Phil Thorpe, Study on the Implementation of the TRIPS Agreement by Developing Countries 1 (Comm'n on Intell. Prop. Rights, Study Paper No. 7, 2002), available at http://www.iprcommission.org/papers/pdfs/study_papers/sp7_thorpe_study. pdf (noting that developing countries have not yet taken full advantage of the flexibilities offered by TRIPS); Maria Auxiliadora Oliveira et al., Has the Implementation of the TRIPS Agreement in Latin America and the Caribbean Produced Intellectual Property Legislation that Favors Public Health? 82 Bulletin OF THE WORLD HeAlTH ORG. 815, 818-19 (2004) (concluding that a number of Latin American countries did not incorporate all of the mechanisms permitted by TRIPS in order to promote public health to the best extent possible);

149 One exception is for micro-organisms. See TRIPS Agreement, supra note 16, art. 27(3)(b) (excluding plants and animals from the scope of patentable materials, apart from micro-organisms). See also JAYASHREE WATAL, INTELLECTUAL PROPERTY RIGHTS IN THE WTO AND DEVELOPING COUNTRIES 93 (2001) (noting that countries may exercise discretion over what inventions may be patented). 
Third, a country can emphasize the doctrine of prior user's rights in order to lower licensing costs. ${ }^{150}$ This doctrine offers a personal defense for someone who non-publicly uses an invention undergoing the patenting process by another, and permits the prior user to continue using the invention. Its practical effect is to authorize a party other than the patentee to continue usage of an invention that was created by the time the patentee's application was filed. ${ }^{151}$ A fourth inside option available to a developing country is the imposition of supplementary disclosure obligations on patentees. ${ }^{152}$ TRIPS authorizes a country to establish duties to disclose the origin of plant genetic resources used in an invention, 153 to compel the patent offices to publish the application for a patent shortly after its submission, 154 or to require that a patentee reveal the "best mode" for practicing the invention. ${ }^{155}$ A best mode provision requires the patent applicant to disclose the specific embodiment of the invention, thereby prohibiting inventors from disclosing only what they consider their second-best embodiment, while retaining the best for themselves. ${ }^{156}$ Other inside options available for developing

150 Paul J. Heald, Mowing the Playing Field: Addressing Information Distortion and Asymmetry in the TRIPS Game, 88 MiNN. L. REV. 249, 280 (2003).

151 See id. at 280 (stating that the prior user's doctrine would allow an existing use of a patented invention by a non-patent holder to continue).

152 See TRIPS Agreement, supra note 16, art. 62(1) (authorizing members to "require, as a condition of the acquisition or maintenance of the intellectual property rights ... compliance with reasonable procedures and formalities.").

153 See Nuno Pires de Carvalho, Requiring Disclosure of the Origin of Genetic Resources and Prior Informed Consent in Patent Applications Without Infringing the TRIPS Agreement: The Problem and the Solution, 2 WASH. U. J.L. \& POL'y 371, 372 (2000) (" [W] hat is at stake is the possibility of detecting commercial gains from the use of genetic resources, so that countries supplying those resources can demand their share in the benefits.").

154 See Heald, supra note 150, at 283 ("[S]ome patent offices publish the application for a patent very soon after [filing].").

155 See TRIPS Agreement, supra note 16, art. 29(1) ("Members . . . may require the applicant to indicate the best mode for carrying out the invention known to the inventor at the filing date or, where priority is claimed, at the priority date of the application."); J.H. Reichman, From Free Riders to Fair Followers: Global Competition Under the TRIPS Agreement, 29 N.Y.U. J. INT'L L. \& POL. 11, 33 (1997) (defending the implementation of the best mode requirement).

156 See In re Nelson, 280 F.2d 172 (C.C.P.A. 1960) (granting a patent application because the applicants had explicitly disclosed the best use of the pharmaceutical as required under the best mode provision of 35 U.S.C. \$112). See also Eli Lilly \& Co. v. Barr Labs. Inc., 251 F.3d 955, 963 (D.C. Cir. 2001) (“The best mode 
countries under TRIPS include the use of counterbalancing regulatory measures in competition law, 157 or the use of safeguards permitted within the TRIPS Agreement. 158

A number of more commonly controversial inside option policies exist as well. The TRIPS Agreement does not stipulate exceptions to the patent rights it protects. ${ }^{159}$ As a result, developing countries are able to deviously discourage patent applications by foreign firms by pursuing myriad alternatives, such as making the process of patenting overly costly, lengthy, and bureaucratic, ${ }^{160}$ or simply taking advantage of (and failing to improve) its judicial system. The latter alternative is closely related to the much broader context of failures in the rule of law, 161 a familiar trait amongst developing countries. ${ }^{162}$ All of these alternatives avoid de facto pro-

requirement creates a statutory bargained-for-exchange by which a patentee obtains the right to exclude others from practicing the claimed invention for a certain time period, and the public receives knowledge of the preferred embodiments for practicing the claimed invention.").

157 See TRIPS Agreement, supra note 16, art. 40(2) ("Nothing in this agreement shall prevent Members from specifying in their legislation licensing practices or conditions that may in particular cases constitute an abuse of intellectual property rights having an adverse effect on competition in the relevant market.").

158 See TRIPS Agreement, supra note 16, art. 7 (setting out the purpose of TRIPS as the promotion of mutual advantages for both producers and users of intellectual property).

159 See Reichman \& Lange, supra note 146, at 21; Frederick M. Abbott, The WTO TRIPS Agreement and Global Economic Development, 72 CHI.-KENT L. REV. 385, 399 (1996) (discussing the technological disparity between countries under TRIPS); Rochelle Cooper Dreyfuss \& Andreas F. Lowenfeld, Two Achievements of the Uruguay Round: Putting TRIPS and Dispute Settlement Together, 37 VA. J. INT'L L. 275 (1997) (arguing that intellectual property law must be predictable to be effective, and proposing ways to codify the TRIPS Agreement); J.H. Reichman, supra note 155 , at 34 .

160 Heald, supra note 150, at 250-51.

161 See Sherwood, The TRIPS Agreement, supra note 94, at 493; see also Arie Reich, From Diplomacy to Law: The Juridicization of International Trade Relations, 17 NW. J. INT'L L. \& BUS. 775, 805 (1997) (hypothesizing that the new GATT appellate body can correct some of the previous problems in GATT rule of law); Luciana Gross S. Cunha, Rule of Law and Development: The Discourses on Institutional Reforms in the Justice System (Artigos Direito GV, Working Paper No. 21, 2009), available at http://www.direitogv.com.br/interna.aspx?PagId=HTKCNKWI\&IDCategory=2 $6 \& I D S u b C a t e g o r y=146$ (explaining different concepts of the rule of law).

162 See Cooter \& Schaefer, supra note 44, at 16-19; Richard A. Posner, Creating a Legal Framework for Economic Development, 13 The World Bank Research Observer 1 (1998) (explaining how poorer nations have less property enforcement, which 
tection of intellectual property rights, while formally complying with TRIPS. 163

In conclusion, the availability of inside options increase the bargaining power of developing countries by increasing their willingness to enter into an agreement with patentees and their home governments. ${ }^{164}$ In addition, the availability of inside options may reduce the short-term costs of compliance with the patent sections of the TRIPS Agreement, both by rendering patenting less attractive and by creating the conditions for a reduction in costs to consumers of patented products. 165 From the developing country's perspective, the goal of discouraging foreign patenting is twofold. It aims at seizing the positive welfare effects offered by intellectual property laws, while at the same time reducing the cost to consumers and local industry of complying with the TRIPS Agreement. All of this may be accomplished without deliberately breaching TRIPS. What is more, this scheme/system often allows a developing country to recapitulate some of the rewards of foreign innovation while bearing as little of the cost as possible. ${ }^{166}$

\subsubsection{Market Power: Competition and Substitutes}

Finally, a developing country's bargaining power is dependent on the extent of its market power, should it bear any. In both economics and law, market power generally refers to the ability of a seller to profitably charge more than the competitive price for what it sells, or the ability of a buyer to profitably pay less than the com-

allows richer nations to take advantage); Maria Dakolias, The Judicial Sector in Latin America and the Caribbean: Elements of Reform (World Bank, Technical Paper No. $319,1996)$ (proposing judicial changes to strengthen property rights); Robert J. Barro, Economic Growth in a Cross Section of Countries, 106 THE Q. J. OF ECON. 407 (1991) (explaining growth rates and factors for developing countries).

163 Sherwood, The TRIPS Agreement, supra note 94, at 544.

164 Muthoo, Non-Technical Bargaining Power, supra note 14, at 148-52.

165 Heald, supra note 150 , at 250.

166 The Preamble of the TRIPS Agreement suggests this option and the merits of flexibility are trumpeted by the WTO itself. See TRIPS Agreement, supra note 16, at $18(1)$ ("Members may, in formulating or amending their laws and regulations, adopt measures necessary to protect public health and nutrition, and to promote the public interest in sectors of vital importance to their socio-economic and technological development, provided that such measures are consistent with the provisions of this Agreement."). 
petitive price for what it purchases. ${ }^{167}$ In the case of pharmaceutical patents, market power would express itself in the ability on the part of a developing country buying a patented drug to gainfully pay less than the competitive price. 168 Conversely, existing data suggests that situations such as this are quite rare. The average wholesale drug prices are almost as high in developing as in developed countries, notwithstanding the fact that incomes are much higher in the latter. ${ }^{169}$ This data intimates that the market power of the overall group of developing countries is low. ${ }^{170}$ Similarly, a software industry requires an innovative-based infrastructure, such as electricity, computers and networks. This in turn requires an educated labor force. In addition, the developing country must already value intellectual property as a sellable commodity in order for a software industry to materialize. Because software is such an advanced form of trade, LBPs, especially African ones, are far from developing any profitable industry, let alone a profitable software industry. ${ }^{171}$ When viewed as a monolithic group, developing countries can be considered "price-takers." 172

Yet, market power fundamentally varies among developing countries. First, the availability of an indigenous pharmaceutical industry can serve as a powerful instrument for engendering competition among drug suppliers at the national level. ${ }^{173}$ Second, the

167 See RoundTABLE ON MONOPSONY, supra note 95, at 7.

168 Id.

169 Maskus, supra note 106, at 566; see F. M. Scherer \& Jayashree Watal, PostTRIPS Options for Access to Patented Medicines in Developing Countries 8-10 (World Health Org. Comm'n on Macroecon. \& Health, Working Paper No. WG4: 1, 2001) (analyzing drug pricing in the absence of patent protection).

170 See Maskus, supra note 106, at 566 (offering several reasons for why drug prices might be high in developing countries); Scherer \& Watal, supra note 169, at 49-53 (analyzing price controls in developing and developed countries)

171 See Mary Kopczynski, Robin Hood Versus the Bullies: Software Piracy and Developing Countries, 33 RUTGERS COMPUTER \& TECH L.J. 299 (2007) (explaining that developing countries feel they are being bullied by developed countries, and thus resort to "Robin Hood" schemes).

172 See, e.g., Ministério DA SAÚdE \& MinISTÉRIO DO DESENVOLVIMENTO, INDÚSTRIA E COMÉRCIO EXTERIOR, FÓRUM DE COMPETITIVIDADE DA ÇADEIA PRODUTIVA FARMACÊUTICA 2003-2006: O DESAFIO DE PROSSEGUIR (2007) [hereinafter, FÓRUM DE COMPETITIVIDADE] (discussing the pharmaceutical industry in Brazil).

173 See C.P. Chandrasekhar \& Jayati Ghosh, WTO Drugs Deal: Does it Really Benefit Developing Countries?, THE HINDU Bus. LinE: INTERNET EDITION (Sept. 9, 2003), http://www.blonnet.com/2003/09/09/stories/2003090900140900.htm 
developing country's market power depends equally on its purchase volume, so developing countries with larger consumer markets tend to levy more market power. ${ }^{174}$ Third, in wealthier developing countries a sizeable share of the population will be covered by either public or private health insurance. Governments or insurance companies in these countries will respond to a larger demand, which could allow them to negotiate larger price discounts. ${ }^{175}$ In addition, a buyer's market power also depends on factors such as the availability of information and of substitute products, the buyer's price sensitivity, and the differential advantage of the products, all of which highlights the importance local factors. 176

In sum, measuring bargaining power is tricky. Relative market size typically offers the best preliminary assessment tool, but a more comprehensive understanding requires taking into account other considerations that shape a country's outside option, inside options, and market power. ${ }^{177}$ In the post-WTO era, trade and intellectual property have merged into a single bargaining legal and institutional framework. For that reason, international patent regulation became necessarily entangled within a broader agenda of trade liberalization, foreign investment, and innovation policies. ${ }^{178}$ This dynamic emphasizes the greater bargaining power of those countries that fulfill the intermediary stages in the interna-

(suggesting that, in regard to protecting developing countries, the TRIPS Agreement does not deserve the "extravagant and fulsome praise" heaped upon it).

174 Benvenisti \& Downs, supra note 123, at 44 (discussing the strengths and weaknesses of "middle income" developing countries' market position).

175 See Maskus, supra note 106, at 566 (noting that countries with smaller populations will not be able to "win price discounts"); see also WORLD HEALTH OrG. COMm'n on Macroecon. And Health, HeAlth and the InTERnational ECONOMY 49 (2002) (discussing various ways to improve developing countries' access to pharmaceuticals).

176 See generally Michael E. PORTER, COMPeTITIVE STRATEgy 108-22 (1980) (detailing the factors which affect buyers' strategy).

177 See generally Steinberg, supra note 11, at 347-48 (discussing "market size as a source of bargaining power at the GATT/WTO").

178 See generally Frederick M. Abbott, Protecting First World Assets in the Third World: Intellectual Property Negotiations in the GATT Multilateral Framework, 22 VAND. J. TRANSNAT'L L. 689 (1989) (“[T]he Unites States has threatened or imposed coercive economic measures on countries it regards as not providing adequate [patent] protection."). 
tional division of labor and industrial production, such as NICs. ${ }^{179}$ At the same time, the propensity to innovate can sharply change the ability of developing countries to issue compulsory licenses, as will be argued in the next section.

\section{THE INNOVATION BENT OVER THE BARGAINING COST STRUCTURE}

\subsection{Overview}

Insofar as the ability to issue compulsory licenses is concerned, the post-WTO intellectual property-based bargaining environment requires a conceptual adaptation of existing bargaining models. Tables 1 and 2 depict graphically the suggested shift. Table 1 represents the standard view that WTO members negotiate market access and other commitments essentially on the size and diversity of their economies. ${ }^{180}$ The assumption is that the members with the highest economic wealth and most diversified economies have more bargaining chips to offer, and less to lose, should negotiations break down. Bargaining power is therefore viewed as a continuum that largely reflects market size and economic diversification. 181 In contrast, as depicted in Table 2, this Article argues for a more nuanced view of bargaining power within the group of developing countries when intellectual property-based products and technologies are at stake. This nuanced view takes into account the overall higher levels of bargaining power of NICs in comparison with the rest of the group of developing countries, but it also considers the effects of varied levels of innovativeness in pharmaceuti-

179 See generally Bradford Jr., supra note 82 (examining how the United States and Western Europe will adjust to the NICs' role as global exporters); CHOWDHURY \& ISLAM, supra note 81 (commenting on the rise of four NICs, Hong Kong, Korea, Singapore, and Taiwan); GuILLÉN, supra note 82 (noting the globalization's dependence on economic growth).

180 See Richard H. Steinberg, Trade-Environment Negotiations in the EU, NAFTA, and the WTO: Regional Trajectories of Rule Development, 91 AM. J. INT'L L. 231, 233 (1997) (comparing bargaining positions of different countries and the factors which effect those positions); Gerhart \& Kella, supra note 4, at 522 ("The position of developing countries in the WTO is as much a reflection of their lack of power as it is a reflection of their economic interests of integrating capacities.").

181 See Steinberg, supra note 11, at 341 ("When GATT/WTO bargaining is power-based, states bring to bear instruments of power that are extrinsic to the rules (instruments based primarily on market size) ...."). 
cals within the group of NICs. A typology emerges to divide developing countries into three groups. As will be explained, innovative NICs are categorized as Medium Bargaining Power countries ("MBPs"), and non-innovative NICs are categorized, somewhat paradoxically, as High Bargaining Power Countries ("HBPs"). The remaining developing countries are represented collectively as Low Bargaining Power Countries (“LBPs”).

Table 1: Conventional WTO Bargaining Model

\begin{tabular}{|c|c|c|}
\hline $\begin{array}{l}\text { Least Developing } \\
\text { Countries (LDCs) }\end{array}$ & $\begin{array}{l}\text { Developing } \\
\text { Countries }\end{array}$ & $\begin{array}{c}\text { Developed } \\
\text { Countries }\end{array}$ \\
\hline 50 poorest countries & [Default List] & Most OECDs \\
\hline
\end{tabular}

Table 2: Suggested Post-WTO Bargaining Model

\begin{tabular}{|c|c|c|c|}
\hline LBPs & $\begin{array}{l}\text { MBPs (Inno- } \\
\text { vative NICs) }\end{array}$ & $\begin{array}{c}\text { HBPs (Non- } \\
\text { Innovative NICs) }\end{array}$ & $\begin{array}{l}\text { Developed } \\
\text { Countries }\end{array}$ \\
\hline $\begin{array}{l}\text { Developing Countries } \\
\text { [Default List] }\end{array}$ & China, India & $\begin{array}{c}\text { Brazil, South Africa, } \\
\text { Thailand }\end{array}$ & Most OECDs \\
\hline
\end{tabular}

The presence of innovation in pharmaceuticals, particularly, serves as a threshold between two groups of NICs. These groups are the innovation 'haves,' sometimes referred to as 'innovative developing countries,' 182 and the innovation 'have-nots.' 183 Currently, only two NICs are undergoing the process of becoming pharmaceutical innovators. This small group of innovative NICs effectively includes only India and China. To be sure, this transition is clearer in India, which already displays robust signals of pharmaceutical innovativeness. In China, though, there are indications that the

182 See Carlos Morel et al., Health Innovation in Developing Countries to Address Diseases of the Poor, 1 InNOvation STRATEgy TODAy 1, 2 (2005) ("IDCs have the capacity to develop, manufacture, ensure safety, and market new health products and to develop, test and introduce new health policies or strategies.").

183 See Ulku, supra note 49, at 20 (noting that market size is an important factor in determining the effectiveness of Research \& Development sectors). 
country's innovative industry is just as promising. In this group of countries, pharmaceutical innovation plays a twofold role. On the one hand, it boosts the countries' technology-based economies, rendering them more competitive and efficient. ${ }^{184}$ On the other hand, pharmaceutical innovation restricts the ability of their governments to issue compulsory licenses that would make drugs more affordable to their needy and sizeable populations. ${ }^{185}$

In 'innovative NICs,' or MBPs, the issuance of compulsory licenses entails Tier-2 sanctions costs, that is to say, sanctions costs imposed by the pharmaceutical industry. The issuance of a compulsory license signals the existence of a less protective intellectual property system. In MBPs, the booming local pharmaceutical industry would be prompted to reduce innovation efforts out of fear that a less protective legal and institutional environment would be available to future pharmaceutical inventions. Such a reaction would certainly be the case for both the national pharmaceutical industry, as may be seen prominently in India, and for international MNEs performing R\&D activities abroad, as is increasingly common in both India and China.

Conversely, 'non-innovative NICs,' or HBPs, neither innovate, nor foresee becoming relevant pharmaceutical innovators in the immediate future. Brazil ${ }^{186}$ and Thailand ${ }^{187}$ clearly qualify as HBPs, while South Africa is a threshold, or dubious, case. ${ }^{188}$ Countries such as Brazil and Thailand are like China and India-

184 See generally Shahid Yusuf, From Creativity to Innovation (World Bank, Working Paper No. 4262, 2007) (arguing that "[c]ommercially viable innovations" are increasingly important to a country's economy).

185 See, e.g., Overview of HIV and AIDS in India, AvERT, http:/ / www.avert.org/aidsindia.htm (last visited Oct. 19, 2010) (outlining the effects of AIDS in India); HIV $\mathcal{E}$ AIDS in China, AvERT, http://www.avert.org/aidschina.htm (last visited Oct. 19, 2010) (describing the prevalence of AIDS in China).

186 See FóRUM DE COMPETITIVIDADE, supra note 172, at 77 (discussing Brazil's technical innovations)

187 See Savoie, supra note 105 (discussing the effects of compulsory licensing on Thailand's innovativeness); see also Daniel R. Cahoy, Confronting Myths And Myopia on the Road from Doha, 42 GA. L. REV. 131, 172-192 (2007) (discussing how compulsory patent licensing can both reward innovation and provide increased access to medicines)

188 Sykes, supra note 132, at 47-48 ("South Africa was the target of litigation initiated by a number of pharmaceutical manufacturers over South Africa's Medicines and Related Substances Control Act of 1997."). 
although on a smaller scale -in that they possess great bargaining power because of their large and diversified economies. Therefore, it may be proffered that HBPs are at best mildly fearful of Tier-1 sanctions costs. However, because HBPs are non-innovative countries, the risk of industry-specific sanctions costs, or Tier-2 sanctions costs, is minimal. In these countries, a much less innovative pharmaceutical industry will be unable to impose sanctions costs through reduced innovation.

\subsection{The HBP Model: A Single-Sanction Cost Structure}

\subsubsection{Introduction}

Among HBPs, overall weaker players are in a more favorable position to bargain than players who are stronger overall - a situation which is, at first glance, paradoxical. HBPs like Brazil and Thailand generally possess less market power than larger developing countries like India and China; yet in the context of intellectual property bargaining they are stronger than the latter countries because of their ability to issue compulsory licenses. Similarly, the most innovative applications of a government's use of open source technology stem from HBPs. ${ }^{189}$ Examples include: Citizen Service Centres in Brazil, ICT-based Electoral Reform in South Africa, and Philippine Customs Reform. "Innovative solutions based on opensource technologies enable faster diffusion of locally-innovated ICT."190 The group of HBPs is composed of those countries that stand to benefit the most from bargaining around TRIPS through patent compulsory licensing. Their high bargaining power is essentially to the result of three features. First, they are NICs, which implies relatively higher market power than developing countries at large. Second, they do not innovate in pharmaceuticals and thus have lower innovation-related sanction costs. Third, their current domestic laws contain limited TRIPS-plus provisions.

189 Cf. Free Software in Developing Countries Vital to Future Prosperity and Good Governance: UNU Technology Experts, UNITED NATIONS UNIV. (Mar. 15, 2006), http://www.unu.edu/media/archives/2006/files/mre-iist-3-06.pdf [hereinafter Free Software in Developing Countries] (discussing the development of better open source desktops and increasing the number of open source programmers).

190 Id. 
This third point deserves highlighting and further explanation. Not every non-innovative NIC can be considered an HBP. Mexico, for instance, a large non-innovative NIC, has a fairly limited ability to bargain with either developed countries or the pharmaceutical industry. Mexico is bound by the North American Free Trade Agreement ("NAFTA") 191 and by an FTA, which it signed with the European Union in the year 2000.192 These agreements can render illegal issuances of compulsory licenses that would be legal under TRIPS alone. As such, these agreements magnify the prospects of Tier-1 sanctions in the event compulsory licenses are issued.

\subsubsection{The HBP-MBP Regional Thresholds}

\subsubsection{Brazil/South America}

The case of Brazil shows that the absence of local innovation in pharmaceuticals can, ironically, boost the bargaining power of a large developing country. For decades, Brazil has been a leading voice for the developing world, in South America and beyond, in international trade and intellectual property disputes. As such, it has opportunistically funneled its commercial interests into an aggressive form of bargaining with developed countries.

Brazil is herein categorized as an HBP primarily because it has a high value outside option in negotiations over the conditions for access to patented pharmaceuticals. This outside option is available to Brazil firstly because the country possesses a generics industry that is in a position to produce patented drugs that may be compelled to obtain compulsory licenses. Since the issuance of compulsory licenses in Brazil can generate net savings, threats of compulsory licensing become a powerful negotiation weapon.

191 See generally North American Free Trade Agreement, U.S.-Can.-Mex., Dec. 17, 1992, 32 I.L.M. 289, 670 (1993) (discussing the standard of protection for intellectual property rights per the agreement).

192 See generally Economic Partnership, Political Coordination and Cooperation Agreement between the European Community and its Member States, of the one part, and the United Mexican States, of the other part, Oct. 28, 2000, 2165 U.N.T.S. 111 (intending to "establish a framework to encourage the development of trade in goods and services"); see also Bryan Mercurio, TRIPS-Plus Provisions in FTAs: Recent Trends, in REgIONAL TRAdE AgREEMENTS AND THE WTO LEGAL SYSTEM 215, 221 n.24 (Lorand Bartels \& Federico Ortino eds., 2006) ("Mexico has FTAs with over 42 countries, many of which were negotiated subsequent to NAFTA."). 
Second, a non-innovative NIC like Brazil faces a combination of mild to low Tier-1 and Tier-2 sanctions costs. On a Tier-1 level, Brazil's large and diversified economy grants the country the ability to endure retaliation threats from the developed world. On a Tier-2 level, Brazil's large and growing consumer markets guarantee reasonable to high private investment levels in production. ${ }^{193}$ At the same time, a less stringent patent regime does not sufficiently harm its largely non-innovative pharmaceutical industry. ${ }^{194}$ Third, a NIC such as Brazil can withstand the prospects of costly litigation upon the issuance of compulsory licenses.

All of these factors have contributed to shaping Brazil's aggressive bargaining behavior. ${ }^{195}$ Brazil has also gained world renown for being the most successful developing country in tackling the AIDS epidemic. ${ }^{196}$ Key to the effectiveness of Brazil's AIDS program was the country's aggressive negotiating stance designed to obtain large discounts on HIV/ AIDS medication produced by big pharmaceutical companies. Its strategy was largely premised on the issuance of compulsory licenses, or the threat thereof, on patent rights over these drugs. ${ }^{197}$

193 See Steve Hamm, Tech's Future, Bus. WK., Sept. 27, 2004, at 82 (discussing the growth of technology sales in emerging markets such as Brazil).

194 See Carlos H. de Brito Cruz \& Luiz de Mello, Boosting Innovation Performance in Brazil 5 (OECD Econ. Dep't, Working Paper No. 532, 2006) (showing that scientific and applied R\&D are highly disconnected in Brazil, and thus the country is largely incapable of converting knowledge into productivity gains for its business sector); see also ALAN Wright, INNOVATION IN BRAZIL: PUBLIC POLICIES AND BUSINESS STRATEGIES (2008) (noting that Brazilian scientists and research institutions produce knowledge in various fields yet innovation "remains largely absent in many sectors of the economy").

195 See Bird \& Cahoy, supra note 115, at 406 ("Brazil has been by far the most masterful in counteracting the economic and political influence of the United States over global intellectual property law."); see also Yu, supra note 104, at 349 (defining Brazil as the "poster child of the use of-or, more precisely, the threat to use-compulsory licenses to promote access to essential medicines").

196 See Brazil's AIDS Programme: A conflict of goals, ECONOMIST, May 12, 2007, at 42 (discussing Brazil's successful HIV/AIDS prevention and treatment program); see also Ellen't Hoen, TRIPS, Pharmaceutical Patents, and Access to Essential Medicines: A Long Way from Seattle to Doha, 3 CHI. J. INT'L L. 27, 32 (2002) (ascribing the success of Brazil's AIDS program to its ability to produce medicines domestically).

197 See Request for Consultations by Brazil, United States - US Patents Code, WT/DS224/1 (Feb. 7, 2001) (memorializing Brazil's request to analyze the United States Patent Code for consistency with obligations under the TRIPS Agreement, suggesting violations of the agreement). But see Shaffer, supra note 140, at 471 
As part of this process, Brazil issued a compulsory license over Merck's Efavirenz, an ARV, in 2007.198 The country seemingly suffered only modest sanctions costs upon its issuance of the compulsory license. To begin with, no sanctions were raised at the WTO or other international forums, as the compulsory license was largely viewed as legal under international law.199 The Special 301 Report issued by the U.S. Trade Representative criticized Brazil's discussions with patent holders, ${ }^{200}$ but the United States did not impose formal sanctions. Merck issued a press release stating that Brazil's action was an "expropriation of intellectual property" that "will have a negative impact on Brazil's reputation as an industrialized country seeking to attract inward investment, and thus its ability to build world-class research and development."201 True to Merck's claim, there are no clear signs that the pharmaceutical sector in Brazil is revamping, particularly insofar as innovation is concerned. On the other hand, there are no obvious signs of reduced FDI in Brazil. In fact, the opposite was true as of 2007: Brazil's share of FDI in 2007 totaled USD \$34.6 billion, almost twice as much as the previous year, representing one of the highest shares

("Brazil and Canada each initiated one TRIPS complaint, but these were merely symbolic claims that they filed in response to WTO complaints brought by the United States and EC against them.").

198 See Celia W. Dugger, Brazil Overrides Merck Patent on AIDS Drug, N.Y. TIMES, May 5, 2007 (noting that Brazil opted to purchase a generic version of the drug from India); Brazil Gets Abbott Discount, WALL ST. J., July 5, 2007, at B7 (discussing how Brazil came to an agreement with the pharmaceutical company Abbot on a significantly discounted price for one its drugs).

199 See, e.g., Tove Iren S. Gerhardsen, Brazil Takes Steps to Import Cheaper AIDS Drug Under Trade Law, InTELleCtuAl PROP. WATCH, May 7, 2007, http:/ /www.ipwatch.org/weblog/index.php? $p=614 \&$ res $=1280 \&$ print $=0$ ("There appears to be a general agreement that Brazil is adhering to international trade law in what it has done.").

200 See Office of the United States Trade Representative, 2007 Special 301 REPORT, 30, available at http://www.ustr.gov/sites/default/files/asset_upload _file230_11122.pdf (discussing the need for Brazil to continue attempts to engage in open dialogue with foreign pharmaceutical companies in order to reach "mutually satisfactory outcomes").

201 Richard Walker, Merck \& Co., Inc. Statement on Brazilian Government's Decision To Issue Compulsory License for STOCRINTM, AIDSPORTAL, May 4, 2007, http://www.aidsportal.org/news_details.aspx?ID=4635; R.A. Malshekar, Dir. General, Council of Sci. and Indus. Research, Speech at 10th Zuckerman Lecture (June 11, 2003). 
in the world amongst developing countries. ${ }^{202}$ In the pharmaceuticals industry specifically, FDI reached USD \$164.4 million in 2007,203 which is consistent with the historic investment levels observed in previous years. ${ }^{204}$

In fact, Brazil's aggressive bargaining behavior has manifested itself in areas where there are not specific TRIPS policies on pharmaceuticals. This may be demonstrated by three separate examples. First, Brazil remains the only developing country that has ever requested consultations pursuant to the WTO dispute settlement process with any developed country concerning the noncompliance of intellectual property laws with the TRIPS Agreement.205 Second, Brazil exercised aggressive leadership in GATT; alongside India and eight other developing countries, ${ }^{206}$ Brazil strongly opposed attempts to expand the mandate of GATT to cover substantive intellectual property issues. ${ }^{207}$ Third, Brazil vigorously led the campaign to support the free and open source software movement, noticeably alongside developed countries such as Spain and Finland. ${ }^{208}$ In fact, the open source movement's largest concentration

202 Central Bank of BraziL, InVestimento Estrangeiro Direto (2008) (on file with author).

203 Id.; CENTRAL BANK of BRAZIL, Foreign Direct InVESTMENT (2007) (on file with author).

204 Banco Central do Brasil, Distribuíção POR Atividade EconómicA DE APLICAÇÃO DOS RECURSOS (2007) (on file with author).

205 See Request for Consultations by Brazil, supra note 197 (suggesting the United States violated the agreement).

206 The other LBPs were Argentina, Cuba, Egypt, Nicaragua, Nigeria, Peru, Tanzania, and Yugoslavia. See Member States Agree to Further Examine Proposal on Development, WORLD InTEllectuAl PROP. ORG., Oct. 4, 2004, http://www .wipo.int/pressroom/en/html.jsp?file=/redocs/prdocs/en/2004/wipo_pr_2004_ 396.html (discussing a proposal by Brazil and Argentina encouraging inclusion of a development agenda in the World Intellectual Property Organization); Member States Adopt a Development Agenda for WIPO, World InTELlectuAl Prop. ORG. (Oct. 1, 2007), www.wipo.int/pressroom/en/articles/2007/article_0071.html (discussing the adoption by the World Intellectual Property Organization of a development agenda).

207 See WATAL, supra note 149, at 19 (describing Brazil as one of the "hardliner" developing countries that made a weakly supported proposal to exclude substantive intellectual property issues from the Uruguay Round of negotiations).

208 See Brian Fitzgerald \& Nic Suzor, Legal Issues for the Use of Free and Open Source Software in Government, 29 MELB. U. L. REV. 412, 422 (2005) (discussing the decision of several nations, including Brazil, to use open source products in their government offices). 
of supporting countries presently lies in South America, clearly under the leadership of Brazil. ${ }^{209}$

"Brazil has also become the first country to require any company or research institute that receives government financing to develop software to license it as open-source, meaning the underlying software code must be free to all." 210 Open source represents a small share of the global software market, but Linux and other open source solutions will find their biggest markets in developing countries, particularly in MBPs, like China and India, and HBPs in East Asia and South America. ${ }^{211}$ These countries have begun turning to open source for various reasons, including a desire not to be beholden to MNEs such as Microsoft.212 In turn, Microsoft has become a progressively harsher opponent of the open-source software model, in which the underlying code for software is freely shared for users to modify and distribute. Similarly, to the fields of pharmaceutical patents and information and communications technology ("ICT"), it upholds that the open source approach undermines innovation at large. 213

Fourth, Brazil serves as one of the leaders in the G-20 organization, which essentially congregates the twenty largest economies in the world, both from within the developed and the developing

209 See Daniel F. Olejko, Comment, Charming a Snake: Open Source Strategies for Developing Countries Disillusioned with TRIPS, 25 PENN ST. INT'L L. REV. 855, 858 (2007) (noting that Argentina, Chile, Peru, and Venezuela have also displayed a wide acceptance of open source software in "both government and industry").

210 Todd Benson, Brazil: Free Software's Biggest and Best Friend, N.Y. TIMES, March 29, 2005, http://www.nytimes.com/2005/03/29/technology/29computer .html.

211 See Free Software in Developing Countries, supra note 189 (noting that if the number of open source programmers in developing nations remains low, that "developing nations will simply remain consumers of open source products rather than participants in the larger open source market").

212 See Brazil Gives Nod to Open Source, WiRED, Nov. 16, 2003, http://www.wired.com/techbiz/it/news/2003/11/61257 (discussing how Brazilian government agencies are shifting to open source operating systems to cut costs).

213 See SANJIVA WeEraWARANA \& JivaKa WeEratunga, Open SOURCE IN DEVELOPING COUNTRIES 30 (2004), available at http://www.eldis.org/fulltext /opensource.pdf (discussing comments by Indian President Abdul Kalam supporting the use of open source software despite Microsoft's protests). 
worlds. ${ }^{214}$ Brazil's HBP-type leadership was also demonstrated in 2003 at the Cancun Ministerial during the Fifth WTO Ministerial Conference, where Brazil, together with China and India, led a coalition of twenty-one developing countries. ${ }^{215}$ Lastly, one year after the Ministerial in Cancun, Brazil was seated at the forefront of the process that led to the establishment of a development agenda within WIPO. 216

This Article thus suggests that Brazil's strategy derives from a distinct set of incentives hidden within the TRIPS Agreement. These hidden incentives render it convenient for non-innovative NICs, such as Brazil, to use compulsory licenses as part of a hardline negotiation strategy with big pharmaceutical corporations. Brazil is able to obtain net benefits from such aggressive behavior mostly because it is able to produce generics locally, something that smaller and weaker developing countries are unable to do. In turn, in a country with weak institutions and high taxation such as Brazil, the expected long-term effects of maintaining an overall weaker patent protection system in the pharmaceutical industry are less dramatic than those in more innovative countries, such as India. Brazil, unlike India, is largely a non-innovative country, particularly in pharmaceuticals. Consequently, the issuance of compulsory licenses in Brazil only modestly hinders innovation in the pharmaceutical industry over time, because such innovation tends not to occur for reasons more influential than the compulsory licenses.

214 See G-20, WHAT IS THE G-20, http://www.g20.org/about_what_is _g20.aspx (last visited Oct. 23, 2010) (providing the mandate of the G-20, along with a comprehensive membership list).

215 See Pablo A. Ormachea, Agriculture Subsidies and the Free Trade Area of the Americas, 13 LAW \& BUS. REV. AM. 139, 149 (2007) (discussing how under the leadership of Brazil, the Group of 21 was able to unify as a cohesive bargaining block).

216 See Press Release, World Intellectual Prop. Org., Member States Agree to Further Examine Proposal on Development, WIPO/PR/2004/396 (Oct. 4, 2004), available at www.wipo.int/edocs/prdocs/en/2004/wipo_pr_2004_396.html (discussing a proposal by Brazil and Argentina encouraging the inclusion of a "Development Agenda" in the WIPO); Press Release, World Intellectual Prop. Org., Member States Adopt a Development Agenda for WIPO, WIPO/PR/2007/521 (Oct. 1, 2007), available at www.wipo.int/pressroom /en/articles/2007 /article_0071.html (discussing adoption of a development agenda that included establishing a "Committee on Development and Intellectual Property" that will, amongst other things, "discuss IP and development-related issues"). 
Overall, the case of Brazil does not demonstrate that patents are uncorrelated with innovation in pharmaceuticals. Although it remains a highly controversial topic, there is some evidence of the existence of a link between patent protection and pharmaceutical innovation.217 Indeed, the lack of a more stringent enforcement of intellectual property laws may well be one of the many causes for lack of innovation in the Brazilian pharmaceutical sector. However, even supporters of stronger patent protection systems will concede that "an effective IPR regime may not be sufficient in-and-of itself to attract pharmaceutical FDI." 218 Early adherence to TRIPS has failed to cause the emergence of technological innovation in the Brazilian pharmaceutical industry. To generalize, in noninnovative NICs, TRIPS does not operate as a "carrot" for more innovation; rather, it functions as a "stick" for less piracy.

\subsubsection{Thailand/Asia}

Thailand is arguably another HBP country. The case of Thailand has a number of similarities to that of Brazil. Like Brazil, Thailand has adopted an aggressive stance on both patent bargaining and software protection. In Asia, to illustrate, some of the highest overall Free/Libre/Open Source Software ("FLOSS")related activity seems to be taking place in innovative developing countries; namely NIC countries like India, China, and Taiwan, followed by South Korea, Malaysia, Singapore, and Thailand.219

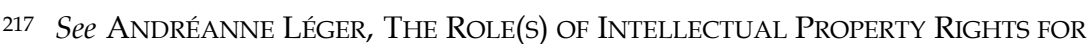
INNOVATION: A REVIEW OF THE EMPIRICAL EVIDENCE AND IMPLICATIONS FOR DEVELOPING COUNTRIES 10 (2007), available at http://www.diw.de/documents /publikationen/73/61916/dp707.pdf (stating that there is "evidence that patent protection has a strong and pervasive influence of the willingness to perform R\&D in the chemical and pharmaceutical industries"); see also Colleen Chien, Cheap Drugs at What Price to Innovation: Does the Compulsory Licensing of Pharmaceuticals Hurt Innovation?, 18 BERKELEY TECH. L.J. 853, 856 (2003) (discussing the "perception that compulsory licenses harm the incentive for innovation").

218 DOUglas Lippoldt, InTEllectual Property Rights, Pharmaceuticals AND FOREIGN DIRECT INVESTMENT 7 (2005), available at http://www.gem.sciencespo.fr/content/publications/pdf/lippoldt_IPRs_Pharma_FDI1106.pdf.

219 See Frederick Noronha, Developing Countries Gain from Free/Open-Source Software, LiNUX J., May 20, 2003, http:/ / www.linuxjournal.com/article/6884 (noting that in Asia, countries such as India, China, South Korea, and Malaysia were found to have high FLOSS-related activity while countries from the Indian subcontinent had medium-level activity). 
Moreover, Thailand has been one of the few developing countries to actually carry out compulsory licenses of drugs. It did so for the first time in 2006, with the compulsory license of Merck's Efavirenz, the same drug on which Brazil imposed a compulsory license. ${ }^{220}$ Only a few months later, Thailand issued two more compulsory licenses, one for Abbott's Kaletra, an AIDS drug, and another for Sanofi-Aventis' Plavix, a heart medicine.221 The compulsory license over Plavix represents a particularly clear expression of high bargaining power on the part of Thailand, given that whether a heart disease drug meets the TRIPS criterion of "national emergence" is questionable as a matter of law.222 Such a compulsory license could have potentially given rise to Tier-1 sanctions authorized by the WTO which in fact never happened-but the Thai government acted irrespective of that risk.

The dynamics of Tier-2 sanctions in Thailand are similar to those seemingly prevailing in Brazil. First, Thailand is actually in a

220 See Letter from Dr. Thawat Suntrajarn, Dir. Gen., Dep't of Disease Control, to Manager, Merck Sharp \& Dohme Corp. (Nov. 29, 2006), reprinted in FACTS AND EVIDENCES ON THE 10 BURNING ISSUES RELATED TO THE GOVERNMENT USE OF PATENTS ON Three Patented Essential Drugs in Thailand 47-48 (Vichai Chokevivat ed., 2007), available at http://www.moph.go.th/hot/White\%20Paper\%20CL-EN.pdf (stating the Ministry of Public Health decided to use it patent rights to increase the accessibility of Merck's Efavirenz "for public interests").

221 See Decree of Dep't of Disease Control, Ministry of Pub. Health, Regarding Exploitation of Patent on Drugs \& Medical Supplies by the Government on Combination Drug Between Lopinavir \& Ritonavir (Jan. 29, 2007), http://www.cptech.org/ip/health/c/thailand/thai-cl-kaletra_en.pdf (invoking rights under the Thai Patent Act to permit compulsive licensing of Kaletra); Announcement, Ministry of Pub. Health, Regarding Exploitation of Drugs and Medical Supplies for Clopidogrel (Jan. 25, 2007), http://www.cptech.org /ip/health/c/thailand/thai-cl-clopidogrel_en.pdf (notifying the public of intent to permit compulsive licensing of Plavix).

222 See, e.g., Editorial, Bangkok's Drug War Goes Global, WALL ST. J. EuR., Mar. 7, 2007, at 11 (arguing that Thailand is "exploiting vague language" in the TRIPS Agreement to issue compulsory licenses for a non-existent national emergency); Ronald A. Cass, Thai Patent Turmoil, WALL ST J. AsIA, Mar. 13, 2007, at 13 (arguing that "Thailand's assertion of a right under TRIPs to impose compulsory licensing rests on shaky ground"); Tove Iren S. Gerhardsen, Drug Company Reacts to Thai License; Government Ready to Talk, InTELlectuAl Prop. WATCH (Feb. 16, 2007), http:/ / www.ip-watch.org/weblog/index.php?p=538\&res $=1280 \&$ print $=0$ (reporting that Sanofi-Aventis was surprised by the mandatory licensing of Plavix since the drug arguably did not treat a health concern that justified a compulsory license). 
position to obtain net benefits with the issuance of compulsory licenses; mainly because it possesses an established manufacturing capability in pharmaceuticals. ${ }^{223}$ In fact, a state-run capacity to produce generics, particularly AIDS drugs, further enhances the ability of the country to pose a veritable threat of issuing compulsory licenses.224 Second, Tier-2 sanctions costs play out in Thailand in a similar fashion to that of Brazil. Like Brazil, the pharmaceutical industry in Thailand is relatively small in comparison to other sectors of the local economy. Moreover, the Thai pharmaceutical industry is mostly geared towards supplying the local market, rather than manufacturing for export. In addition, the industry does not involve research and development of new drugs and components. ${ }^{225}$ Over the coming years, "Thailand will likely remain an overall importer of medicines, with the trade balance further shifting in favor of imports . ..."226 Moreover, and although Abbott Laboratories recently withdrew seven registration applications for newly-developed pharmaceutical products in Thailand, the Thai government seemingly relies on the expectation that its markets are large enough to sustain sufficiently interested MNEs.227 Tier-1

223 See Rein, supra note 111, at 402 (noting that Thailand has reduced drug prices by actively producing generic drugs and by "limited protection of exclusive marketing rights").

224 See Sanchai Chasombat et al., The National Access to Antiretroviral Program for PHA (NAPHA) in Thailand, 37 Southeast Asian J. Tropical Med. \& Pub. HEALTH 704, 706 (2006) (explaining how Thailand's National Access to Antiretroviral Program for People living with HIV/AIDS ("NAPHA") increased patient access to affordable drugs).

225 See Ames Gross, New Regulatory Trends In Thailand's PhARMACEUTICAL MARKET (1999), available at http://www.pacificbridgemedical .com/publications/html/ThailandMar1999.htm (stating that Thailand's pharmaceutical industry involves little research and design and that it imports most of the ingredients used to make pharmaceutical drugs).

226 Press Release, Research and Mkts., In Thailand's Pharmaceutical Market Generics Are Likely to Be the Fastest-Growing Segment, Reaching US\$1.63bn in 2010 from US\$1.1bn in 2005, (May 1, 2007), available at http://findarticles.com/p /articles/mi_m0EIN/is_2007_May_1/ai_n27219824.

227 See Press Release, Médecins sans Frontières, MSF Denounces Abbott's Move to Withhold Medicines from People in Thailand (Mar. 15, 2007), available at http:/ / www.msf.org/msfinternational/invoke.cfm?objectid=55646135-15C5F00A-25D3DAC13D288586\&component=toolkit.pressrelease\&method=full_html (discussing Abbotts Laboratories' "decision not to market its new medicines in Thailand"); see also Nicholas Zamiska, Abbott's Thai Pact May Augur Pricing Shift, WALl ST. J., Apr. 23, 2007, at A3 (noting that while Abbott Laboratories began sell- 
sanctions costs appear to play out favorably for Thailand as well. In recent negotiations with the United States, Thailand notably rejected a proposed FTA. ${ }^{228}$ This FTA would have, among other things, required a greater commitment by the Thai government to enhance patent protection. This rejection again represents a typical HBP bargaining stance, paralleling that of Brazil. After all, Brazil thus far has not agreed to the framework laid out by the United States for the intended Free Trade Area of the Americas ("FTAA"), which contains similar TRIPS-plus provisions. ${ }^{229}$

To conclude, the similarities between the cases of Thailand and Brazil are abundant. In spite of sharp differences in their political systems, 230 to date the only developing countries that have

ing the AIDS drug Kaletra in Thailand, it still refused to sell six other types of drugs to Thailand); Henry J. Kaiser Family Foundation, Abbott To Stop Launching New Drugs in Thailand in Response to Country's Compulsory License for Antiretroviral Kaletra, KAISER DAILY HIV/AIDS REPORT (Mar. 14, 2007), http://www .kaisernetwork.org/daily_reports/rep_index.cfm?hint=1\&DR_ID $=43558$ (noting that Abbott Laboratories had announced plans to withdraw seven drug applications from Thailand in response to Thailand's issuance of a compulsory license for the AIDS drug Kaletra).

228 See, e.g., Sanya Smith, Thai Human Rights Commission Criticizes FTA with US, THIRD WORLD NETWORK, Jan. 26, 2007, http://www.twnside.org.sg/title2 /twninfo492.htm (reporting that the National Human Rights Commission of Thailand issued a draft report concluding that the proposed free trade agreement between Thailand and the United States would "violate the human rights of the Thai people and affect the country's sovereignty").

229 See Human Rights Watch - HIV/AIDS Program, Comment on the Draft Text of the Agreement on the Free Trade Area of the Americas (2003), available at http://www.cptech.org/ip/ftaa/hrw02272003.html (noting that these provisions "pose a significant danger to developing countries facing public health emergencies"); Ormachea, supra note 215, at 145-46 (noting Brazil's "unwillingness to acquiesce to American interests in the context of FTAA negotiations"). See generally Angelina Yearick Heimel, The Power of a Patent: The Impact of Intellectual Property Protections in the Free Trade Area of the Americas Agreement on the Plight of Prescription Drug Availability and Affordability in Central and South America, 16 PACE INT'L L. REV. 447, 467 (2004).

230 Thailand's compulsory licenses were issued by a military government; Brazil's compulsory licenses were issued by a democratic government. See generally Roger Bate, Thailand and the Drug Patent Wars, AM. ENTERPRISE Inst HeAlth POL'Y, Apr. 2007, available at http://www.aei.org/outlook/25890 (stating that one of Thailand's military government's goals is to strengthen domestic drug manufacturing, one of its strongest areas); Medical News Today, supra note 201 (discussing the Brazilian President's issuance of a compulsory license to produce a generic version of Efavirenz). 
achieved universal access to ARV therapy to AIDS patients have been Brazil and Thailand. ${ }^{231}$ In both cases, more ambitious health programs were made possible by aggressive price negotiations with big pharmaceutical companies, among other things. This strategy, in turn, was largely premised on the issuance-or more commonly, the real threat of issuance-of compulsory licenses over patented drugs. ${ }^{232}$ The ensuing paradox, to insist on this term, lies also in that overall less powerful countries such as Brazil and Thailand are proving more successful in dealing with the AIDS epidemic than other countries that are more powerful overall, such as India and China. ${ }^{233}$ This situation arises in countries such as Brazil and Thailand not in spite of their lack of pharmaceutical innovation, but in part because of it.

\subsubsection{South Africa/Africa}

A third HBP to practice aggressive bargaining is South Africa. The country boasts the largest economy in the African continent, and enjoys noticeable political influence over other African countries. In relative terms, it is expected to remain quite powerful vis-

231 See World Health ORG. \& UNAIDS, Progress On Global Access to HIV ANTIRETROVIRAL THERAPY: A REPORT ON “3 BY 5” AND BEYOND 36 (2006) (noting that Brazil and Thailand's efforts have led to low mother-to-child transmission rates); Nathan Ford et al., Sustaining Access to Antiretroviral Therapy in the LessDeveloped World: Lessons from Brazil and Thailand, 21 AIDS S21, S21 (2007) (noting that Thailand and Brazil "are among the few developing countries that can be said to have achieved universal access to antiretroviral therapy").

232 See Cheri Grace, The EfFect of Changing Intellectual Property on Pharmaceutical Industry Prospects in India AND CHINA: Considerations FOR ACCESS TO MEDICINE 15 (2004) (noting that a country's threat to issue a compulsory license compels many patent originators to lower their prices).

233 See HIV and AIDS in Brazil, AVERT, http:/ / www.avert.org/aids-brazil.htm (last visited Oct. 23, 2010) (describing Brazil's response to HIV and AIDS as a "success story"); HIV and AIDS in China, AVERT, http://www.avert.org /aidschina.htm (last visited Oct. 23, 2010) (noting that China recently discovered the "danger of ignoring HIV and AIDS" and has implemented a program to combat the epidemic); HIV and AIDS in India, AVERT, http://www.avert.org /aidsindia.htm (last visited Oct. 23, 2010) (discussing the difficulties in combating $\mathrm{HIV} / \mathrm{AIDS}$ in India due to its high levels of illiteracy, poverty and citizens suffering from poor health); HIV and AIDS in Thailand, AVERT, http://www.avert.org /aidsthai.htm (last visited Oct. 23, 2010) (noting that Thailand is one of the very few developing countries in the world "where public policy has been effective in preventing the spread of HIV and AIDS on a national scale"). 
à-vis other developing countries. ${ }^{234}$ Similar to Brazil and Thailand, South Africa is engaged in little to no innovation on the ground, particularly in pharmaceuticals. In that sense, it may be more narrowly classified as a non-innovative NIC.

There are three persuasive indications of South Africa's HBPlike bargaining situation. First, alongside Brazil, South Africa was prominently involved in the negotiations ${ }^{235}$ that led to the Decision on the Implementation of Paragraph 6 of the Doha Declaration on the TRIPS Agreement and Public Health. ${ }^{236}$ In retrospect, there is wide consensus that South Africa made an important contribution to what is sometimes regarded as a turning point in the TRIPS debate. ${ }^{237}$ Second, the country has been noticeably influential in placing the issue of access to medicines on the human rights and public health agendas. ${ }^{238}$

Third, South Africa withstood great pressure from the United States in the process of amending its intellectual property law. In 1997, South Africa passed the Medicines Amendment Act, ${ }^{239}$ allow-

234 See Jim O'Neill et al., Global Economics Paper No.134: How Solid Are the BRICs?, GOLDMAN SACHS ECON. RES., Dec. 2005, at 1, 19 app.3, available at http://www2.goldmansachs.com/ideas/brics/how-solid-doc.pdf (noting that, like the BRICs, South Africa is ranked 43, placing in the top half of the growth environment rankings for developing countries).

235 See Sonia E. Rolland, Developing Country Coalitions at the WTO: In Search of Legal Support, 48 HARV. INT'L L.J. 483, 496 (2007) (listing Brazil, India, and Pakistan as the three developing countries most "prominently involved" in negotiations).

236 Decision of the General Council, Implementation of Paragraph 6 of the Doha Declaration on the TRIPS Agreement and Public Health, WT/L/540 (Aug. 30, 2003).

237 See, e.g., Ruth Mayne, The Global Campaign on Patents and Access to Medicines: An Oxfam Perspective, in GlobAl InTEllectuAl Property Rights: KNowledGe, AcCess AND Development 244, 249 (Peter Drahos \& Ruth Mayne eds., 2002) (noting that South Africa's decision to fight a lawsuit against its 1997 Medicine Act "was a critical factor in generating global media interest"); SUSAN K. Sell, Private PoWer, Public LaW: The Globalization of INTELlectual Property RIGHTS 146, 181 (2003) (stating that the "HIV/ AIDS pandemic . . . sped up the revelation of the negative consequences of TRIPS").

238 See Philippe Cullet, The Doha Declaration of the WTO and Access to Medicines (Int'1 Envtl. Law Research Ctr., Briefing Paper No. 2002-1, 2002), available at http://www.ielrc.org/content/f0201.htm (discussing the legal consequences of South Africa's attempt to "foster public health goals").

239 Medicines and Related Substances Control Amendment Act 90 of 1997 (S. Afr.). 
ing for parallel imports of pharmaceuticals. ${ }^{240}$ Controversy erupted over this legislation, and the United States government threatened sanctions if the South African government put the Medicines Amendment Act into full force. ${ }^{241}$ The United States Congress included in its appropriations bill in 1998 a provision withholding aid monies for South Africa until the Medicines AmendAmendment Act was repealed.242 The Clinton administration eventually backed away from its original stance, even though it was heavily lobbied by the pharmaceutical industry-the latter having reduced Tier-2-like sanction power vis-à-vis its HBP bargaining counterpart. Unsurprisingly, South Africa did not back down.243 The United States government later withdrew its legislation after the South African government asserted that it was legally able to utilize parallel imports and compulsory licenses under TRIPS. On the South African side, the only compromise made was to repeat earlier promises that South Africa would abide by the WTO's TRIPS Agreement. ${ }^{244}$

240 See Mary Beth Walker, Assessing the Barriers to Universal Antiretroviral Treatment Access for HIV/AIDS in South Africa, 15 DUKE J. COMP. \& INT'L L. 193, 210 (2004) (outlining the provisions of domestic law that were added to the $1965 \mathrm{Me}-$ dicines and Related Substances Control Act; effectively allowing parallel importing).

241 Id. at 211.

242 See generally Agriculture, Rural Development, Food and Drug Administration and Related Agencies Appropriations Act, Pub. L. No. 105-277, 112 Stat. 2681155 (1999) (expressly prohibiting the use of appropriated funds until the United States Government took steps to "work with the Government of the Republic of South Africa to negotiate the repeal, suspension, or termination of section 15(c) of South Africa's Medicines and Related Substances Control Amendment Act No. 90 of $1997 . . . . "$ )

243 See Hoen, supra note 196, at 31 (discussing the international public outrage over the U.S. drug companies' legal challenge of the medicine laws in developing countries and the ensuing public pressure that resulted in the companies deciding to drop the case).

244 See JAmes LOVE, Five COMMON Mistakes by Reporters COVERING US/SOUTH AFRICA DisPUTES OVER COMPULSORY LICENSING AND PARALLEL IMPORTS, http://www.cptech.org/ip/health/sa/mistakes.html (last visited Oct. 23, 2010) (arguing that South Africa did not "back down" and listing the promise to abide by the TRIPS Agreement as its one and only concession); EUROPEAN COMMISSION, DIFFERENT NEEDS, DIFFERENT RESPONSIBILITIES: WHAT IS THE EU ASKING FROM DEVELOPING COUNTRIES?, http://trade.ec.europa.eu/doclib/docs/2005/december /tradoc_126493.pdf (last visited Oct. 23, 2010) (stating that "advanced developing countries" include "the large emerging economies of the G20, who combine de- 
To conclude, the explanation for HBPs' unique bargaining situation is threefold. First, and most notable, HBPs stimulate a collapse of the Tier-2 sanction costs. This statement is true with respect to MNEs, and at times local investors, both of which refrain from conducting R\&D locally, even in the face of strong patent laws. Furthermore, HBPs possess large consumer markets that tend to be highly desirable to large MNEs. As can be expected, early adherence to TRIPS strict patent policies has failed to cause the emergence of research and development in innovation in the pharmaceutical industry in HBPs. Lack of innovation in 'noninnovative NICs' has transformed economically weaker NICs into stronger bargaining powers in patent-sensitive products such as pharmaceuticals. Such is the case when countries threaten to issue, or actually issue, patent compulsory licenses. Second, the shortage of local innovation frees HBP governments, such as Brazil, Thailand, or South Africa, from pressures of a local industry that requires more stringent patent protection. This economic-political reality facilitates, rather than harms, HBPs' power to issue compulsory licenses over pharmaceuticals. Third, and more generally, in HBP countries, TRIPS does not effectively function as a "carrot" for more FDI or innovation, rather, it serves a "stick" to exert pressure in favor of Pax-American tailor-made intellectual property rights.

\subsection{The MBP Model: A Dual-Sanction Cost Structure}

\subsubsection{Introduction}

Among NICs, innovative countries are those that benefit the least from bargaining around TRIPS through compulsory licenses or threats thereof. Simply put, the main reason for this phenomenon is that in these countries compulsory licenses discourage local innovation. These countries paradoxically possess a weaker bargaining position in terms of their ability to issue compulsory licenses, mainly because MBPs are subject to a "dual sanctions" cost structure. First, on a Tier-1 bargaining level, a compulsory license can cause the United States government to impose sanctions. While strong in comparison to the rest of the developing world, MBPs remain dependent on strengthening their commercial ties

veloping country status with high competitiveness in one or more export sector, such as Brazil (Agriculture), China (Manufacturing) and India (Services)"). 
with the developed world. Second, on a Tier-2 bargaining level, MBPs' markets may be sanctioned, by either MNEs or national investors, particularly insofar as the issuance of compulsory licenses for pharmaceuticals may harm the MBPs' innovation incentives. The Tier-2 sanction costs are also ever-present with the bio agriculture and plant genetics patent-sensitive industries. Developed countries' support for extreme biotechnology measures that threaten to supplant the conventional intellectual property regime and to undermine food security in the underdeveloped world is expressed in manipulative genetic use restriction technologies ("GURTs"). They are also jointly known as Terminator Technology.245 These technologies are a genetic engineering method that limits genetic copy propagation by producing sterile seeds unfit for subsequent planting. ${ }^{246}$ Similar to Digital Rights Management ("DRM") software technologies, it is a form of self-enforcing patents devoid of experimental use doctrines within patent law. ${ }^{247}$ The United States, Canada, Australia, New Zealand and noticeably Argentinean MNEs, are all active supporters of terminator technologies, and have continued to press for commercial exploitation of GURTs. ${ }^{248}$

245 See, e.g., C. S. Srinivasan \& Colin Thirtle, Impact of Terminator Technologies, in Developing Countries: A Framework for Economic Analysis, in ECONOMIC AND SOCIAL ISSUES IN AgRicUltural BioteCHNOlOGy 159, 161 (R.E. Evenson et al. eds., 2002) (arguing that terminator technology is a remedy to intellectual property infringement); John Vidal, World Braced for Terminator 2, GUARDIAN., Oct. 6, 1999, at 14, available at http://www.guardian.co.uk/science/1999/oct/06/gm.food2 (describing the tension between developing countries and Monsanto due to the terminator technology).

246 See Vidal, supra note 245 (explaining that in Monsanto's version of the terminator technology, the seeds are soaked in tetracycline, which "ultimately instructs the plant to kill its own seeds").

247 See Convention on Biological Diversity, Subsidiary Body on Scientific , Technical and Technological Advice, Rep. of the Ad Hoc Technical Expert Group Meeting on the Potential Impacts of Genetic Use Restriction Technologies on Smallholder Farmers, Indigenous and Local Communities and Farmers' Rights, 9th mtg., Nov. 10-14, 2003, U.N. Doc. UNEP/CBD/SBSTTA/9/INF/6 (Sept. 29, 2003) [hereinafter Convention on Biological Diversity] (discussing the potentially negative effects of Genetic Use Restriction Technologies).

248 See Press Release, Rural Advancement Found. Int'1 Biodiversity Convention's Terminator Decision Fails Biodiversity and Fails Farmers (June 28, 1999), available at http://www.cbd.int/doc/meetings/sbstta/sbstta-09/information /sbstta-09-inf-06-en.pdf (reiterating the United States' position that GURTs are 
With software in the United States, major MNEs align to lobby the government to enforce their interests under the umbrella of the International Intellectual Property Alliance ("IIPA"). ${ }^{249}$ The IIPA collects information about intellectual property piracy overseas and regularly reports it to the USTR.250 Overall, if the development economics history of developed countries should repeat itself, these MBPs eventually will want stronger intellectual property protection as an important means of transforming into fully developed countries. Having demonstrated significant promise in carrying out health innovation in particular, ${ }^{251}$ China and India are most likely to be the first to reach a point at which creating stronger patent protection will be in their pure self-interest. 252

more good than bad. This raised serious concerns by the CBD and a majority of the international community); see also Convention on Biological Diversity supra note 247 (listing potential positive impacts of GURTs, such as increased agricultural biodiversity and the reduction of problems with volunteer plants). Within the realm of bio-agriculture alone, LBP Argentina should therefore exceptionally be considered as an MBP. Id.

249 See DESCRIPTION OF THE IIPA, http://www.iipa.com/aboutiipa.html (last visited Oct. 23, 2010) (explaining the role the Alliance plays in the private sector and providing examples of the Alliance's work.).

250 See id. (providing examples of instances where the IIPA submitted reports to the USTR). See generally MEMBER ASSOCIATIONS, http://www.iipa.com /memberassociations.html (last visited Oct. 23, 2010) (listing members of other alliances of industry specific groups such as: the Association of American Publishers ("AAP"), the Business Software Alliance ("BSA"), the Entertainment Software Association ("ESA"), the Independent Film \& Television Alliance ("IFTA"), the Motion Picture Association of America ("MPAA"), the National Music Publishers' Association ("NMPA"), and the Recording Industry Association of America ("RIAA")).

251 See Mashelkar, supra note 201, at 4 fig.1 (showing the relationship between a country's economic strength and its innovative capability); Morel et al., supra note 182, at 2 (noting that developing countries have the "capacity to develop, manufacture, ensure safety, and market new health products").

252 See Yu, supra note 104, at 391 (stating that this is not surprising given that China and India were the "two largest economies in the world before the Industrial Revolution"). See generally, CHINDIA: How CHINA AND INDIA ARE REVOLUTIONIZING GLOBAL Business (Pete Engardio ed., 2007) (discussing the rise of "Chindia," examining differences between the two countries in terms of market power and social and business culture, and reflecting on the problems that lie ahead); id. at 4-7 (exploring China's strength in the manufacturing industry and India's strength in its software and design industries); ROBYN MEREDITH, THE ELEPHANT AND THE DRAGON: THE RISE OF INDIA AND CHINA AND WHAT IT MEANS FOR ALL OF Us 63 (2007) (using the Philips case to exemplify the latitude that China has 


\subsubsection{India}

A number of fundamental advantages position India as the more promising incubator for pharmaceutical innovation within the developing world. ${ }^{253}$ With its "burgeoning science and technology sector, skilled workforce, [and a] democratic government . . . India presents a uniquely situated laboratory for advanced developing country patent systems." 254 Current academic work on the role of intellectual property law in advanced developing economies stills focuses more on China than on India. ${ }^{255}$ India however

taken in using intellectual property to grow while not paying for the use of those rights); JAIRAM RAMESH, MAKING SENSE OF CHINDIA: REFleCtIONS ON CHINA AND INDIA (2006) (presenting thoughts on the relationship between China and India through a comparison of the two countries in the contexts of trade, investment, international relations, and public health); Shubham Chaudhuri \& Martin Ravallion, Partially Awakened Giants: Uneven Growth in China and India, in DANCING WITH Giants: ChinA, INDIA, AND THE Global ECONOMY 175 (L. Alan Winters \& Shahid Yusuf eds., 2007) (examining the impact that uneven economic growth will likely have on the rate of poverty reduction in India and China); Daniel C.K. Chow, Why China Does Not Take Commercial Piracy Seriously, 32 OHIO N.U. L. REV. 203, 208 (2006) (proffering China's ambitions "to eventually dominate trade in hightechnology sectors"); Dominic Wilson \& Roopa Purushothaman, Global Economics Paper No. 99: Dreaming with BRICs: The Path to 2050, GOLDMAN SACHS ECON. RES., Oct. 2003, at 4, available at http://www2.goldmansachs.com/ideas/brics/book /99-dreaming.pdf ("China could overtake Germany in the next four years, Japan by 2015 and the US by 2039.").

253 See Nicholas D. Kristof, They're Rounding the First Turn! And the Favorite Is . . ., N.Y. TIMES, Jan. 17, 2006, at A19 (predicting that India's development will outpace China's due to India's stable financial and political infrastructure).

254 Janice M. Mueller, The Tiger Awakens: The Tumultuous Transformation of India's Patent System and the Rise of Indian Pharmaceutical Innovation, 68 U. PITT. L. REV. 491, 503 (2007) (footnote omitted).

255 See, e.g., Yu, supra note 104, at 391 (discussing the growth and development of the Chinese economy and predicting that the country will eventually "move into the world's high-end market"); see also Jeffrey A. Andrews, Pfizer's Viagra Patent and the Promise of Patent Protection in China, 28 LoY. L.A. INT'L \& COMP. L. REV. 1 (2006) (proposing that recent cases demonstrate a growing acceptance of patent protection in China, although the concerns over infringement continue to be real and substantial); Ke Shao, Look at My Sign! - Trademarks in China from Antiquity to the Early Modern Times, 87 J. PAT. \& TRADEMARK OfF. SOC'Y 654 (2005) (exploring the evolution of trademark use in China); Robert Slate, Judicial Copyright Enforcement in China: Shaping World Opinion on TRIPS Compliance, 31 N.C. J. INT'L L. \& COM. REG. 665 (2006) (analyzing the internet methods employed by the Chief Justice on the Intellectual Property Tribunal in China to influence public opinion on China's compliance with TRIPS); Straus, Bargaining Around 
falls similarly within the category of innovative NICs, and is therefore an MBP as well.

The Indian pharmaceutical industry developed in a context of weak patent protection with the Indian Patent Act of 1970 denying product patent coverage altogether for pharmaceutical products and severely limiting process patents. ${ }^{256}$ The Indian industry focused mainly on reverse engineering and the production of generics, ${ }^{257}$ while it spent little on R\&D in comparison with firms in Western countries. ${ }^{258}$ The generics industry that flourished in India allowed the country to gain its current rank as fourth globally in terms of medicine production (eight per cent of global output volume) and thirteenth in terms of value. ${ }^{259}$ India also boasts the largest number of manufacturing facilities approved by the U.S. Food and Drug Administration anywhere outside of the United

TRIPS, supra note 10 (examining the fragile balance between the protection of intellectual property rights in China and international trade with other nations); $\mathrm{Yu}$, supra note 124 (providing an overview of Chinese response to American intellectual property policy; in particular, the actions taken by the Chinese government pursuant to the 1992 Memorandum of Understanding Between China and the United States on the Protection of Intellectual Property).

256 See SAMPATH, supra note 129, at 24 (noting that process patents were limited to the shorter of a period of seven years, or five years from the date of sealing of the patent). Moreover, the provisions on "local working" and licensing of rights further limited the scope of process patents by providing that:

[A]ny pharmaceutical process on which a local patent was obtained had to be "worked" in India within three years from the date of sealing of the patent. After three years of sealing, the patent owner was subject to the provision on "licensing of rights," i.e., the patent owner was obliged to license his process to a local manufacturer in cases where the patent was not locally worked for a royalty not exceeding $4 \%$. The government also had the authority to grant a compulsory license on a process after three years from the date of sealing of the patent if the product was not available locally at "reasonable" rates.

Id.

257 See V. C. Vivekanandan, HRD Intellectual Prop. Chair Professor, Nalsar Univ. of Law, Post TRIP: Emerging issues for Pharma Industry (July 11, 2008), available at http://pharmexcil.com/data/uploads/Prof.Vivekanandan.ppt (noting that Indian pharmaceutical companies currently produce around $20-22 \%$ of the world's generic drugs).

258 See Sampath, supra note 129 , at 31.

259 Mashelkar, supra note 201, at 7; Morel, supra note 182; Vivekanandan, supra note 257. 
States. ${ }^{260}$ With this increase in production, part of the Indian pharmaceutical industry started a slow but steady shift toward developing a capacity to innovate. ${ }^{261}$

Major strengths of the Indian pharmaceutical market power include a cost-competitive manufacturing base that extends to clinical studies, and extensive production skills in chemistry and process development. The market also possesses the ability to manufacture over $50 \%$ of the bulk drugs needed for its pharmaceutical production activities locally. There has also been an emergence of a promising biotechnology industry. In addition, India is known for its plethora of local scientists and high quality R\&D personnel and a wide network of R\&D. ${ }^{262}$ While the R\&D expenditures of large-scale Indian pharmaceutical firms $(1.9 \%$ of total revenues) is still relatively low in comparison with those of global pharmaceutical industries, the expenditures have been steadily growing at the rate of $18 \%$ per year. ${ }^{263}$

India is also at the crossroads concerning its intellectual property policies for the biotechnology sector. For a start, it has ambitious plans for a biotechnology industry and for its agricultural industry. Presently it has the third-highest number of biotech companies in the Asia-Pacific after Japan and Korea. ${ }^{264}$ Conversely, India witnesses an internal persistent disagreement to a strengthening of the patent system related to biotechnological inven-

260 See Jaya Prakash Pradhan, Overcoming Innovation Limits through Outward FDI: The Overseas Acquisition Strategy of Indian Pharmaceutical Firms, INSTITUTE FOR THE StUdy OF InDUSTRIAl DeVElopment, July 2008, available at MPRA, Paper No. 12362, http://mpra.ub.uni-muenchen.de/12362/1/MPRA_paper_12362.pdf (detailing the acquisition strategies of five Indian pharmaceutical companies which engaged in an aggressive plan to acquire new products and technology).

261 See Mashelkar, supra note 201 (describing India's push to innovate).

262 See Cheri Grace, The Effect of Changing Intellectual Property on Pharmaceutical Industry Prospects in India and China: Considerations for Access to Medicines 18 (DFID-Health Systems Resource Centre, 2004) (describing the core competencies and cost advantages of Indian pharmaceutical companies).

263 See SAMPATH, supra note 129, at 31 (noting that Indian pharmaceutical companies have steadily increased research and development spending); See also Vivekanandan, supra note 257 (analyzing the effect of the TRIPS Agreement on the pharmaceutical industry in India).

264 Christoph Antons, Sui Generis Protection for Plant Varieties and Traditional Agricultural Knowledge: The Example of India, 29 EUR. INTELL. PROP. REV. 480, 480 (2007). 
tions. ${ }^{265}$ While India is only slowly and unwillingly opening the door to allow for a greater role of patents related to biotechnological inventions, it has been positive in the development of fairly unique plant variety legislation in the form of its the Protection of Plant Varieties and Farmers' Rights Act of 2001 ("PPVFRA"). ${ }^{266}$ Lastly, within the software patent-sensitive industry, India further stands for an archetypical Tier-2 sanction costs fearful MBP. Recent studies show that India has experience "rampant software piracy, because of high Tier-2 sanction costs." 267 In its 2005 Piracy Study, the Business Software Alliance ("BSA") notes: "India, whose IT exports are more than triple the size of its domestic IT market, still has a piracy rate of $74 \%$ - despite the strength of its world-class software development skills and government efforts to quell piracy." 268 This reality, stands as a central inhibitor to the growth of a local Indian packaged software industry.

\subsubsection{China}

China is already the second largest producer of pharmaceutical and agricultural products in the world. ${ }^{269}$ It is the world's largest producer of active pharmaceutical ingredients, 270 although the vast majority of this production is unpatented. In fact, China is one of

265 See id. (describing the struggle patentees face in India with respect to securing patent rights).

266 Id. at 482.

267 Kopczynski, supra note 171, at 299-329 (citing Press Release, Business Software Alliance, New BSA Study Shows That India's Dynamic IT Sector Could Nearly Triple by 2009 (Dec. 8, 2005), available at http://www.bsa.org / country/News\%20and\%20Events/News\%20Archives/en/2005en-12082005-

globalpiracystudy.aspx) (proposing a forecast that shows how India's economic growth will be fueled by cutting down on global piracy). But see BMC Software to Invest \$12 $\mathrm{M}$ in India, CYBER INDIA ONLINE LIMITED, (May 20, 2005), available at http://web.archive.org/web/20050525225729/http://www.ciol.com/content/ne ws/Investment/2005/105052001.asp (last visited Oct. 20, 2010) (reporting BMC's plan to expand in India, investing in research and development and employing 1,500 Indian workers); Intel Plans \$1bn India Investment, BBC NEWS (Dec. 5, 2005), available at http://news.bbc.co.uk/2/hi/business /4499362.stm (describing Intel's plan to expand its business in India).

268 Bus. SofTwARE Alliance \& INT'L DATA CORP., SECOND ANNUAL BSA AND IDC GLOBAL SOFTWARE PIRACY STUDY 3 (2005).

269 See Grace, supra note 262, at 13 (stating China is the largest producer in the world of penicillin, vitamin $\mathrm{C}$, terramycin, doxycycline and cephalosporin,).

$270 \mathrm{Yu}$, supra note 104, at 363. 
the world's leaders in the production of counterfeit pharmaceuticals. ${ }^{271}$ Given that MBP countries herein have also been referred to as 'innovative NICs,' the case of China requires further exploration.

The characterization of China as an MBP is essentially because it faces large Tier-2 sanctions costs for the issuance of compulsory licenses, and for two additional reasons. The first reason is China is undergoing a somewhat uncertain, yet steady, process toward becoming an ever more innovative country. ${ }^{272}$ The days in which China only produced cheap products of low quality are rapidly being left behind. To begin with, "[f]or the past three years China has also been the world's largest exporter of [ICT]." 273 Consequently,

[t]ensions have developed between China and the United States regarding trade and standards. One point of contention concerns, on the one hand, China's approach to standard setting, particularly for ICT goods, and on the other, the role of IP rights in international standard setting. While the ICT industry increasingly demands harmonized standards to serve the imperatives of competition, interoperability, and efficiency, particularly in networked environments, China has signaled its intention to follow a different direction. By seeking to set its own domestic standards instead of relying on international standards, China not only creates tensions but also raises trade law issues under WTO rules. 274

271 See Maria Nelson et al., Counterfeit Pharmaceuticals: A Worldwide Problem, 96 TRADEMARK REP. 1068, 1089 (2006) (noting that China remains one of the world's largest sources of counterfeit pharmaceuticals).

272 See Fang Xin, Member of Standing Committee, NPC, China, From Imitation to Innovation: A Strategic Adjustment in China's S\&T Development, Seminar on Latin American, Caribbean, and Asian Strategies for Science, Technology, and Competitiveness (Apr. 7, 2005) (powerpoint presented at the Seminar on Latin American, Caribbean, and Asian Strategies for Science, Technology, and Competitiveness), http://info.worldbank.org/etools/docs/library/152771/Dr_Fang.pdf (discussing problems and solutions to China's developing national innovation system).

273 Technology in Emerging Economies, ECONOMIST, Feb. 9, 2008, at 75.

274 Gibson, supra note 40, at 1421. 
Moreover, China possesses an innovative agriculture industry. This is due to fact that the U.S. Department of Agriculture ("USDA") and China's Ministry of Science and Technology ("MOST") renewed a 2002 protocol that supports the United States' policy to establish and expand science and technology exchanges with China to improve market access for agricultural products. 275 In sum, there is now clear evidence that research and development activities in the Chinese economy have been growing steadily over the past decade within these fields. ${ }^{276}$

Lastly, in reference to this Article's focal point, in pharmaceuticals, an increase in the number of patents being filed locally is evidence the country is gearing its economy toward becoming increasingly innovative. To be sure, the overall annual research and development expenditures of Chinese pharmaceutical firms in 2002 were still relatively low--corresponding to only $1.18 \%$ of turnover. This number, however, should not obscure the broader trend showing that research and development investments in pharmaceuticals have increased five-fold in the period between 1995 and 2004. ${ }^{277}$ In a patent-sensitive industry such as pharmaceuticals, the issuance of compulsory licenses would be expected to negatively affect such a trend.

Second, the perception about the levels of patent protection in pharmaceuticals crosses over to other industries. The decision to invest in R\&D in any sector is partly based on the perception by

275 See Press Release, U.S. Dep't of Commerce, The U.S.-China Government Signing Ceremony Fact Sheet 1 (Dec. 11, 2007), available at http://20012009.commerce.gov/NewsRoom/PressReleases_FactSheets/PROD01_004906 (noting that specific areas of cooperation include agricultural biotechnology, natural resource management, dairy production and processing, food safety, agricultural product processing, biofuels research and development, and water-saving agricultural technology).

276 See Gary H. Jefferson, RED and Innovation in China: Has China Begun Its SET Takeoff? (Aug. 11, 2004) (unpublished manuscript) available at http:/ / people.brandeis.edu/ jefferso/HCR,\%20August\%2011,\%2004a.pdf (discussing rapid acceleration in R\&D intensity).

277 See Huaiwen He \& Ping Zhang, Impact of the Intellectual Property System on Economic Growth, WIPO-JPO-UNU Joint Research Project 7 (2007), available at http://www.wipo.int/about-ip/en/studies/pdf/wipo_unu_07_china.pdf (discussing how research and development expenditures increased with expanded sales revenue). 
the investor of the overall legal and institutional environment. ${ }^{278}$ Thus, the perceived level of protection in pharmaceuticals influences other industries, because the issuance of a compulsory license for a pharmaceutical product may negatively impact a decision to conduct research and development activities in other industries, particularly in other patent-sensitive industries. The Chinese pharmaceutical industry remains less innovative, and grows less rapidly, than other patent-sensitive sectors of the Chinese industries such as the semiconductor and biotechnology industry. ${ }^{279}$ The issuance of a compulsory license in pharmaceuticals could not only further delay the development of the pharmaceutical sector, but also that of other sectors.

Clear evidence of this phenomenon can be observed in the example of the North China Pharmaceutical Group Corporation ("NCPC"), China's leading pharmaceutical exporter. ${ }^{280}$ Indeed NCPC has been increasing the number of its patent filings with China's State Intellectual Property Office ("SIPO"). However, even in the peak year 2005, its filings numbered less than twenty. ${ }^{281}$ In view of that fact, China has adopted what Professor Peter Yu refers to as a "schizophrenic" nationwide intellectual property policy. Accordingly, China seeks stronger intellectual property protection in areas such as entertainment, software, semiconductors, and selected areas of biotechnology, while striving for weaker protection in less dynamic fields such as pharmaceuticals, chemicals, fertilizers, seeds, and foodstuffs. ${ }^{282}$ This policy means that in the case of

278 See, e.g., A.T. Kearney, New Concerns in an Uncertain World: The 2007 A.T. Kearney Foreign Direct Investment Confidence Index, THE GLOBAL Bus. POL'y COUNCIL 7 (2008), available at http://www.atkearney.com/images/global/pdf/FDICI 2007.pdf (noting that investor concerns over China's investment environment include intellectual property, political and legal environment, and economic stability).

279 See, e.g., Peter K. Yu, International Enclosure, the Regime Complex, and Intellectual Property Schizophrenia, 2007 MicH. ST. L. REV. 1, 25-26 (2007) (noting that China is more likely to prefer strong intellectual property rights in its fast growing industries such as semiconductors and biotechnology than slower growth industries such as pharmaceuticals).

280 He \& Zhang, supra note 277 , at 9.

281 See id. (describing the low number of NCPC's patent filings in China).

282 See Yu, supra note 279, at 25 (discussing China's intellectual property policies). 
[Vol. 32:1

China, Tier-2 sanctions costs for issuance of compulsory licenses over pharmaceuticals cross over to other sectors of its economy.

\subsection{The LBP Model: A Positional Bargaining Situation}

\subsubsection{Introduction}

A third category of developing countries is defined herein as the Low Bargaining Power countries. As a generalization, the LBP model maintains that every developing country, other than Newly Industrialized Countries, is an LBP (per Table 2 above, the 'Default List Countries'). This category logically includes the group of Least Developed Countries, which are the fifty poorest countries in the world, but includes many others as well, bringing the number of countries in the group of LBPs to over one hundred. Similar to the abovementioned HBP and MBP categories, the LBP categorization reflects a shift from market size approximation to a conceptualization of a more complex bargaining situation. The LBP model indicates that the market size approximation fails to describe the true bargaining situation in the post-WTO era. Instead of defining developing countries along the lines of 'market power,' the real narrative of TRIPS, instead, sets the stage for a novel developing country categorization.

The LBP model makes a dual claim. First, it contends that the over one hundred countries in this group possess low bargaining power in terms of their ability to issue compulsory licenses. That is to say, that they have a low outside option in price negotiations with pharmaceutical patentees. Second, the LBP model suggests that the group of LBP countries also has low bargaining power in trade disputes more broadly. This second claim represents, in fact, a partial conceptual shift in comparison to the MPB and the HBP models above. The LBP model contains not only a specific analysis of the relative abilities of the countries within this category to issue compulsory licenses, but also a discussion of bargaining power in trade disputes more broadly. In fact, this second claim - namely that LBPs have low bargaining power more generally, not only in terms of their power to issue compulsory licenses - serves the purpose of illuminating the practical significance of the LeastDeveloped-Country carve-out contained in the TRIPS and other WTO agreements. This analysis shows that the LDC carve-out is too narrow and does not cover a large enough group of countries. More generally, the LBP model will reveal that the distributive jus- 
tice policies contained in TRIPS should be geared towards a broader group of countries.

In international trade, the usual assumption is that low levels of bargaining power are markedly the feature of LDCs. The United Nations officially designates the poorest fifty countries in the world as LDCs. ${ }^{283}$ LDCs are defined by three basic macroeconomic parameters. ${ }^{284}$ These parameters include: a low-income criterion; 285 a human capital status criterion, involving a composite Human Assets Index ("HAI");286 and an economic vulnerability criterion entailing a composite Economic Vulnerability Index ("EVI"). ${ }^{287}$ To be added to the list, a country must satisfy all three criteria. Since the definition of the LDC category recognizes the existence of structural handicaps, it excludes large economies. Thus, to be designated an LDC, the country's population must not exceed seventy-five million. ${ }^{288}$ For the poorest countries, WTO agreements and TRIPS in particular contain some corrective and distributive justice policies, despite being largely procedural in nature.

In fact, the post-WTO era, with its two-tiered bargaining situation, demands the creation of a novel category of countries to in-

283 See Least-Developed Countries, WORLD TRADE ORG., http://www.wto.org /english/theWTO_e/whatis_e/tif_e/org7_e.htm (listing the thirty-two LDCs which are WTO members) (last visited Oct. 7, 2010) (showing who the current members are); U.N. OfFICE OF THE HIGH REPRESENTATIVE FOR THE LEAST DeV. COUNTRIES, The LeAst Developed COUNTRIES: THINGS to KNOW, THINGS to Do 1, 2 (2009), http://www.unohrlls.org/UserFiles/File/LDC\%20Documents/Advocacy $\%$ 20brochure\%20english\%20for\%20web.pdf (discussing the criteria for designation as an LDC).

284 There are two market power-based ways to become eligible for graduation. First, a country's "[GNI] per capita must exceed twice the threshold level," and the "likelihood that the level of [GNI] per capita is sustainable must be deemed high." U.N. OfFICE OF THE HigH REPRESENTATIVE FOR THE LEAST DeV. COUNTRIES, supra note 286 , at 3 . Second, "a country must reach the threshold levels for graduation on at least two of the aforementioned three criteria. ..." Id.

285 This is based on a three-year average estimate of the GNI per capita (under $\$ 745$ for inclusion, above $\$ 900$ for graduation). Id. at 2 .

286 This is based on indicators of: (a) nutrition; (b) health; (c) education; and (d) adult literacy rate. See id.

287 This is based on indicators of: (a) population size; (b) remoteness; (c) merchandise export concentration; (d) share of agriculture, forestry and fisheries in gross domestic product; (e) homelessness owing to natural disasters; (f) instability of agricultural production; and (g) instability of exports of goods and services. See id.

288 Id. at 3. 
clude both LDCs and the remaining non-NIC developing countries alike. All of these countries arguably have little or no bargaining power in negotiations over patented goods, such as drugs, and thus, should be jointly modeled as Low-Bargaining-Power countries, or LBPs. As this part of the article explains, a lack of bargaining power is also what facilitates a distinct form of bargaining policy on the part of developed countries toward the group of LBPs, namely 'positional bargaining.' This form of bargaining is premised on a unilateral offer of stringent intellectual property laws as a package deal. In addition, as a policy concern, existing TRIPS laws favoring LDCs as the poorest countries conceivably represent a discrepancy vis-à-vis the remaining LBPs. This differential approach is clearly demonstrated within the 2005 Hong Kong declaration, which arguably discriminated against most LBPs such as countries in Central and South America, Lower Asia and poorer Eastern European countries.

\subsubsection{Least Developed Countries and Beyond}

Neither the Agreement Establishing the WTO nor the TRIPS Agreement formally categorize Least-Developed-Countries, ${ }^{289}$ or for that matter any other particular group of developing countries. Instead, these agreements merely use declaratory language in indistinctive reference to LDCs' individual development, 290 their "financial and trade needs," 291 or "their administrative and institutional capabilities." 292 Thus, the WTO is noteworthy for voluntary listing LDCs. ${ }^{293}$

289 The world's forty-nine poorest countries are currently designated as LDCs. See Least Developed Countries, United NATIONS OfFICE OF THE High REPRESENTATIVE OF LEAST DEVELOPED COUNTRIES, http://www.unohrlls .org/en/ldc/25/(last viewed Aug. 26, 2009) (listing the least developed countries across the globe); TRIPS Agreement, supra note 16.

290 See Marrakesh Agreement Establishing the World Trade Organization, art. XI(2), Apr. 15, 1994, 1867 U.N.T.S. 154 [hereinafter Marrakesh Agreement] ("The least-developed countries recognized as such by the United Nations will only be required to undertake commitments and concessions to the extent consistent with their individual development, financial and trade needs or their administrative and institutional capabilities.").

291 Id.

$292 \mathrm{Id}$

293 The least developed countries that are members to the WTO are: Angola, Bangladesh, Benin, Burkina Faso, Burundi, Cambodia, Central African Republic, 
From a customary public international legal viewpoint, the WTO's definitions of LDCs most likely did not establish customary law within international intellectual property law. As a political phenomenon, however, it should be noted that beginning in the early 1960s, LDCs did set up a forum in the United Nations from which to proclaim their views and, in doing so, further challenged the packaged deals offered by the developed countries. From 1962 through the mid-1970s, in particular, the United Nations General Assembly - dominated by LDCs - passed a series of resolutions intended to emphasize the sovereignty of nations with respect to foreign investment. Even though "General Assembly resolutions do not represent authoritative statements of international law, they are probative of the state of international law." 294 This is true, particularly given their ever-changing legal nature with reference to foreign investment. ${ }^{295}$

Present-day WTO agreements merely recognize that this loosely theorized group of poor countries must benefit from the greatest possible flexibility and leniency. Consequently, WTO agreements commonly uphold the position that better-off members must make extra efforts to lower import barriers on LDCs' exports. Since the end of the Uruguay Round agreements in 1994, several decisions in

Chad, Democratic Republic of the Congo, Djibouti, Gambia, Guinea, Guinea Bissau, Haiti, Lesotho, Madagascar, Malawi, Maldives, Mali, Mauritania, Mozambique, Myanmar, Nepal, Niger, Rwanda, Senegal, Sierra Leone, Solomon Islands, Tanzania, Togo, Uganda, and Zambia. See Understanding the WTO - Least Developed Countries, WORLD TRADE ORGANIZATION, http://www.wto.org/english /thewto_e/whatis_e/tif_e/org7_e.htm (last visited Aug. 26, 2009).

294 Andrew T. Guzman, Why LDCs Sign Treaties that Hurt Them: Explaining the Popularity of Bilateral Investment Treaties, 38 VA. J. INT'L L. 639, 648 (1998). See, e.g., Texaco Overseas Petroleum Co. v. Libya, 17 I.L.M. 1, 30 (Int'l Arbitral Trib. 1978) ("Resolution 1803 (XVII) seems to this Tribunal to reflect the state of customary law existing in this field."). See also Committee on Int'1 Trade and Investment, The Protection of Private Property Invested Abroad, 1963 A.B.A. SECTION INT'L AND COMP. L. 18 ("The General Assembly is not an international legislature, and its pronouncements are not law, although they may constitute evidence of customary or generally recognized law in the absence of vocal protests by disapproving members.").

295 See, e.g., Guzman, supra note 294, at 648 (noting that the United Nations General Assembly "passed a series of resolutions intended to emphasize the sovereignty of nations with respect to foreign investments", and the difficulty in "claim[ing] customary international law status for norms that are repeatedly contradicted" by such resolutions). 
[Vol. 32:1

favor of LDCs have been taken. To begin with, the WTO ministers agreed on a "Plan of Action for Least-Developed Countries" at a meeting in Singapore in 1996.296 Second, a year later, in October 1997, six international organizations - the International Monetary Fund, the International Trade Centre, the United Nations Conference for Trade and Development, the United Nations Development Program, the World Bank, and the WTO - launched the "Integrated Framework," a joint technical assistance program designed exclusively for least-developed countries. ${ }^{297}$ Third, in 2002, the WTO further adopted a work program for leastdeveloped countries. ${ }^{298}$ Again, under the post-WTO market size approximation, the work program contained several broad policies that erroneously chose to focus solely on LDCs. Logically, these policies ranged from improved market access to increased technical assistance, such as providing support for agencies working on the diversification of least-developed countries' economies or a speedier membership process for LDCs negotiating to join the WTO. ${ }^{299}$

More particularly, using similarly broad declaratory language, the TRIPS Agreement employs a general rule for all developing countries. All Member States are held to the same international minimum standards of protection and enforcement. ${ }^{300}$ TRIPS does offer some form of equitable action toward LDCs alone, but it does so arguably unequally toward other LBPs, such as in Central and South America, Lower Asia and poorer Eastern European countries. 301

Thus, TRIPS favors LDCs, albeit procedurally, in three ways. First, it allows both developing countries and countries-in-

296 See Understanding the WTO: Developing Countries, WORLD TRADE ORG., http://www.wto.org/english/thewto_e/whatis_e/tif_e/dev1_e .htm (last visited Aug. 25, 2009) (highlighting the WTO's special focus on creating agreements that are favorable to the needs of least-developed countries, such as the "Plan of Action for Least-Developed Countries").

297 Id.

298 Id.

299 Id. In addition to the several formal decisions in favor of LDCs, a growing number of governments have unilaterally abandoned import duties and import quotas on all exports from LDCs. Id.

300 See TRIPS Agreement, supra note 16, art. 1 (noting that general principles and provisions apply equally to developing and least-developed countries).

301 See id. art. 66-67 (explaining the special circumstances of LDC members). 
transition ${ }^{302}$ (referring mainly to former Soviet Bloc countries which were closed to FDI until approximately 1990) a five-year grace period within which to fulfill their obligations. ${ }^{303}$ The TRIPS Agreement recognizes technical adjustments that may further delay full compliance with the patent provisions for another five years. ${ }^{304}$ As for LDCs alone, however, TRIPS stipulates a ten-year period of immunity from the duty to implement its substantive or procedural standards.

Second, TRIPS endows its Council with the power to "accord extensions" of the initial ten-year grace period, upon a "duly motivated" request by an LDC member. In doing so, the agreement recognizes their "special needs and requirements" but only in a broad sense. 305 LDCs continue to compete over intellectual property-based foreign trade in even terms with countries with much higher gross national products (GNP), especially the NICs. ${ }^{306}$ Third, developing countries were flatly labeled in reference to the

302 Transition economies within Article 65(3) of the TRIPS Agreement are countries in Central and Eastern Europe that formed part of the former Soviet bloc. The TRIPS Agreement refers to them as "member[s] which [are] in the process of transformation from a centrally-planned [economy] into a market, freeenterprise economy and which [are] undertaking structural reform of [their] intellectual property systems ...." Id. art. 65(3).

303 See id. art. 65(2) (stating that, in addition to the general one year period of delay awarded to all member states, developing countries are entitled to an additional four year delay).

304 See id. art. 70(8), (9) (outlining the procedures that Member states must take in extending patent protection beyond the general guidelines).

305 The TRIPS Agreement notes:

[i]n view of the special needs and requirements of least-developed country Members, their economic, financial and administrative constraints, and their need for flexibility to create a viable technological base, such Members shall not be required to apply the provisions of this Agreement ... for a period of 10 years from the date of application ....

See id.; see also J.H. Reichman, Compliance with the TRIPS Agreement: Introduction to a Scholarly Debate, 29 VAND. J. TRANSNAT'L L. 363, 373 (1996) (noting that the TRIPS Agreement creates a two-tiered approach to distinguish between the obligations of developing countries and least-developing countries).

306 See Simon Lester, The Asian Newly Industrialized Countries to Graduate From Europe's GSP Tariffs, 36 HARV. INT'L L.J. 220, 230 (1995) (arguing that although "preferential tariffs have the potential to help poor countries industrialize and increase their level of economic development . . . [they] are forced to compete on even terms with countries that have GNP per capita levels up to fifty times higher than their own levels"). 
topic of technological transfer, with a suggestive mode of differentiation vis-à-vis LDCs. The drafters of Article 66 of TRIPS described the "special needs and requirements" of these countries identically. ${ }^{307}$ Preceding drafts of Article 66 and 67 do not point toward any major changes during the drafting stages, suggesting that LDCs were for all time granted a number of exemptions in adhering to TRIPS. 308

This kind of affirmative action toward LDCs seems to have given rise to a misguided perception of the kind of bargaining that involves developing countries and the pharmaceutical industry. On the one hand, bargaining with the group of non-LDC developing countries is thought to generate integrative bargains. ${ }^{309}$ The notion of integrative bargains refers to the potential for the parties' interests to be combined in ways that create joint value or enlarge the pie. ${ }^{310}$ Potential for integration only exists when there are multiple issues involved in the negotiation. ${ }^{311}$ Integrative bargains also assume the presence of some bargaining power. ${ }^{312}$ Thus, international patent negotiations are viewed as exchanges between traditional manufactured goods and agricultural products for codified obligations to respect intellectual property rights. ${ }^{313}$ This paradigm has in fact represented the common political science narrative of

307 TRIPS Agreement, supra note 16, art. 66(1).

308 See GERVAIS, supra note 20, at 215 (noting that the Brussels Draft is "essentially identical" to the final act).

309 See David A. Lax and James K. Sebenius, Interests: The Measure of Negotiation in Negotiation THEORY AND PRACTICE 165 (J. William Breslin \& Jeffrey Z. Rubin eds., 1991).

$310 \mathrm{Id}$.

311 Id.

312 See JonAthan SACKS, The POlitics of Hope 198-09 (1997); RoberT AXELROD, THE EVOLUTION OF COOPERATION 3-24 (1984) (discussing the reasons why cooperation emerges among groups); $i d$. at 73-105 (presenting cooperation case studies within World War I and in biological systems).

313 See, e.g., Abbott, supra note 159, at 387-89 (noting that the TRIPS Agreement was part of a "package bargain" that included an agreement by the industrialized countries to reduce levels of agriculture export subsidies in exchange for the developing countries acceptance); Reichman \& Lange, supra note 146, at 15-17 (arguing that while the "package deal" of offering agricultural products for greater access to traditional manufactured goods makes economic sense from a longterm perspective, the higher standards of international intellectual property protection will compel developing and least-developing countries to be noncooperative and resistant to the TRIPS Agreement). 
WTO bargaining at large. On the other hand, for LDCs a more benevolent form of 'Positional Bargains' - a "take it or leave it" kind of agreement - is said to be in place. ${ }^{314}$

\subsubsection{Positional Bargaining Over TRIPS}

In reality, the developed world adopted what is known as positional bargaining in negotiating the international intellectual property framework with the group of LBP countries. In bargaining theory, positional bargaining is a negotiation strategy that involves holding on to a fixed idea, or position, of what one wants and advocating for it and it alone, regardless of the underlying interests. ${ }^{315}$ Each negotiator begins with an extreme position and proceeds from there to negotiate and make concessions. Eventually, a compromise may be reached on dividing the bargain surplus. The WTO's Uruguay Round of multilateral trade negotiations succeeded where prior WIPO's negotiations independent of the international economic framework failed, particularly regarding developing countries. ${ }^{316}$ That success can be explained in that TRIPS was presented as an economic package deal, or what Professor Donald Harris calls "a treaty of adhesion." 317 Such a dynamic has in fact described the bargaining situation with most non-LDCs developing countries, such as in Central and South America, lower Asia and poorer Eastern European countries. ${ }^{318}$ And LBPs, at

314 See Roger Fisher \& William Ury, Getting to Yes: Negotiating AgreEMENT WiTHOUT GIVING IN 4-5 (2d ed. 1981) (discussing the concept of positional bargaining and suggesting that it impedes negotiations).

315 Id.

316 See, e.g., Ruth L. Gana, The Myth of Development, The Progress of Rights: Human Rights to Intellectual Property and Development, 18 LAW \& POL'Y 315, 334 (1996) (arguing that developing countries bear the brunt of the TRIPS Agreement's higher standards and, through the potential threat of ostracism, were forced to accept its exploiting terms); Donald P. Harris, Carrying a Good Joke Too Far: TRIPS and Treaties of Adhesion, 27 U. PA. J. INT'L ECON. L. 681, 724-25 (2006) (arguing that the TRIPS Agreement was a treaty of adhesions because it was "accomplished through a flawed bargaining process where developed countries coerced developing countries into adopting the treaty").

317 Harris, supra note 316 , at 724 .

318 See id. at 725 ("There is no question that at the TRIPS negotiations unequal bargaining power existed between the developing and developed countries."). 
large, could not and did not resist this positional bargaining game. 319

The Uruguay Round and the TRIPS' bargaining game in particular remarkably and similarly 'offered' LDCs, as well as nonLDC LBPs, greater access to markets for traditionally manufactured goods and agricultural products. This offer has come in exchange for stiff codified obligations to respect the intellectual property rights of the technology-exporting countries. ${ }^{320}$ That being said, the "United States has been pushing since the 1994 Summit of the Americas in Miami for a hemisphere-wide free trade zone and asking that developing countries in Central and South America eliminate their own barriers, while being able to maintain its own protectionist measures." 321 Frederick Abbott lists the Uruguay Round bargaining chips employed as including: the reduction of subsidies for agriculture in industrialized nations, concessions with respect to imports of tropical products, the phasing out of quotas of textile products, substantial transition periods, incentives to transfer technology and compulsory licensing. ${ }^{322}$

Positional bargaining is not only practiced vis-à-vis LDCs. It is also the systematic practice used by the developed world in negotiations with non-LDC LBPs. As already alluded to, the products derived from plant genetic biodiversity, to mention a chief intellectual property case for LBPs, are major sources of wealth generation for developed countries. ${ }^{323}$ The International Union for the Protec-

319 See generally Helfer, supra note 118, at 3-4 (noting that nongovernmental organizations are challenging the "moral, political, and economic legitimacy" of TRIPS, focusing on the "power-based bargaining strategies" used by developed countries to coerce developing countries into such an agreement); Abbott, supra note 159, at 387-89 (arguing that the TRIPS Agreement appears to be a bargain between developed and developing countries, but the threat of more restricted access to major industrialized markets induced developing countries to accept the treaty); Abbot, supra note 178, at 691-92 (noting that, in the face of resistance from developing countries, the United States has "threatened and imposed coercive measures on countries it regards as not providing adequate [intellectual property] protection).

320 See Reichman \& Lange, supra note 146 , at 17.

321 See Ormachea, supra note 215, at 139 (highlighting Brazilian led-resistance to the U.S.'s trade strategy due to the United States' unwillingness to eliminate or reduce its barriers to agriculture competition).

322 See generally Abbott, supra note 159, at 387-88.

323 See Chetan Gulati, Note, The "Tragedy of The Commons" in Plant Genetic Resources: The Need for a New International Regime Centered Around an International Bio- 
tion of New Varieties of Plants ("UPOV") establishes the plant variety protection ("PVP") framework known as the Plant Breeders' Rights ("PBRs") regime for UPOV member states. ${ }^{324}$ Originally established by leading developed countries with a head start in plant breeding and agricultural biotechnology, PVP is pivotal to food security in indigenous and local communities. 325 UPOV's legalization of private ownership of and proprietary interest in plant varieties stands for a major transition into the commercialization based on MNEs investment in R\&D in developed countries within bioagriculture and plant genetics. ${ }^{326}$

Thus, LBPs in which most of the plant genetics are housed only collect the rents from the consumption plant genetic resources. ${ }^{327}$ While developed countries are critical about LBPs for their destruction of biodiversity, they are also the principal cause for the inter-

technology Patent Office, 4 Yale Hum. RTs. \& DeV. L.J. 63, 63-64 (2001) (observing that there is significant value in plant genetic resources in a world where "the strategy of wealth maximization has shifted from the desire to accumulate physical property to one in which the domination of intellectual property rights has become preeminent").

324 Id. at 74

325 See Bongo Adi, Intellectual Property Rights in Biotechnology and the Fate of Poor Farmers' Agriculture, 9 J. WORLD INTELl. PROP. 91, 104-07 (2006) (noting that the TRIPS Agreements standards for UPOV are "skewed against developing countries [and were] intended to reward plant breeders and did not recognize farmer's rights or community rights"). For research projects within the food security field, see Indigenous Peoples \& Food Security, CENTRE FOR STUDIES IN FOOD SECURITY, RYERSON UNIVERSITY, http://www.ryerson.ca/foodsecurity/projects /indigenous/index.html.

326 See Chidi Oguamanam, Genetic Use Restriction (or Terminator) Technologies (GURTs) in Agricultural Biotechnology: The Limits of Technological Alternatives to Intellectual Property, 4 CAN. J.L. \& TECH. 59, 60-62 (2005) (noting that today's plant variety protection regime creates "asymmetrical contractual paradigm" where breeders' rights outweigh farmers' rights); see also FOOD AND AGRICULTURE ORG., TRACKING RESULTS IN AGRICULTURE AND RURAL DEVELOPMENT IN LESS-THAN-IDEAL CONDITIONS: A SOURCEBOOK OF INDICATORS FOR MONITORING AND EVALUATION 1 (2008), available at http://www.fao.org/docrep/011/i0380e/i0380e00.htm (discussing monitoring and evaluating agriculture and rural development in developing and least-developing countries).

327 See Oguamanam, supra note 326, at 61 (noting that the uniform transnational plant variety protection regime addressed the need of developed countries such as the United States and European states to impose limits on the rights of users or buyers of protected seed in order to facilitate their profitable seed trade). 
national regime in which this destruction is the most attractive economic option available to LBPs. ${ }^{328}$

Bilateral agreements over agriculture in LBPs, more widely, run into problems with the United States' indisposition to lower agriculture protection. "[C]oncerns have been raised about impoverished corn farmers in Mexico and rice farmers in Honduras and Haiti being driven to other employment because of America's subsidized products." 329

Rationally, an increase in imports unconstructively impacts domestic production. Although reducing or eliminating agriculture protections is particularly imperative for rural Latin American LBPs, the United States has not been flexible on the matter. ${ }^{330}$

Thus, LBPs in which most of the plant genetics are housed only collect the rents from the consumption plant genetic resources. While developed countries are critical about LBPs for their destruction of biodiversity, they are also the principal cause for the international regime in which this destruction is the most attractive economic option available to LBPs. Argentina, Kazakhstan, and Pakistan, three secondary regional powers that are non-LDCs LBPs, illustrate this proposition well.

Argentina's lack of adequate and effective intellectual property protection has caused some friction in its bilateral trade relationship [with the United States]. Argentina has been on the Special 301 Priority Watch List since 1996. . . . In April 2002, negotiations between the governments of the United States and Argentina clarified aspects of Argentina's intellectual property system, such as provisions related to the patentability of microorganisms and its import restriction regime. 331

$328 I d$.

329 See Ormachea, supra note 215, at 150 (arguing that the United States' hopes to create a free trade zone through the FTAA has gone unrealized because of its unwillingness to eliminate its barriers to agricultural subsidies).

330 Id.

331 Office of the U.S. Trade Representative, The 2007 National Trade ESTIMATE REPORT ON FOREIGN TRADE BARRIERS: ARGENTINA (2007), available at http://www.ustr.gov/Document_Library/Reports_Publications/2007/2007_NT E_Report/Section_Index.html [hereinafter, NTE-ARGENTINA]. 
Yet Argentina's amendment of its patent law in December 2003, as required by the May 2002 agreement between the two governments, still did not lead to its removal from the Special 301 Priority Watch List. ${ }^{332}$ What may explain Argentina's LBP-like bargaining situation is its close alignment with the United States in the area of agricultural biotechnology, including as cocomplainants in a WTO dispute challenging the EU moratorium on transgenic crops and its implementation of the Cartagena Protocol of Biosafety. ${ }^{333}$

Kazakhstan is a second case of a non-LDC LBP with which positional bargaining is practiced. "The government's effort to diversify the economy away from the energy sector and spur the growth of a domestic technology-based industry, along with the WTO accession process, has led to a strong emphasis on intellectual property rights protection." 334 Kazakhstan, however, has been unsuccessful in achieving bilateral trade agreements with a number of developed countries, including the United States, the European Union and Australia.335 Not surprisingly, for the last thirteen years, since January 29, 1996, Kazakhstan has been unsuccessful in negotiating membership in the WTO, it being also a non-LDC LBP and also a TRIPS transitory country. 336

A third case exemplifying positional bargaining negotiations with a non-LDC LBP is Pakistan. "The United States placed Pakistan on the Special 301 Watch List from 1989 to 2003 due to widespread piracy." 337 Continuing IPR violations prompted Pakistan's placement on the Special 301 Priority Watch List in both 2004 and

332 Id.

333 Id.

334 Id.

335 Id.

336 See Office of the U.S. Trade Representative, The 2007 National Trade EstiMATE REPORT ON FOREIGN TRADE BARRIERS: KAZAKHSTAN (2007), available at http://www.ustr.gov/Document_Library/Reports_Publications/2007/2007_NT E_Report/Section_Index.html [hereinafter NTE- KAZAKHSTAN] (noting that Kazakhstan is engaged in ongoing negotiations with WTO members and that despite the progress that was made in 2006 it still faces many challenges to implementing WTO-consistent legislation).

337 Office of the U.S. Trade Representative, The 2007 National Trade ESTIMATE REPORT ON FOREIGN TRADE BARRIERS: PAKISTAN (2007), available at http://www.ustr.gov/Document_Library/Reports_Publications/2007/2007_NT E_Report/Section_Index.html [hereinafter NTE-PAKISTAN]. 
2005.338 These Tier-1 sanction costs were left in place even after a twofold Pax-American intellectual property reform. First, Pakistan enacted a patent law in the year 2000 that protects both process patents and product patents in accordance with its WTO obligations. 339 Second, after August 2005, the United States noticeably led threats of sanction against Pakistan. These threats were posed in response to Pakistan's lack of central intellectual property rights regulatory and enforcement authority as well as Pakistan's failure to implement its obligations under TRIPS. In fear of these threats, Pakistan's president created the Intellectual Property Organization of Pakistan, an independent body under the administrative power of the Government's Cabinet Division, which "consolidates into one body the authority over trademarks, patents, and copyrights areas that were until that time handled by three separate ministries." 340

To conclude, the effectiveness of the TRIPS positional bargaining situation vis-à-vis LBPs may be understood twofold. First, this positional bargaining situation allowed LBPs to have greater access to global markets. ${ }^{341}$ Second, through the packaging/collective signing of TRIPS, LBPs presumably avoided unilateral actions by developed countries. ${ }^{342}$ Oftentimes, in theory as in practice, compromises do not satisfy the true interests of the disputants; ${ }^{343}$ instead, they simply split the difference between two positions, giving each side a part of what was sought. Creative, integrative solutions, on the other hand, hold the potential to provide everyone with all of what they desire. ${ }^{344}$ Positional bargaining is

338 Id.

339 Id.

340 Id.

341 See Arie Reich, The WTO As a Law-Harmonizing Institution, 25 U. PA. J. INT'L ECON. L. 321, 362 (2004) (discussing the trade-offs faced when deciding whether to agree to WTO policies); see also Gregory Shaffer, Power, Governance, and the WTO: A Comparative Institutional Approach, in POWER IN GLOBAL GOVERNANCE 130, 130 (Michael Barnett \& Raymond Duvall eds., 2005) (asserting that the United States and the European Union predominate in economic relations because of their considerable resources).

342 See, e.g., CORREA, supra note 27.

343 Reichman \& Lange, supra note 146, at 17 (arguing that the main premise underlying TRIPS' positional bargaining reflects the interests of high-tech producers at the expense of technology-importers). Such is the case with most, if not all, LBPs.

344 FISHER \& URY, supra note 314, at 148. 
thought to be practiced only vis-à-vis LDCs in the post-WTO era. In reality, however, this strict bargaining approach is practiced widely with a much larger group of developing countries, namely the non-LDCs LBPs.

In international patent bargaining, arguably, a much larger group of developing countries - namely non-LDC LBPs - should be regarded as possessing low bargaining power over intellectual property-based technologies such as drugs or plant genetics. In light of that perspective, the distinction between LDCs and nonLDCs developing countries must be qualified as obsolete insofar as bargaining over patents is concerned. In bargaining terms, there is little room to argue that LDCs hold weaker bargaining power than other poor non-LDC LBPs, such as South American, lower Asian or even some of the poorest Eastern European countries. This proposition can be illustrated by the three elements of bargaining power: market power, outside option, and inside options.

\subsubsection{Outside Option}

The first explanation for LBPs' low bargaining power relates to their low outside option value. ${ }^{345}$ In theory, the issuance of a compulsory license could serve as an outside option at the Tier-2 bargain level, when bargaining with the industry and MNEs in particular. It is the case, however, that within the post-TRIPS regime, LBPs' Tier-2 outside option value is particularly limited. This reality is the result of two main factors, deriving from LBPs' short-run and long run low payoffs for the issuance of compulsory licenses.

To begin with, as a short-run or static efficiency concern, LBPs may see low payoffs in pursuing their outside option of purchasing generic drugs from HBPs, such as India or China. As India and China move to adopt a TRIPS-compliant patent regime, LBPs increasingly face difficulties in conducting parallel imports of drugs from generics producers. The TRIPS Agreement sets forth detailed rules that are to be followed by a WTO member nation willing to

345 See MuthOO, BARGAINING THEORY, supra note 93, at 99-100 (providing an overview of bargaining situations with outside options and offering one bargaining solution); see also Abhinay Muthoo, On the Strategic Role of Outside Options in Bilateral Bargaining, 43 OPERATIONS RES. 292 (1995) (exploring a bargaining model in which two opponents are allowed to leave negotiations and return at a later time; concluding that the equilibrium position of the outcome is not affected by the option to leave negotiations and return). 
issue a compulsory license. ${ }^{346}$ It outlines the prerequisites of patentability and the circumstances under which a nation can issue such a license. The TRIPS Agreement, as explained above, does not speak specifically to the issue of compulsory licensing between member nations. ${ }^{347}$ This point is crucial for LBPs with no generics manufacturing capacity of their own, which primarily rely on the infrastructure of MBPs - India and China - or of developed countries to get hold of essential medicines.

In response to this set of concerns, at a WTO meeting in 2001, held in Doha, Qatar, the WTO adopted a Declaration on TRIPS and Public Health. ${ }^{348}$ Government officials have interpreted Paragraph 6 of the declaration to constitute an exception to the TRIPS Agreement, whereby a country that does not have the capacity to produce its own generic drugs in the face of a public health crisis may obtain the necessary drugs from a country that does have such capacity. ${ }^{349}$ By early 2005, the leading supplier of low-cost generic AIDS medicine was India. ${ }^{350}$ As India attempted to attain TRIPScompliance, many health agencies stressed that the days of lowcost treatments for millions of poor patients around the world were ending. ${ }^{351}$ At the close of 2004, it appeared that the Indian government was drafting legislation that would extend beyond the basic TRIPS requirements and consequently endanger access to me-

\footnotetext{
346 See TRIPS Agreement, supra note 16, at Annex 1C, art. 8(1).

347 Id.

348 See Ministerial Declaration of 14 November 2001, WORLD TRADE ORGANIZATION, WT/MIN(01)/DEC/2; 41 I.L.M. 746 (2002), available at http://www.wto.org/english/thewto_e/minist_e/min01_e/mindecl_e.htm [hereinafter Doha Declaration] (providing the text of the Doha Declaration on the TRIPS Agreement and Public Health).

349 The WTO Ministerial Declaration on the TRIPS Agreement and Public Health stated that "the TRIPS Agreement can and should be interpreted and implemented in a manner supportive of WTO Members' right to protect public health and, in particular, to promote access to medicines for all." Id.

350 Editorial, AIDS Drugs Threatened, N.Y. TIMES, Mar. 5, 2005, at A1, available at http://www.nytimes.com/2005/03/05/opinion/05sat3.html?_r=2\&scp=1\&sq $=\% 22$ AIDS $\% 20$ drugs $\% 20$ threatened $\% 22 \& s t=$ cse .

351 See Press Release, Médecins Sans Frontières, The Beginning of the End of Affordable Generics (Mar. 22, 2005), available at http://www.msf.org / msfinternational $/$ invoke.cfm?component=pressrelease\&objectid=4735CF15E018-0C72-09099A512392C0F3\&method=full_html (stating that India's revision of its patent laws, to include protection for medicines, will increase the costs of medicines).
} 
dicines for many poor patients--including by eliminating opportunities for compulsory licensing for LBPs. ${ }^{352}$ Numerous NGOs and health officials around the world urged the Indian government, in this leading case, not to disregard the Doha meeting interpretation of TRIPS.353 India ultimately adopted TRIPScompliant legislation that largely preserves its ability to furnish generics to developing countries.

A second explanation for LBPs' low outside option payoffs derives from their absent long-run innovation-based industries. There is increasing evidence that the weight of R\&D on productivity depends heavily on size of the economy. 354 This dynamic tends to hinder small-economy countries from overcoming their structural underdevelopment through a strategy of investing in R\&D.355 Currently, LBPs and notably Sub-Saharan Africa have access to crucial ARV drugs because most of the ARVs produced in India

352 See Letter from Jim Yong Kim, HIV/AIDS Director, World Health Org., to Dr. A. Ramadoss, Minister of Health and Family Welfare of India (Dec. 17, 2004), www.cptech.org/ip/health/c/india/who12172004.html (last visited Aug. 25. 2009) (urging the Indian government to interpret the TRIPS Agreement in a manner that would protect public health in light of the states' concerns that low cost antiviral drugs from India may not be available to them for long).

353 See Letter from U.N. Special Envoys for HIV/AIDS to the Prime Minister and President of India, Amendments to the Patents Act Under Debate (Mar. 11, 2005), www.cptech.org/ip/health/c/india/unaids03112005.html (urging the Indian government to be flexible in interpreting the TRIPS Agreement in order to ensure that millions worldwide can continue to rely on generic medicines from India); see also Letter from Achmat Dangor, Director of Advocacy, Commc'n and Leadership for UNAIDS, to Kamal Nath, Minister of Commerce and Indus. of India (Feb. 23, 2005), www.cptech.org/ip/health/c/india/unaids02232005.html (last visited Aug. 25. 2009) (urging the Indian government to reject legislative proposals to amend its 1970 Indian Patents Act beyond commitments it made to the WTO because the new proposals will affect millions of people's access to generic HIV medications).

354 See Hulya Ulku, RED, Innovation, and Economic Growth: An Empirical Analysis (Int'1 Monetary Fund, Working Paper No. WP/04/185, Sept. 2004), available at http://imf.org/external/pubs/ft/wp/2004/wp04185.pdf (arguing that while innovation has a positive effect on per capita output everywhere, market size is an important factor in determining the effectiveness of R\&D sectors; accordingly, only larger market OECD countries are able to increase their innovation by investing in $\mathrm{R} \& \mathrm{D}$, and smaller OECD countries promote innovation by using the know-how of other OECD countries).

355 Id. 
and other developing countries are off-patent. 356 Since HIV/AIDS constantly mutates, scientists must continuously develop new treatments, based on future innovation. ${ }^{357}$ While barriers exist in the creation of effective ARVs for certain parts of Sub-Saharan African where there is rampant HIV/AIDS, the concern about the Indian Patents Act and other TRIPS-related laws is also related to long-run payoff. These concerns derive from the need for new innovative technology and the possibility that HBPs like India will innovate and produce new technology to be used by patients in LBPs. ${ }^{358}$ Furthermore, this long-run concern is relevant primarily to 'neglected diseases,' or diseases of the developing world, and particularly LBPs outside LDCs, such as malaria or tuberculosis. Besides HIV/AIDS, these neglected diseases have been virtually eliminated from the innovation agenda in HBPs and developed countries alike. ${ }^{359}$ Yet, they are still rampant in LBPs in Lower Asia, Central and South America, and even poorer parts of Eastern Europe. ${ }^{360}$ As of today, it seems that the new Indian law would greatly hinder the ability of Indian firms to sustain an on-going in-

356 See Press Release, Press Info. Bureau, Gov't of India, Kernel Nath's Statement on the Ordinance Relating to Patents (Third) Amendment (Dec. 29, 2004), available at http://pib.nic.in/release/release.asp?relid=6074\%20\&\%20lists .essential.org/pipermail/ip-health/\%202004-December/007318.html (stating that currently ninety seven percent of all drugs manufactured in India are off patent).

357 See WHO Report on Global Surveillance of Epidemic-prone Infectious Diseases, WORLD HEALTH ORG. (2000), available at http://www.who.int/csr/resources/CSR _ISR_2000_1hiv/en (discussing how HIV/AIDS mutates).

358 See Randeep Ramesh, Cheap AIDS Drugs Under Threat, THE GuARDIAN (UK), Mar. 23, 2005, at A2 (quoting Ellen't Hoen: “But without the Indian drugs industry, where will they get cheap drugs from?").

359 See, e.g., Letter from U.N. Special Envoys for HIV/AIDS, to the Prime Minister and President of India, On the Amendments to the Patents Act Under Debate (Mar. 11, 2005), www.cptech.org/ip/health/c/india / unaids03112005.html (last visited Oct. 15, 2010) (urging the Indian government to carefully consider the affect that the President's Patent Ordinance will have on the millions of people needing cheap HIV/AIDS drugs); see also Understanding The WTO: The Agreements, Intellectual Property: Protection And Enforcement, WORLD TRADE ORG., www.wto.org/english/thewto_e/whatis_e/tif_e/agrm7_e.htm (last visited Aug. 25,2009 ) [hereinafter Understanding The WTO] (explaining the history and purpose of international intellectual property agreements); see also Ramesh, supra note 358.

360 See Understanding the WTO, supra note 359 (explaining the history and purpose of international intellectual property agreements). 
novative policy regarding low-cost medicines for LBPs' neglected diseases.

\subsubsection{Inside Option}

The second explanation for LBPs' low bargaining power in trade negotiations relates to the latter's low value inside options. ${ }^{361}$ TRIPS ignores the small differences in bargaining power over compulsory licenses between LDCs and non-LDC LBPs, and it does so while undermining the latter's inside option cost structure. The present reasoning does not eliminate the production costs or the problems associated with distribution and the timely administration of medicines within this group of non-LDC LBPs. 362 However, this argument implies low inside option cost considerations for most or all LBPs, on three grounds.

First, the Tier-1 inter-governmental bargain level entails a disturbing institutional constraint within TRIPS, again discriminating against non-LDC LBPs by law. Shortly before the WTO Ministerial Conference in Hong Kong, on December 6, 2005, WTO member states agreed to accept a protocol amendment to TRIPS. 363 This amendment sought to provide a permanent solution to implement paragraph six of the Doha Declaration on the TRIPS Agreement and Public Health. ${ }^{364}$ If ratified, the new article 31bis of the TRIPS Agreement will allow countries with insufficient or no manufactur-

361 See, e.g., MUTHOO, BARGAINING THEORY, supra note 93, at 137-38 (explaining that a seller's inside option is the value the seller obtains while the parties temporarily disagree).

362 See, e.g., Amir Attaran \& Lee Gillespie-White, Do Patents for Antiretroviral Drugs Constrain Access to AIDS Treatment in Africa?, 286 J. AM. MED. Ass'N. 1886, 1886-1906 (2001) (discussing the costs of producing medicines and the costs associated with patent protection of those medicines); see also Srividhya Ragavan, The Jekyll and Hyde Story of International Trade: The Supreme Court in PhRMA v. Walsh and the TRIPS Agreement, 38 U. RICH. L. REV. 777 (2004) (detailing numerous examples of governments taking steps to reduce the cost of medication).

363 See World Trade Organization, Amendment of the TRIPS Agreement, Dec. 8, 2005, WT/L/641 [hereinafter TRIPs Amendment] (accepting the amendment to the TRIPs Agreement).

364 See World Trade Organization, Ministerial Declaration on the TRIPS Agreement and Public Health, If 6, WT/MIN(01)/DEC/2, 41 I.L.M. 755 (2002) (instructing the TRIPS council to find a solution to the underutilization of compulsory licensing in WTO member countries with limited manufacturing capabilities). 
ing capacity to import generic versions of on-patent pharmaceuticals. 365

The Enabling Clause of the Hong Kong Declaration is based on what is officially called the "Decision on Differential and More Favorable Treatment, Reciprocity and Fuller Participation of Developing Countries," which was adopted under GATT in 1979. It enables developed members to grant special and more favorable treatment to some developing countries. The Enabling Clause represents the WTO's legal basis for the Generalized System of Preferences ("GSP"). Under the GSP, developed countries offer nonreciprocal preferential treatment (such as zero or low duties on imports) to products originating in developing countries. Preferencegiving countries unilaterally determine which countries and which products are included in their schemes. Within the Hong Kong Declaration vis-à-vis patent-sensitive industries in developing countries, this Enabling Clause should be considered a classic postWTO legal basis for regional arrangements among developing countries and for the Global System of Trade Preferences ("GSTP”). Under such a scheme, a number of developing countries would exchange trade concessions among themselves.

This post-WTO policy of favoritism toward developing countries, however, has not been applied equally towards non-LDCs regional LBPs organizations, as within Asia, the Caribbean, or South America. In particular, these include the Southern Common Market in Latin America ("MERCOSUR"), ,66 the Common Market

365 Although the initial deadline for ratification was December 1, 2007, the deadline was extended for another two years. William New, TRIPS Council Extends Health Amendment; Targets Poor Nations' Needs, INTELL. Prop. WATCH, Oct. 23, 2007, available at http://www.ip-watch.org/weblog/index.php?p=798 (last visited Oct. 8, 2010). As of this writing, slightly over a quarter of the 151 WTO member states, including the United States, India, Japan, China, and most recently members of the European Communities, have ratified the proposed amendment. See Press Release, World Trade Organization, Countries Accepting Amendment of the TRIPS Agreement (Sept. 17, 2010), available at www.wto.org/english /tratop_e/trips_e/amendment_e.htm (last visited Oct. 8, 2010) (providing a list of countries accepting the TRIPS amendment).

366 MERCOSUR is a Regional Trade Agreement ("RTA") between Argentina, Brazil, Paraguay and Uruguay founded in 1991 by the Treaty of Asunción. This treaty was later amended and updated by the 1994 Treaty of Ouro Preto. Its aim is to promote free trade and the fluid movement of goods, people, and currency. See MERCOSUR, http:/ / www.mercosur.org.uy (last visited Oct. 8, 2010). 
for Eastern and Southern Africa ("COMESA"), 367 and the ASEAN Free Trade Area ("AFTA"). ${ }^{368}$

Thus, to facilitate the supply of essential medicines to countries with insufficient or no manufacturing capacity, as is the case of most LBPs, article 31bis(3) creates a special arrangement for both the affected countries as well as those countries belonging to a regional trade agreement. It does so, however, with implied reference only to the African agreement. ${ }^{369}$ Such an arrangement could have allowed the large group of LBPs ${ }^{370}$ to aggregate their markets to generate the purchasing power needed to render the development of an indigenous generics pharmaceutical industry attractive. 371 It also could have paved the way for the development of regional supply centers, 372 procurement systems, 373 and patent

367 The Common Market for Eastern and Southern Africa is a preferential trading area with nineteen member states stretching from Libya to Zimbabwe. See COMESA, http:/ / www.comesa.int (last visited Oct. 8, 2010).

368 ASEAN Free Trade Area ("AFTA") is a trade bloc agreement by the Association of Southeast Asian Nations supporting local manufacturing in all ASEAN countries. AFTA is composed of the ten countries of ASEAN. See, e.g., John S. Wilson \& Benjamin Taylor, Deeper Integration in ASEAN: Why Transport and Technology Matter for Trade, Trade Issue Brief, THE WORLD BANK, July 2008 (discussing the progress of ASEAN countries resulting from economic integration).

369 See TRIPs Amendment, supra note 363, art. 31bis(3) (creating limited exceptions to article 31(f) for WTO member countries that are parties to a trade agreement in situations where the less developed countries share the same health problem).

370 The TRIPs Agreement distinguishes between developing and least developed countries. This Article uses "less developed countries" to denote both developing and least developed countries. When referring to the TRIPs Agreement, however, this Article returns to the terms "developing countries" and "least developed countries."

371 See Peter K. Yu, The International Enclosure Movement, 82 IND. L.J. 827, 848 (2007) (discussing the crucial conditions for a nation to develop "internally competitive pharmaceutical manufacturers").

372 See Frederick M. Abbott \& Jerome H. Reichman, The Doha Round's Public Health Legacy: Strategies for the Production and Diffusion of Patented Medicines Under the Amended TRIPS Provisions, 10 J. INT'L ECON. L. 921, 973-77 (2007) (discussing "[t]he potential benefits of pooled procurement strategies" and the establishment of regional pharmaceutical supply centers).

373 See Sisule F. Musungu ET AL., UtILIZING TRIPS FleXIBILITIES FOR Public HeAlth Protection Through South-SOUth Regional Framework xv-xvi (South Centre 2004) (advocating the establishment of "regional procurement systems where they would jointly conduct tendering through an entity acting on their behalf and a central purchasing agency managing the purchases on behalf of all the 
pools and institutions, while facilitating technical cooperation within the region. ${ }^{374}$

Unfortunately, because article 31 bis specifically requires that Least Developed Countries make up at least half of the membership of any beneficiary regional trade agreement, the provision would benefit only a limited number of developing countries, predominantly those in Sub-Saharan Africa. ${ }^{375}$ By referring solely to the LDCs classification, the other LBPs countries, such as within Asia, the Caribbean, or South America are once again ignored.

An important example of non-LDC LBPs is presented through the Andean Pact countries, referring to five South American developing countries, namely Venezuela, Ecuador, Peru, Colombia and Bolivia, as well as three other Latin American countries, namely Chile, Mexico, ${ }^{376}$ and Cuba. ${ }^{377}$ Like LDCs, these developing countries often have made a call for solidarity against the efforts by the developed world and the United States to press Andean Pact governments into enacting further amendments to protect intellectual property rights in Latin America. ${ }^{378}$ These non-LDCs countries, la-

member countries"); see also id. at 70-76 (discussing regional procurement systems).

374 See TRIPs Amendment, supra note 363, art. 31bis annex 5 (establishing that the annex to the Agreement "are without prejudice to the rights" of member countries except those rights outlined in paragraphs (f) and (h) of Article 31).

375 See id. art. 31bis(3) (requiring that "at least half of the current membership of [the regional trade agreement] is made up of countries presently on the United Nations list of least developed countries").

376 Mexico, however, is certainly bound by the North American Free Trade Agreement (NAFTA). See North American Free Trade Agreement, Dec. 17, 1992, 32 I.L.M. 289, 670 (1993). Under such agreement, Mexico specifically undertook to protect IPRs under the stringent standards defined in chapter 17 of the agreement.

377 See, e.g., Cuba backs Brazil in AIDS drug patent row, THEPHARMALETTER (Mar. 7, 2001), http://www.thepharmaletter.com/file/13177/cuba-backs-brazil-in-aidsdrug-patent-row.html (last visited Oct. 8, 2010) (describing Cuba's support for allowing Brazil to develop cheaper, generic versions of pharmaceuticals).

378 See, e.g., Andean Pact Call To Fight Us IPR Pressure, THEPHARMALETTER (July 5, 1993), http://www.thepharmaletter.com/file/81906/andean-pact-call-to-fightus-ipr-pressure.html (last visited Oct. 8, 2010) (describing the efforts by Andean Pact countries to resist pressure from the United States to strengthen intellectual property rights in the Andean region). 
beled herein as LBPs, have similarly implemented changes to their patent laws as a result of pressure from the United States. 379

To be sure, foreign trade laws in contexts other than TRIPS often waive and grant various regional national organizations affirmative action-tailored policies, as granted by the General Council of the World Trade Organization. 380 Recent examples of waivers include the EC/France Trading Arrangements with Morocco, ${ }^{381}$ the United States' Caribbean Basin Economic Recovery Act ("CBERA"), ,82 the Canadian Tariff Treatment for Commonwealth Caribbean Countries ("CARIBCAN"), 383 the United States' Andean Trade Preference Act, and the ACP-EC Partnership Agreement. 384

This narrow interpretation of the 31(bis)(3) Hong Kong Declaration provision, interpreted to include solely LDCs, in fact remains challenged within the WTO's pharmaceutical bargaining game. While the European Communities "insisted that the [provision] should be limited to what is effectively sub-Saharan Africa," other LBPs hold a much broader interpretation. ${ }^{385}$ Although these countries may be less poor than the group of LDCs, these remaining LBPs arguably need to be included in the 31bis arrangement, as under the TRIPS regime they are provided remarkably little bargaining power vis-à-vis technology-manufacturing MNEs and foreign governments alike.

The holdout effect by the United States toward all bargaining LBPs as one was evidently observed in numerous international

379 For the Pan-South American stand, see CILFA, at the 15th Assembly of the umbrella organization for Latin American pharmaceutical industries, and ALIFAR in Bariloche, Argentina. See, e.g., North and South Americans Against Patents, THEPHARMALETTER (May 30, 1994), http://www.thepharmaletter .com/file/63017/north-and-south-americans-against-patents.html (last visited Oct. 8, 2010) (discussing the opposition in both North and South America against pressure from the United States to introduce new intellectual property protection in Latin America).

380 Article IX:3 of the WTO Agreement states that such entities may use a notice of planned procurement or a notice regarding a qualification system as an invitation to participate in the deliberations herein.

381 For the specific decisions taken at the 4th Ministerial Meeting, see World Trade Organization, Ministerial Decision of 14 November 2001,WT/MIN(01)/15 (2002).

382 Id.

383 Id.

384 Id.

385 Abbott \& Reichman, supra note 372, at 945. 
trade rounds. The Doha rules of 2001 notably allowed LBPs to break patents to import, but did not authorize them to override patents for the purposes of export to countries in need. In December of 2002 in Geneva, although 143 of the WTO's 144 members agreed on a solution, the lone holdout-the United States-obstructed the agreement. 386 American negotiators lobbied to limit covered medicines to those for HIV / AIDS, malaria, tuberculosis, and a few additional diseases that primarily affect Africa. Other LBPs, as it were, jointly sought a more flexible approach on access to medicines that would allow nations to protect public health as they see fit. ${ }^{387}$ As a result, no agreement was reached by close of the talks. ${ }^{388}$ There perhaps could be a need to relax this rigid LDCs-oriented trade rule by allowing other LBPs to obtain essential medicines at a more affordable cost. 389

Second, low inside option cost considerations remain for LBPs, as there have been only a few reported initiatives on South-South technology transfers with reference to most LBPs alike. ${ }^{390}$ This fact again contributes to the low bargaining power of countries other than LDCs that belong to the LBP category. Certainly, MBPs such as China and India already possessed a manufacturing capacity and therefore are perceived to remain outside the scope of this limited LBPs bargaining power narrative. ${ }^{391}$

386 Jeffrey Sparshott, U.S. Refusal Thwarts WTO Drug-Patent Talks - Bush Seeks Supporters of Interim Plan to Ease Enforcement for Poor Nations, WASH. TIMES, Dec. 25, 2002, at C10.

387 See Editorial, A Global Medicine Deal, N.Y. TIMES, Jan. 5, 2003 (describing the need for a flexible system of medical access).

388 After the fiasco in Geneva, the Bush administration, in balance, pledged not to bring trade pressure against countries that export cheap drugs for HIV/AIDS and other resource-poor country epidemic diseases. Id.

389 This Article describes only the positive theory of bargaining, and does not focus on possible normative ramifications.

390 Joan Rovira, Creating and Promoting Domestic Drug Manufacturing Capacities: A Solution for Developing Countries, in Negotiating Health in Negotiating Health, Negotiating Health: InTEllectual Property AND ACCess to Medicines 227, 235 (2006). There are, however, a few examples for South-South trade worth mentioning. To illustrate, Thailand offered to help Ghana and Zimbabwe to set up factories to produce HIV/ AIDS antiretrovirals. Id. Brazil, in comparison, offered a cooperation agreement, including technology transfer, to developing countries for the production of generic ARV drugs. Ellen 't Hoen, supra note 196, at 32.

391 Council for Trade-Related Aspects of Intellectual Prop. Rights, Communication from Kenya, the Coordinator of the African Group, Elements of a Para- 
Article 66 of the TRIPs Agreement, in particular, requires developed countries to provide incentives for their businesses and institutions to help create "a sound and viable technological base" in Least Developed Countries, realistically referring to other LBPs, by promoting and encouraging transfer of technology. 392 However, it is unclear how these LBPs could enforce Article 66, even with the assistance of the mandatory WTO dispute settlement process. Likewise, "[a]though the Doha Declaration is full of verbal commitments and plans for capacity building, it is silent about how to fund the ambitious technical assistance programs." 393 "Furthermore, its legal nature as a 'work program' is particularly vague," further undermining LBPs' inside option. ${ }^{394}$ With little LBP bargaining power, it was only natural that developed countries, MBPs and HBPs with ARV manufacturing capabilities eventually signed technology transfer agreements with the few LBPs that wished to manufacture generics locally. ${ }^{395}$ LBPs' inside option value further diminish as a result.

The disparity between MBPs and HBPs on the one hand, and LBPs, on the other, was also apparently perceived during the discussion of solutions to implementing paragraph 6 of the Doha Declaration. There, some LBPs underscored the importance of building local manufacturing capacity. ${ }^{396}$ Their demands eventually created tension towards HBPs and MBPs alike. The African Group strived for an explicit agreement proposing the solution of building domestic manufacturing competence. ${ }^{397}$ HBPs and MBPs, like Bra-

graph 6 Solution, IP/C/W/389, I 15(a) (Nov. 14, 2002) (evidencing the belief on the part of the African Group that only long-term solution to paragraph 6 is building up domestic manufacturing capacity).

392 TRIPS Agreement, supra note 16, art. 66(2).

393 Sungjoon Cho, A Bridge Too Far: The Fall of the Fifth WTO Ministerial Conference in Cancún and the Future of Trade Constitution, 7 J. INT'L ECON. L. 219, 226 (2004).

394 Id.

395 See, e.g., UNAIDS, 2004 REPORT ON THE GLOBAL AIDS EPIDEMIC 104 (2004) (discussing efforts to bring local pharmaceutical production to low- and middleincome countries).

396 See Frederick M. Abbott, The WTO Medicines Decision: World Pharmaceutical Trade and the Protection of Public Health, 99 AM. J. INT'L L. 317, 334 (2005) (discussing the desire of some developing countries, especially those in Africa, to increase domestic manufacturing capacity).

397 BHAGWATI, supra note 29. 
zil and India, for their part, already had manufacturing know-how and consequently believed otherwise. ${ }^{398}$

LBPs bear low inside option value in the Tier- 1 bargain for a third and additional reason deriving from the fact that changes in patent laws in MBPs with manufacturing capacity, such as India, further undermined LBPs' inside option. LBPs heavily depend on drug imports from MBPs. ${ }^{399}$ Although LDCs are not obliged under the WTO rules enshrined in the 2001 Doha Declaration to grant or enforce pharmaceutical product patents until at least 2016, other developing countries saw this transition period end in January 2005. This list includes countries with significant manufacturing capacity, such as India, a major source of WHO prequalified generic ARVs. They were required to introduce new pharmaceutical patent legislation in order to comply with WTO rules. This requirement may be viewed to create fundamental bargaining implications for LBPs. Nonetheless, as long as the present LBPs' price crisis is unresolved "it is unclear how these recent or newer drugs may be made available at sustainable and affordable prices in the developing world," further undermining their inside option value. 400

On the Tier-2 bargain level, further evidence for the overall demise of LBPs' inside option may be found. Under the current bargaining situation, access to life-saving medicines, in particular, for the LBPs truly depends on the goodwill of MNEs towards LBPs in tandem. MNEs voluntarily offer their most discounted prices to LBPs including non-LDC LBPs. However, MNEs have little or no economical incentive to do so. 401 In reality, many LBPs' endemic diseases could be prevented or treated with vaccines or pharmaceuticals that are not accessible to the populations in most LBPs. To illustrate, almost 18 million people, mostly in LBPs stretching from Africa to Central or South America, are infected with river blindness (onchocerciasis) which is curable by administering a sin-

398 Id.

399 See Médecins Sans Frontières, Untangling the Web of Price Reductions: A Pricing Guide for the Purchase of ARVs fOR Developing COUNTRIES 7 (10th ed. 2007) (discussing India's role in creating and selling generic antiretroviral medications).

$400 \mathrm{Id}$. at 8 .

401 See id. at 8-9 (discussing the discounts originator companies may provide to LDCs). 
gle oral dose of Ivermectin (trade name B Mectizan) per year. ${ }^{402}$ Moreover, the drugs isoniazid and co-trimoxazloe effectively treat tuberculosis 403 and pneumonia, respectively, but are rarely available to poor people in many LBPs outside sub-African LDCs. ${ }^{404}$ Interventions for these and many other LBPs-based diseases may be more cost effective and entail less risk than for the most expensive HIV therapies emphatically undermining their bargaining power within TRIPS.

\subsubsection{Market Power}

Most LBPs alike have little or no market power when bargaining with MNEs directly. To start, with regard to Tier-1 bargaining with the developed world, and particularly the United States, most if not all LBPs are regulation-takers. As William Lovett notes, "the preferential 'edge' for LDCs and NICs that was built into the original GATT (1947), GATT-Part IV (1965), and various GATT (1979) Codes, such as the Subsidies Code, has not been adequately offset by United States presidential administrations and trade authorities," 405 and "[a] double standard that favors developing nations is implicit in these arrangements." 406 Political developments diminished the authority of existing international bodies in this areasuch as the World Intellectual Property Organization ("WIPO") and the United Nations Economic, Social and Cultural Organization ("UNESCO") - while at the same time inconsistently dismissing GATT's basic purposes and premises. ${ }^{407}$ In the post-World

402 See The Magnitude of River Blindness, THE CARTER CENTER http://www .cartercenter.org/health/river_blindness/index.html (last visited Oct. 21, 2010), for a discussion on the enormous impact of river blindness on endemic countries and how Merck's Mectizan has effectively treated the disease.

403 See Rajesh Gupta et al., Responding to Market Failures in Tuberculosis Control, 293 SCI. 1049, 1049 (2001) (discussing methods to lower costs of anti-tubercular drugs in low-income countries)

404 See Karen Zwi et al., Cheaper Antiretrovirals to Treat AIDS in South Africa: They are at Their Most Cost Effective in Preventing Mother to Child Transmission, 320 BRIT. MED. J. 1551, 1551 (2000) (arguing that the reduction of drug prices is effective, but access to these drugs remain unavailable in certain areas of South Africa).

405 William A. Lovett, Current World Trade Agenda: GATT, Regionalism, and Unresolved Asymmetry Problems, 62 FoRDHAM L. REV. 2001, 2006 (1994).

406 Id. at 2002.

407 See, e.g., Jerome H. Reichman, The TRIPS Component of the GATT's Uruguay Round: Comparative Prospects for Intellectual Property Owners in an Integrated World 
War II era, as Lovett notes: “[T]he United States and United Kingdom were key players in early GATT rounds, and collective sense of responsibility for newly liberated colonies and Latin American nations led them to concede non-reciprocal leeway for more subsidies, protectionism, and multiple exchange rates to less developed countries." 408 Furthermore, "[t]he basic theme of providing unconditional most-favored-nation treatment under Article II strongly favored the interests of weaker and smaller trading nations, [such as] most NICs and LDCs." 409

Today, however, LDCs continue to face substantial asymmetries rooted in the GATT,410 uneven economic development through the International Monetary Fund ("IMF"), ${ }^{411}$ regional discrimination, and divergent industrial policies in the WTO. Whenever LBPs fail to comply with the United States-led policy concerning the issuing of compulsory licensing, American MNEs evenly

Market, 4 FordHAM INTELL. PROP. MEDIA \& ENT. L.J. 171, 179-80 (1993) (assessing the different reactions of developed and developing countries to the TRIPS Agreement).

408 Lovett, supra note 405, at 2005.

409 Id. at 2005 n.12. See also William A. Lovett, Rethinking U.S. Industrial-Trade Policy in the Post-Cold War Era, 1 TUL. J. INT'L \& COMP. L. 135, 139 (1993) (discussing how the broad range of subsidies, preferences, and tariffs granted by GATT fostered two development strategies among FDCs.). The asymmetry problem also has been analyzed extensively in WILLIAM A. LOVETT, WORLD TRADE RIVALRY: TRADE EQUiTY AND COMPETING INDUSTRIAL POLICIES 8-11, 52-53, 75-96, 105-28 (1987). GATT, however, " (at least until 1994) and United States national trade law still allowed considerable leeway for sensible United States adjustments and offsets to foreign subsidies, restrictions, and discounting." Lovett, supra note 405, at 2006. Had the United States used its own GATT and national-law-trade remedies willingly, thereby overcoming local interest groups and other exogenous concerns, "most of the asymmetry problem" for LDCs would have been resolved. Id.

410 As Wesche observes, structural realism would indicate that LDCs' involvement generates significant losses, leading them to refrain from participating unless forced to do so. However, in GATT's Uruguay Round, developing countries did choose to participate. See Lisa M. Wesche, The Impact of Uncertainty on Developing Countries' Decision to Negotiate in Multilateral Institutions, Presented at the 2002 Annual Meeting of the American Political Science Association (Aug. 29-Sept. 1, 2002), available at http://www.allacademic.com/meta /p65528_index.html (examining why the developing countries cooperatively participated in negotiations at the Uruguay Round).

411 See LOVETT, supra note 409, at 38-40 (providing a history on the IMF, the International Bank for Reconstruction and Development, later the World Bank, and GATT). 
pressure their government to issue economic sanctions towards all LBPs alike. ${ }^{412}$

LBPs also have virtually no market power in Tier-2 bargaining with MNEs. In that sense, LBPs are also price-takers. ${ }^{413}$ The primary explanation for this phenomenon is that LBP pharmaceutical consumer markets tend to be small. ${ }^{414}$ Host country market size is one of the most critical factors in attracting foreign direct investment ("FDI"), and is one that places LBPs at a significant disadvantage. ${ }^{415}$ In fact, most pharmaceutical FDI flows to the developed world. ${ }^{416}$ Pharmaceutical MNEs derive their above-average profitability from the continuous release of new drugs. The global market is estimated at approximately USD $\$ 500$ billion, and the leading 12 companies - all of which are headquartered in developed countries - account for approximately $45 \%$ of total sales. ${ }^{417}$

In conclusion, there are three central explanations for LBPs' low bargaining power. The first of the three relates to the fact that LBPs face low outside option payoffs, due to both static and dynamic inefficiencies. LBPs increasingly face difficulties in accessing generic medicines produced in India and China. Additionally, LBP markets provide implied incentives for drug innovation over neglected diseases, particularly in India, which is currently their main supplier. The second explanation for LBPs' low bargaining power involves their limited inside options based on three factors: the existence of a disturbing institutional constraint in the TRIPS Hong Kong Declaration that discriminate against non-LDC LBPs; the limited availability of South-South technology transfers; and

412 See also Jagdish Bhagwati, Aggressive Unilateralism: An Overview, in Aggressive UnILATERAlisM: AMERICA's 301 Trade POLICY AND THE WORLD TRADING SYSTEM 1-4 (Jagdish Bhagwati \& Hugh T. Patrick eds., 1990) (discussing the background and exercise of Section 301 actions by the United States). See generally Shell, supra note 118, at 843-44 (describing the dispute resolution system implemented after the Uruguay Round revisions to GATT).

413 "Price-takers" is a financial term describing parties who are forced to accept whatever price the market sets, and lack the ability to affect or shift the market price. EDNA CAREW, The LANGUAGE OF MONEY 3, at 260-61 (1996).

414 See John Macdonald, The Top Ten and Emerging Pharmaceutical Markets, BUSINESS INSIGHTS, available at http://www.globalbusinessinsights.com/content /rbhc0018m.pdf (last visited, October 21, 2010).

415 LIPPOLDT, supra note 218, at 4-6.

416 Id. at 9.

417 Fórum de Competitividade, supra note 172, at 13. 
the fact that changes in patent laws in countries such as India further undermine LBPs' inside option. Finally, the low bargaining power over compulsory licenses by LBPs is mainly a function of the fact that these countries have very little, if any, market power in price and regulation negotiations with MNEs and their home governments. That is, when it comes to bargaining over international patent regulation and international prices of patented goods, LBPs are by and large both regulation-takers and price-takers.

\section{CONCLUSION}

This article puts forth a positive theory of bargaining power based on the bargaining situation that has developed in the postWTO era. The typology presented is rendered possible by the demise of the pre-WTO bargaining models of MNEs-host developing country relations developed in the 1970s and 1980s. ${ }^{418}$ During the post-WTO era these models have lost their explanatory power, a phenomenon that is particularly evident in negotiations between developing and developed countries over access by the former to medicines produced or developed in the latter. Numerous policy considerations ensue from this Article's analysis.

For a start, lack of innovation carries paradoxical implications for certain developing countries in bargaining over TRIPS policies. A paradigm based on two-tiered and multi-party negotiations arguably stresses the special situation of NICs in this regard. NICs differ from other developing countries in that they possess sizeable and desirable markets, often coupled with an industrial capacity to produce generics. In particular, innovative NICs suffer a paradoxical weakening, rather than boosting, of bargaining power over the prospects of issuing compulsory licenses. This notion explains why non-innovative NICs are modeled as HPBs to denote their higher levels of bargaining power, whereas innovative NICs are modeled as MBPs indicating medium levels of bargaining power. This dynamic is particularly relevant to the case of compulsory licenses, which serves as the working example here.

Furthermore, in highlighting certain specificities within NICs, the positive bargaining theory developed herein deemphasizes the

418 See Ramamurti, supra note 17, at 24-25 (discussing shifts in FDI trends in developing countries, particularly a significant increase in FDI between 1990 and 1998). 
practical relevance of the LDC carve-out contained in the TRIPS Agreement. It does so by considering all non-NICs as lowbargaining power countries, or LBPs. Under the existing state of affairs, access to medicines by the majority of developing countries depends on the goodwill - or perhaps, reputational concerns - of the pharmaceutical industry. The industry, however, bears little economic incentives to promote access in these countries. ${ }^{419}$

A third ramification, as shown above, flows from the argument that the Tier-1 inter-governmental bargaining level entails a reversible institutional favoritism towards LDCs. It thus may be argued that this bargaining situation discriminates against the remaining LBPs, particularly within the 2005 Hong Kong declaration. In attempting to facilitate the supply of essential medicines to countries with insufficient or no manufacturing capacity, as is the case for most LBPs, the proposed Article 31bis(3) to the TRIPS Agreement creates a special arrangement not only for affected countries, but also for those belonging to a regional trade agreement-however the implied reference is only to the African ones. ${ }^{420}$ These LBPs now include numerous Central and South America, Lower Asia or even poor Eastern European countries. Specifically, these regional agreements presently consist of the Southern Common Market in Latin America ("MERCOSUR"), the Common Market for Eastern and Southern Africa ("COMESA"), and the ASEAN Free Trade Area ("AFTA").

Instead, the Hong Kong declaration should have allowed the large group of LBPs ${ }^{421}$ to aggregate their markets to generate the purchasing power needed to make the development of an indigen-

419 See Médecins Sans Frontières, supra note 399, at 9 (arguing that insufficient competition allows prices to remain high for drugs and these prices only fall as a result of public pressure or generic competition).

420 General Council, Amendment of the TRIPS Agreement, WT/L/641 (Dec. 8, 2005), available at www.wto.org/english/tratop_e/trips_e/wtl641_e.htm [hereinafter TRIPS Agreement Amendment].

421 The TRIPs Agreement distinguishes between developing and least developed countries. This Article uses "less developed countries" to denote both developing and least developed countries. When referring to the TRIPs Agreement, however, this Article returns to the terms "developing countries" and "least developed countries." 
ous pharmaceutical industry attractive. ${ }^{422}$ It also should have paved the way for the development of regional supply centers, ${ }^{423}$ procurement systems, ${ }^{424}$ and patent pools and institutions, while simultaneously facilitating technical cooperation within the region. ${ }^{425}$ If ratified, the new Article 31bis of the TRIPs Agreement will allow countries with little or no manufacturing capacity to import generic versions of on-patent pharmaceuticals. 426

Beyond these three policy ramifications, it must be noted that there exist several constraints on this Article's model. First, and regrettably, by virtue of being a situational model, it does not-and cannot - reflect the long-run dynamic efficiency implications of the post-WTO regime. While the developed countries' emphasis on the protection of intellectual property rights has been heavily criticized as a "'beggar thy neighbor' approach," 427 the TRIPS Agreement could be read to reflect a static economics efficiency of the structure of intellectual property, and particularly patent law. This Article, therefore, does not address whether-or how-the TRIPS Agreement could be read for long-run efficiency, thereby allowing adjustments in national intellectual property regimes designed to reflect their specific innovative growth dynamics. ${ }^{428}$ An

422 But see $\mathrm{Yu}$, supra note 371 , at 848 (discussing how there is no guarantee that aggregated LDC markets generating enough impetus for significant development of an indigenous pharmaceutical industry).

423 Abbott \& Reichman, supra note 372, at 973-77 (discussing the potential benefits of pooled procurement strategies and the establishment of regional pharmaceutical supply centers).

424 MusUNGU et al., supra note 373.

425 TRIPS Amendment, supra note 363, art. 31bis.

426 Although the initial deadline for ratification was December 1, 2007, the WTO granted a two-year extension. William New, TRIPS Council Extends Health Amendment; Targets Poor Nations' Needs, InTEll. Prop. WATch (Oct. 23. 2007), www.ip-watch.org/weblog/index.php?p=798.

427 Frederick M. Abbott, The Enduring Enigma of TRIPs: A Challenge for the World Economic System, 1 J. INT'L ECON. L. 497, 521 (1998).

428 There is noticeably important evidence suggesting that, at least in the United States, patent rights over research opportunities have begun to hinder long-run efficiency by chilling innovation. See, e.g., Rebecca S. Eisenberg, Bargaining over the Transfer of Proprietary Research Tools: Is This Market Failing or Emerging?, in EXPANDING THE BOUNDARIES OF INTELLECTUAL PROPERTY: INNOVATION POLICY FOR THE KNOWLEDGE SOCIETY 223 (Rochelle Dreyfuss et al. eds., 2001) (indicating that in some cases, patent rights have stifled research by increasing transaction costs); Carlos M. Correa, Internationalization of the Patent System and New Technologies, 20 
explanation for the present model's short-run focus lies within innovation theory. All things being equal, patents affect efficiency by spurring innovation while generating a deadweight loss. Furthermore, it is well understood that the first effect is positive and dynamic, while the second is negative and static. 429 TRIPS, on the other hand, hinders the ability of policymakers to choose a protection level that strikes the right balance between the dynamic efficiency gain and the static efficiency loss. This is particularly so given the developmental inequality among HBPs, MBPs and LBPs, which is demonstrably relevant.

It may be contended, based on the present positive model, that strong protection for intellectual property rights may have significant negative allocative consequences in developing countries without contributing to-and in fact even impeding - their technological development. ${ }^{430}$ Thus, the HBP-MBP-LBP underlying developmental inequality shifts the balance between static and dynamic efficiencies, such that short-term access and affordability to innovative-based goods takes priority over long-term innovation policy goals where necessary.431 As Joseph Stieglitz notes in his article "Knowledge as a Global Public Good": "The gain in dynamic efficiency from the greater innovative activity is intended to balance out the losses from static inefficiency from the underutilization of the knowledge or from the underproduction of the good protected by the patent." 432 In the case of health care, the goods protected by the patent are the pharmaceuticals. The article's model thus leaves TRIPS' lawmakers to achieve merely a contextual policy of balancing minimum standards with flexibilities in the short-

WIS. INT'L L.J. 523, 528 (2002) (stating that patents create tension within the economy by creating barriers to entry and increasing litigation costs).

429 Joseph E. Stiglitz, Knowledge as a Global Public Good, in GLOBAL Public GOODS: INTERNATIONAL COOPERATION IN THE 21st CENTURY 308, 311 (Inge Kaul et al. eds., 1999); Gideon Parchomovsky \& Peter Siegelman, Towards an Integrated Theory of Intellectual Property, 88 VA. L. REV. 1455, 1458-60 (2002).

430 Carlos M. Correa, Managing the Provision of Knowledge: The Design of Intellectual Property Laws, in PROVIDING Global PubliC GoOds: MANAGING Globalization 410, 414 (Inge Kaul et al. eds., 2003).

431 Stiglitz, supra note 429 , at 311.

432 Id. at 311. 
run, among HBPs and LBPs as non-innovative developing countries, and among MBPs as well. ${ }^{433}$

This article's modest static innovative hypothesis is also acutely relevant to, as Michael Mireles notes: "[The ongoing] debate [of] the merits of the Bayh-Dole Act, which allows recipients of government funding to take title of inventions developed with that funding, and its purported consequences since the Act's inception." 434

The adoption of the Act in non-innovative developing countries, namely HBPs and LBPs, however, could lead to an increased focus on commercializing technology directed toward the local needs of developing countries. Regrettably, the result of equal enactment of such legislation in these developing countries may prove unlikely to have the same purported dynamic innovative impact on a similar scale to that which the Bayh-Dole Act supposedly had in the United States. ${ }^{435}$

433 But see Claudia Chamas et al., Current Issues of IP Management in Health and Agriculture in Brazil, in INTEllectuAl PROPERTY MANAGEMENT IN HEALTH AND Agricultural InNOVATION: A HANDBOOK OF BEST PRACTICES 1563 (Anatole Krattiger et al. eds., 2007) (arguing that Brazil should strengthen IP laws in order to maximize innovation and technological development).

434 Michael S. Mireles, The Bayh-Dole Act and Incentives for the Commercialization of Government-Funded Invention in Developing Countries, 76 UMKC L. REv. 525, 526 (2007). See generally University and Small Business Patent Procedures Act, 35 U.S.C. §§ 200-212 (2006) (outlining the scope, policy, and objectives of the BayhDoyle Act)

435 See Chris Bull, Managing Intellectual Assets at Universities: The South African Government is Considering the Introduction of Legislation Similar to the US Bayh-Dole Act Governing Intellectual Property Arising from University RED, MANAGING INTELL. PROP. (Apr. 1, 2005), available at http://business.highbeam.com/435489/article1G1-132162379/managing-intellectual-assets-universities-south-african (reporting South Africa's decision to consider drafting legislation similar to the Bayh-Dole Act); Should SA Follow US Lead on Patent Laws?, AFRICA NEWS, Jan. 13, 2004 (reporting on the South African Government's drafting of legislation similar to the BayhDoyle Act). 